\title{
VISUALIZAÇÃO NO ENSINO DE QUÍMICA: APONTAMENTOS PARA A PESQUISA E DESENVOLVIMENTO DE RECURSOS EDUCACIONAIS
}

Leila Cardoso Teruya e Guilherme Andrade Marson*

Departamento de Química Fundamental, Instituto de Química, Universidade de São Paulo, Av. Prof. Lineu Prestes, 748, 05508-000 São Paulo - SP, Brasil

Celeste Rodrigues Ferreira e Agnaldo Arroio

Departamento de Metodologia do Ensino e Educação Comparada, Faculdade de Educação, Universidade de São Paulo, Av. da Universidade, 308, 05508-040 São Paulo - SP, Brasil

Recebido em 11/4/12; aceito em 12/11/12; publicado na web em 18/2/13

\begin{abstract}
VISUALIZATION IN CHEMISTRY EDUCATION: DIRECTIONS FOR RESEARCH AND DEVELOPMENT OF EDUCATIONAL RESOURCES. Visualization is a fast-growing field in science education. This review covers 171 articles published between 2001 and 2010 in 14 science education journals. Major findings include: i - despite the predominance of English speaking countries, interest in the topic has increased in several countries; ii - qualitative research is increasing, but quantitative methodologies prevail; iii - the role of peer interaction in group activities is little investigated; iv - research on the way students and teachers use visualization tools is increasing, but most publications focus on the tools; $\mathrm{v}$ - structure of matter remains the most common subject covered.
\end{abstract}

Keywords: visualization; chemical education; educational research.

\section{INTRODUÇÃO}

Dentre os diversos temas contemplados pela pesquisa em ensino de ciência e, especificamente, de química, a visualização tem sido objeto de estudo recorrente, uma vez que pesquisadores da educação e professores de química têm reconhecido a importância do assunto para o ensino dessa ciência. ${ }^{1}$ Há, inclusive, edições especiais dedicadas ao tema, como a edição número 3 (Visual and Spatial Modes in Science Learning) do periódico International Journal of Science Education, publicada em 2009. No período entre 2001 a 2010, o crescente número de estudos dedicados ao tema tornou a pesquisa em visualização no ensino de química consideravelmente mais densa e diversa, ao que se associa formidável volume de informação.

Gobert ${ }^{2}$ afirma que os três usos mais comuns do termo visualização na psicologia e na pesquisa educacional incluem três processos distintos, mas não exclusivos: visualização como representações externas, que se referem a formas de representação com finalidade didática, como gráficos, diagramas, modelos e simulações; visualização como representações internas, definidas como construtos mentais internos ou modelos mentais; e visualização como habilidade espacial, que compreende a habilidade visuoespacial de lidar com informações desse gênero.

Ainda, de acordo com Gilbert, Reiner e Nakhleh, ${ }^{3}$ encontramos na literatura dois significados diferentes para o uso do termo visualização:

- $1^{\text {o }}$ significado: o termo visualização é usado como "verbo", visualizar algo, atuar mentalmente sobre uma representação visual, ou seja, atribuir significado. Nestes trabalhos, discutem-se questões relacionadas com a forma como as representações visuais (internas e externas) transformam-se em conhecimento, quais serão os processos mentais envolvidos na atribuição de significado a uma representação visual. ${ }^{4}$

- $2^{\circ}$ significado: o termo visualização é usado como "nome", algo que foi colocado à disposição de um público, na forma de um objeto material ou virtual. Os estudos que adotam essa convenção analisam

*e-mail: gamarson@iq.usp.br o impacto das representações virtuais, ou o uso combinado de vários tipos de ferramentas visuais na aprendizagem. ${ }^{5}$

Para Gilbert et al., ${ }^{6}$ a visualização está relacionada à formação de uma representação interna a partir de uma representação externa, de tal modo que a essência e as relações temporais e espaciais características da representação externa são retidas. Os autores também defendem que a visualização é fundamental para o ensino de química, considerando a necessidade de se aprender os modelos científicos já estabelecidos e aprender a desenvolver novos modelos de natureza tanto quantitativa quanto qualitativa. Ainda sobre modelos científicos, Justi e Gilbert ${ }^{7}$ lembram que a educação em química requer o aprendizado de modelos, isto é, a formação de representações mentais apropriadas, sem as quais os estudantes podem ter dificuldades de aprendizado.

Estas, segundo Chittleborough e Treagust, ${ }^{8}$ podem ser atribuídas à natureza dual da química, que apresenta tanto as características reais e visíveis do nível macroscópico quanto as reais, mas não tão visíveis, do nível submicroscópico. De acordo com os autores, seria exatamente essa impossibilidade de enxergá-lo, refletida em modelos mentais pobres envolvendo a estrutura da matéria, que tornaria o nível submicroscópico de difícil compreensão para os estudantes.

Considerando que as representações visuais fornecem um meio de tornar visíveis os fenômenos que não podem ser captados por nossa visão ${ }^{9}$ e que a efetividade no ensino de química depende tanto da habilidade do professor em explicar conceitos abstratos e complexos quanto da habilidade dos estudantes em compreender tais explicações, ${ }^{10}$ as representações visuais têm sido empregadas para auxiliar os estudantes a aprenderem conceitos químicos pela construção de seus próprios modelos mentais. ${ }^{1,8}$ A despeito disso, alguns autores ressaltam que o ensino de química e a pesquisa educacional historicamente enfatizaram o aprendizado e a informação verbal, deixando as representações visuais em segundo plano, como se o uso de imagens implicasse a aprendizagem tácita dos conceitos. ${ }^{9,11}$

A relação entre visualização e o ensino de química foi apontada no estudo de Wu e Shah. ${ }^{1}$ Os autores realizaram uma revisão bibliográfica com foco em três aspectos: correlação entre habilidades espaciais e aprendizado de química; erros conceituais e dificuldade 
de se entender representações visuais; e ferramentas de visualização desenvolvidas para superação dessas limitações. Os resultados da pesquisa mostraram uma correlação positiva entre êxito no aprendizado de química e melhores habilidades visuoespaciais, além do fato de que muitos dos erros conceituais apresentados pelos estudantes são decorrentes da falta de entendimento adequado das representações visuais. Entretanto, tais representações invariavelmente acabam se restringindo a determinados aspectos dos conceitos e princípios estudados, ${ }^{11}$ o que exige dos estudantes habilidades visuoespaciais para visualizar aquilo que não está explícito na representação original. Essa dificuldade é bastante recorrente quando é cobrada dos estudantes, por exemplo, a visualização tridimensional de moléculas que estão representadas bidimensionalmente em livros didáticos. ${ }^{12}$

Em relação às habilidades de visualização, Costa et al. ${ }^{13}$ alertam para o fato de que os alunos apresentam níveis de literacia visual diferentes, de modo que podem interpretar aquilo que veem de diversas maneiras.

Schonborn e Anderson ${ }^{14}$ complementam que são poucas as instituições de ensino que explicitamente ensinam essas habilidades aos alunos, uma vez que é comum a suposição errônea de que as mesmas, assim como outras habilidades cognitivas, podem ser adquiridas automaticamente, pela simples realização de algumas atividades que exigem visualização ou pelo uso de ferramentas de visualização. Esta situação deve-se muito provavelmente à pouca importância dada, ainda, ao uso destas ferramentas nos cursos de formação inicial, tal como constataram Ferreira e Arroio, ${ }^{15}$ e, por conseguinte, a uma formação superficial e pouco sólida nesta área.

Apesar da elevada importância que vários autores atribuem ao uso de visualizações, no sentido de estas auxiliarem os alunos a construírem os seus próprios modelos mentais, Kozma e Russell ${ }^{16}$ atribuem às representações visuais um papel importante dentro da perspectiva da Teoria Situativa. ${ }^{17}$ De acordo com estes autores, é através destas representações que os químicos conseguem visualizar, discutir e compreender objetos e processos que não estão presentes ou não são visíveis numa dada situação. Na sala de aula, a presença destes recursos permitiria aos alunos interagirem entre si à medida que se engajam nas atividades propostas pelo professor, criando, segundo essa teoria, uma comunidade de práticas. Sendo assim, as representações visuais seriam úteis para construir e comunicar conhecimento, e serviriam para encorajar os alunos a formularem e avaliarem hipóteses, construírem argumentos e conclusões.

Marson e Torres ${ }^{18}$ lembram ainda que o uso de recursos de visualização pode contribuir para o melhor entendimento, entre os estudantes, dos diferentes níveis de representação da química e como os mesmos se integram.

Em vista da importância da visualização no ensino de química e da crescente produção acadêmica na área observada na década de 2001 a 2010, o presente estudo teve como objetivo atender à necessidade de se identificar tendências, sistematizar conceitos e propor direções investigativas para a pesquisa em visualização no ensino de química. ${ }^{19}$ Para tanto, neste trabalho é apresentado o produto da análise de estudos publicados em periódicos relevantes da área de ensino de ciências.

Megid Neto e Pacheco ${ }^{20}$ e Haddad ${ }^{21}$ caracterizam esse tipo de pesquisa como um campo de estudo que analisa, num recorte temporal definido, as características da evolução histórica, tendências temáticas, metodológicas, os principais resultados das investigações, problemas e limitações que devem ser objeto de análise em relação às produções acadêmicas em uma determinada área de pesquisa.

$\mathrm{Na}$ área do ensino de química, Schnetzler ${ }^{22}$ realizou uma revisão abrangendo o período de 1977 a 2001. A autora traçou um panorama da pesquisa em ensino de química no Brasil a partir do levantamento e análise de artigos publicados em Química Nova e Química Nova na Escola, resumos de teses e dissertações sobre o assunto, além de resumos publicados nas Reuniões Anuais da Sociedade Brasileira de Química (SBQ). Seguindo linha de pesquisa semelhante, Francisco e Queiroz ${ }^{23}$ concentraram sua revisão em resumos na área de ensino apresentados nas Reuniões Anuais da SBQ entre 1999 e 2006.

\section{METODOLOGIA DE PESQUISA}

Foram selecionados e analisados 171 artigos publicados entre 2001 e 2010

\section{Seleção de artigos para o estudo}

Os artigos foram selecionados individualmente em três etapas:

1) seleção por periódico - os seguintes periódicos foram escolhidos, dada sua ampla circulação e reconhecida qualidade na área da pesquisa educacional: Journal of Chemical Education (J. Chem. Educ.), Biochemistry and Molecular Biology Education (BAMBED), Research in Science Education (Res. Sci. Educ.), Science \& Education (Sci. Edu.), Chemical Education Research and Practice (Chem. Educ. Res. Pract.), Computers \& Education (Comput. Educ.), Journal of Research in Science Teaching (J. Res. Sci. Teach.), International Journal of Science Education (Int. J. Sci. Educ.), Problems of Education in 21 st century (PEC), Revista Electronica de Enseñanza de las Ciencias (REEC), Journal of Science Education and Technology (J. Sci. Educ. Technol.), Revista Brasileira de Pesquisa em Ensino de Ciências (RBPEC), Química Nova (Quim. Nova), Química Nova na Escola (QNESC);

2) seleção por análise dos títulos e palavras-chave - número a número, os periódicos indicados na $1^{\mathrm{a}}$ etapa foram consultados, identificando-se artigos cujos títulos sugerissem conteúdos relevantes para este estudo. Adicionalmente, empregou-se a busca por termos tais quais 'visualização', 'habilidades visuoespaciais' e 'literacia visual' (e os correspondentes em língua inglesa) no descritor de palavras-chave dos artigos;

3) seleção por resumos - os resumos dos artigos cujos títulos ou palavras-chave foram considerados de interesse foram então analisados a fim de se confirmar se tais trabalhos de fato se relacionavam ao tema desta pesquisa. Em caso positivo, o artigo em si foi analisado e, confirmado seu enquadramento no escopo deste estudo, classificado em descritores.

Tal procedimento baseia-se nas premissas de que, conforme indica Severino (p. 62): ${ }^{24}$ os títulos "devem dar a ideia a mais exata possível do conteúdo do setor que intitulam"; e que os resumos, em princípio, facilitam a divulgação dos trabalhos produzidos na esfera acadêmica com mais abrangência. ${ }^{25}$

\section{Classificação dos artigos selecionados}

Os artigos assim selecionados foram classificados de acordo com os seguintes descritores:

1. país de origem do autor principal - refere-se ao país da instituição de filiação do primeiro autor e não, necessariamente, à nacionalidade do mesmo;

2. tipo de artigo - inclui as categorias 'investigação' (identificam-se uma pergunta e a condução da pesquisa para abordá-la), 'metodologia de ensino' (proposição de alternativas metodológicas com foco na visualização), 'recurso didático' (relatos de novos recursos didáticos, sem indicação de avaliação ou vinculação à investigação) e 'revisão';

3. conceitos químicos - para maior facilidade do tratamento e interpretação dos dados, os inúmeros conceitos citados foram reunidos em 7 grupos mais frequentes: 'estrutura da matéria' 
(ex.: ligação química, estrutura atômica, natureza particulada da matéria), 'propriedades moleculares' (ex.: interações intermoleculares, simetria, isomeria), 'bioquímica' (ex.: proteínas, ácidos nucleicos, transporte celular), 'físico-química' (ex.: equilíbrio químico, cinética, eletroquímica), 'química geral' (ex.: estequiometria, reações, substâncias simples e compostas), 'técnicas de laboratório’ (ex.: cromatografia, titulação, separação de misturas) e 'outros' (conceitos de menor ocorrência);

4. metodologia usada no contexto educacional - corresponde ao método de trabalho utilizado, no que diz respeito às estratégias de ensino empregadas. Inclui as categorias 'trabalho em grupo', 'trabalho individual', 'aula expositiva', 'laboratório', 'grupo de discussão', 'outros' (metodologias diferentes das citadas) e 'não explicitado' (metodologia não explicitada);

5. metodologia de pesquisa educacional - refere-se ao método de pesquisa selecionado para atender aos objetivos da pesquisa. Abrange as categorias 'análise comparativa de pré e pós-testes', 'questionário para coleta de dados analisados de forma quantitativa', 'questionário para coleta de dados analisados de forma qualitativa', 'avaliação tipo likert', 'análise de desenho', 'gravação em vídeo ou áudio', 'entrevistas livres, estruturadas ou semiestruturadas', 'outros' (metodologias diferentes das citadas) e 'não explicitado' (metodologia não explicitada);

6. meio suporte didático - relacionado ao tipo de recurso didático utilizado no trabalho, contemplando as categorias 'interativo' (programa computacional que oferece ao usuário algum grau de interatividade), 'modelo molecular físico' (de qualquer material), 'animação' (vídeo com animação, sem interatividade, com possibilidades mínimas de controle, como tocar, pausar etc.), 'ilustrativo papel' (ilustrações presentes em livro e qualquer outro material impresso), 'ilustrativo eletrônico' (ilustrações apresentadas em mídia eletrônica) e 'outros' (outros meios suporte diferentes dos citados.).

Os descritores 'conceitos químicos', 'metodologia usada no contexto educacional', 'metodologia de pesquisa educacional' e 'meio suporte didático' admitiam classificação em mais de uma categoria (i.e. duas ou mais metodologias de pesquisa, estudo com dois ou mais tipos de suporte didático). Nesses casos, o número total de categorias no descritor pode ser maior que o número total de artigos analisados.

Os dados obtidos foram compilados em uma planilha eletrônica e analisados em termos da frequência de ocorrência das categorias nos diversos descritores (material suplementar).

\section{RESULTADOS E DISCUSSÃO}

\section{Produção por periódico}

O primeiro critério de classificação analisado foi a produção bibliográfica por periódico. Dentre as revistas pesquisadas, o J. Chem. $E d u c$. é o periódico com mais publicações na área de visualização (77), seguido, na maior parte dos anos, pela BAMBED (21), J. Sci. Educ. Tech. (12) e Chem. Edu. Res. Pract. (11). Cada um dos demais periódicos é responsável por menos de 5\% do total de artigos analisados. O periódico Sci. Educ. apresenta 6 trabalhos. Com igual número de publicações, aparecem as revistas Comput. Educ. e PEC (8), J. Res. Sci. Teach. e Int. J. Sci. Educ. (7), Res. Sci. Educ., REEC e Quim. Nova (4), RBPEC e QNESC (1). A partir desses dados, verifica-se que, considerando os periódicos nacionais, há um total de 6 publicações sobre o tema visualização.

Os quatro periódicos com maior número de publicações sobre visualização também apresentam os maiores números de publicações gerais, dentre os periódicos pesquisados. Um ponto interessante a discutir é o destaque da $B A M B E D$, uma revista voltada para a área de educação em bioquímica e biologia molecular, entre os periódicos com mais artigos sobre o tema.

Como ressaltam Schonborn e Anderson, ${ }^{14}$ é consenso entre bioquímicos a relevância da visualização e das ferramentas de visualização para o entendimento de biociências tanto em nível celular quanto molecular. Apesar dos diferentes tamanhos, esses níveis estão presentes na proposta de Talanquer, ${ }^{26}$ que amplia a ideia de que o conhecimento químico pode ser expresso em três componentes: macroscópico, microscópico e simbólico. ${ }^{27}$ Para Talanquer, o conhecimento químico pode ser de três tipos diferentes: experiência (empírico), modelo (explicativo) e visualização (signos visuais). Ele pode estar compreendido ainda em escalas de tamanho variadas, estando os níveis subatômico e macroscópico em seus extremos. Completando a proposta, o conhecimento químico também poderia ter diferentes dimensões (estrutura/composição, energia e tempo) e ser abordado de formas distintas (matemática, conceitual, contextual e histórica).

Acerca das revistas brasileiras, vale destacar o discreto aumento das publicações sobre visualização nas mesmas, em consonância com o crescente número de resumos na área de pesquisa em ensino de química publicados nas Reuniões Anuais da SBQ ao longo dos anos. ${ }^{22,23}$

\section{Produção por país}

A produção bibliográfica por país da instituição de filiação do primeiro autor a cada ano pode se visualizada na Figura 1.

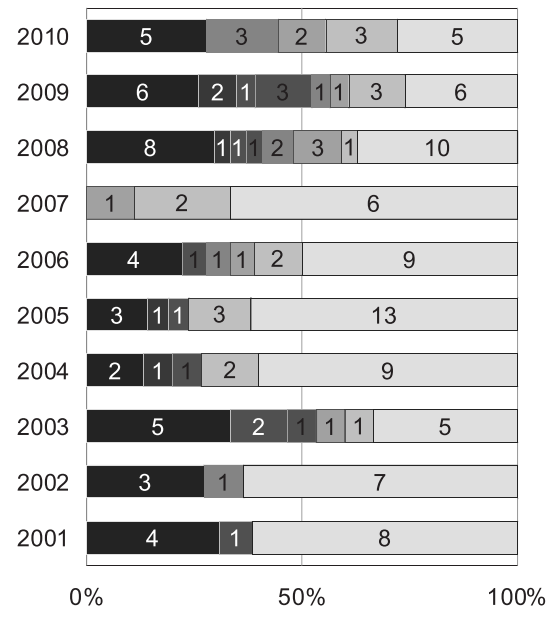

Fração de artigos publicados sobre o total no ano

Outros $\square$ Turquia $\square$ Grécia
$\square$ Austrália $\square$ Inglaterra $\square$ Israel
$\square$ Brasil $\square$ EUA

Figura 1. Produção anual por país de origem da instituição de filiação do primeiro autor. Os dados em barras exprimem para cada ano a produção em termos do \% do total de artigos publicados no ano. Os números nas barras indicam os valores absolutos. Foram considerados os 8 países de produção mais expressiva. A categoria outros inclui os países Canadá, Taiwan, México, Portugal, África do Sul, Espanha e Suíça

Os resultados revelam que os Estados Unidos são o país com maior número de publicações na área de visualização (78), sendo Brasil (17), Israel (9), Reino Unido (8) e Austrália (7) os próximos países que mais contribuem com publicações. Sobre a posição de destaque do Brasil neste levantamento, ressalta-se que a maior parte dos trabalhos (12) não foi publicada em periódicos nacionais, mas sim nos estrangeiros. Salienta-se ainda nestes resultados que, dentre esses cinco países, três têm o inglês como idioma oficial, que é a língua em que se publicam os artigos nos principais periódicos 
internacionais. Este deve ser um fator facilitador para a publicação de artigos para estes países, como hipotetizam Lee et al. ${ }^{28}$ Segundo os autores, os quatro países que mais publicaram entre 2003 e 2007, considerando três diferentes jornais da área de ensino, foram Estados Unidos, Austrália, Reino Unido e Canadá, todos falantes do inglês. Por outro lado, na mesma revisão, foi mostrado que os países em que o inglês não é o idioma oficial têm aumentado suas contribuições na literatura de pesquisa em ensino de ciências. Resultado semelhante foi encontrado no presente estudo, uma vez que a diversidade de países com publicações na área de visualização aumentou nos últimos anos.

\section{Produção por tipo de artigo}

De acordo com a Figura 2, que aponta a produção por tipo de artigo a cada ano, os artigos do tipo recurso didático, que tratam do desenvolvimento e avaliação de recursos didáticos, representam a maior parte dos artigos publicados em quase todo o período, sendo verificado ligeiro declínio nos últimos anos, com aumento também pequeno da participação de artigos do tipo metodologia de ensino, em que aspectos metodológicos do ensino constituem o foco principal da pesquisa.

\section{Produção anual por tipo de artigo}

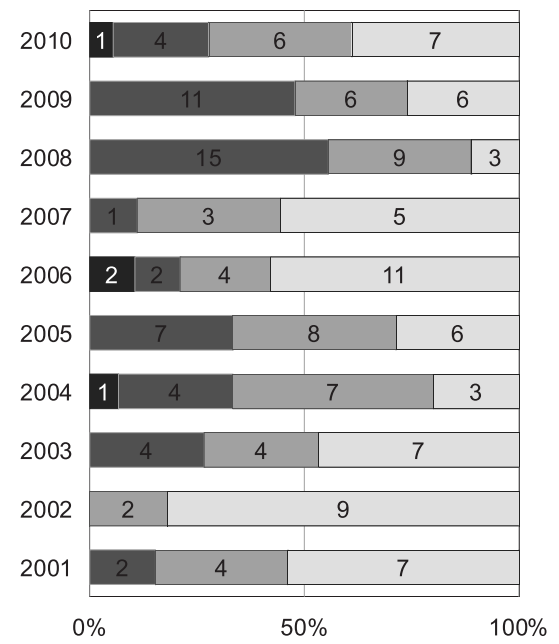

Fração de artigos publicados sobre o total no ano

$$
\square \text { Revisão } \square \text { Investig. } \square \text { Metodol. } \square \text { Didático }
$$

Figura 2. Produção anual por tipo de artigo. Os dados em barras exprimem para cada ano a produção em termos do \% do total de artigos publicados no ano. Os números nas barras indicam os valores absolutos. Foram considerados os 4 tipos de artigos: $i$-Revisão: artigos de revisão; $i i$ - Investig.: artigos de investigação; iii - Metodol.: artigos de metodologia de ensino; iv-Didático: artigos sobre recursos didáticos

Os dados obtidos indicam que os trabalhos de inovações didáticas e metodológicas, portanto, constituíram a maior parcela dos artigos publicados em todos os anos.

Os números encontrados são condizentes, em âmbito nacional, com os apresentados por Francisco e Queiroz. ${ }^{23}$ Segundo levantamento realizado pelas autoras, os trabalhos classificados como de recursos didático e de conteúdo-método foram, em $1^{\circ}$ e $2^{\circ}$ lugares, respectivamente, os mais apresentados nas RASBQ no período de 1999 a 2006. Dessa forma, é plausível que os artigos sobre visualização sigam tendência semelhante, com destaque, no caso, para as ferramentas de visualização.

Wu e Shah ${ }^{1}$ destacam que o grande interesse das pesquisas envolvendo recursos de visualização, que vão desde os modelos físicos até os programas de computador, deve ser atribuído à importância que o raciocínio visuoespacial tem para a química. O uso de visualizações no ensino está imerso em várias correntes teóricas que vão desde as teorias socioculturais até as correntes de base mais internalista, apoiadas pelo forte desenvolvimento da psicologia cognitiva.

De acordo com a Teoria Sociocultural de Vygotsky, ${ }^{29}$ as visualizações podem ser consideradas ferramentas de mediação semiótica, em que sistemas de signos são constantemente utilizados para mediar processos sociais (comunicar, construir conhecimento) e o pensamento. Em uma das suas palestras proferidas em 1930, dá exemplos de algumas destas ferramentas: a linguagem; vários sistemas para contar; técnicas mnemônicas; sistema de símbolos e algébricos; trabalhos sobre arte; escritos; esquemas; diagramas; mapas e desenhos mecânicos; todo tipo de signos convencionais etc. ${ }^{30}$ Esta perspectiva sociocultural propõe-nos que o processo de significação, em sala de aula, seja concebido por uma prática social mediada pelo signo (por exemplo, visualização) e pelo outro (colegas e professores). ${ }^{31}$

Dentro da corrente da psicologia cognitiva, destacam-se a Teoria da Codificação Dual de Allan Paivio, ${ }^{32}$ a Teoria da Carga Cognitiva de John Sweller ${ }^{33}$ e a Teoria de Aprendizagem por Multimídia de Richard Mayer. ${ }^{34}$ Durante os últimos anos, muitos dos softwares e metodologias propostas no campo do ensino de ciências através do uso de ferramentas visuais têm sido inspiradas nestas teorias e no conhecimento atual sobre a arquitetura cognitiva. De acordo com Reed, ${ }^{35}$ a arquitetura cognitiva inclui a descrição dos tipos de memórias de armazenamento de informação (curto e longo prazo), códigos de memória (associações semânticas, imagens visuais etc.) e operações cognitivas.

Embora esta questão seja polêmica, dado que uma representação mental é inacessível aos outros, é também nesta área que encontramos subsídios para compreendermos como representamos internamente informação, ou seja, que tipo de representações internas construímos a partir das representações externas. De acordo com Johnson-Laird, ${ }^{36}$ existem três tipos de representações mentais:

a) representações proposicionais, que são cadeias de símbolos (representações de significados totalmente abstraídas) relacionados por uma determinada sintaxe, verbalmente expressáveis;

b) modelos mentais, que são análogos estruturais de objetos ou eventos que são espacial e temporalmente análogos a impressões sensoriais, mas que podem ser vistos de qualquer ângulo - e aí nos vêm imagens - e que, em geral, não retêm aspectos distintivos de uma dada instância de um objecto ou evento;

c) imagens, que são representações bastante específicas que retêm muitos aspectos perceptivos de determinados objetos ou situações vistas de um ângulo particular. ${ }^{37}$

Dado que o conhecimento químico é inerentemente multimodal e as palavras sozinhas não conseguem expressar todo este conhecimento ${ }^{38}$ vários autores ${ }^{39}$ sugerem que o uso de visualizações adequadas levará à construção de modelos mentais adequados e que, sem estes, a aprendizagem em química se torna muito difícil. No entanto, o enfoque destes trabalhos centra-se, por vezes, na relação entre o sujeito e a ferramenta (visualização), sendo as interações sociais omitidas ou relegadas para segundo plano.

Estes estudos têm causado impacto na comunidade de ensino de química, na qual a necessidade e a proliferação de ferramentas visuais associadas ao uso de tecnologias são muito grandes, como já referido. Professores e educadores, nos seus respectivos contextos, estabelecem uma série de objetivos de aprendizagem para os seus alunos, numa tentativa de serem bem sucedidos; estes professores e educadores recorrem então, cada vez mais, ao uso de ferramentas de visualização.

Apesar do grande número de artigos sobre recursos didáticos e metodologias, observou-se um pequeno aumento relativo dos trabalhos investigativos, sugerindo que mais questões relacionadas 
à visualização em ensino de química têm surgido e despertado o interesse dos pesquisadores.

Dentre as questões levantadas pelos pesquisadores, pode ser citado o efeito da utilização de ferramentas de visualização no aprendizado. Diversos estudos comparam grupos de pesquisa que fizeram uso de determinado recurso de visualização e grupos de controle que tiveram aulas sem o recurso ou com pouca ênfase em visualização, ${ }^{40}$ trazendo, em sua maioria, conclusões favoráveis ao uso das ferramentas de visualização. A comparação entre diferentes modalidades de suporte didático também é objetivo recorrente de muitos estudos, ${ }^{41}$ cujos resultados tendem a associar o melhor aprendizado dos alunos à utilização de ferramentas de visualização mais dinâmicas.

Outra questão relevante é a influência do conhecimento prévio do aluno no aproveitamento dos recursos de visualização. De acordo com Liu et al. ${ }^{42}$ alunos com domínio conceitual prévio de níveis diferentes adotam estratégias distintas quando resolvem problemas que envolvem simulação computacional; além disso, o conhecimento prévio também influenciaria a interação entre os alunos ao resolver os problemas. Ainda sobre o assunto, o estudo de Cook et al..$^{43}$ indica que alunos com melhor entendimento prévio de um conceito dirigem sua atenção visual a aspectos mais relevantes de uma representação visual e têm mais facilidade em coordenar representações micro e macroscópicas para compreender um fenômeno. Cook,${ }^{44}$ por sua vez, afirma que o conhecimento prévio pode influenciar a forma como o aluno percebe e interpreta uma representação visual.

\section{Produção por conceito químico}

Na Figura 3, observa-se a produção por conceitos químicos a cada ano. Apesar da variação irregular ao longo dos anos, é possível notar que estrutura da matéria constitui a classe de conceito mais

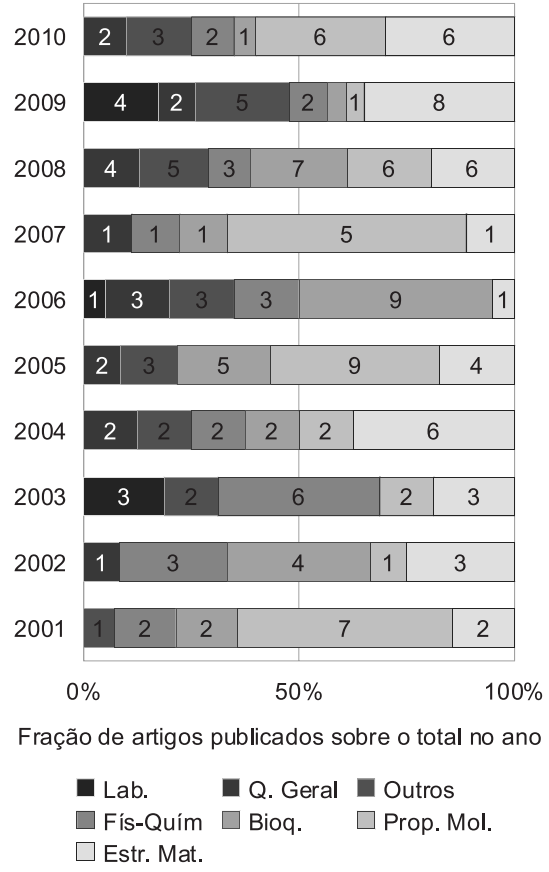

Figura 3. Classificação da produção anual por conceitos químicos tratados nos artigos. Os dados em barras exprimem para cada ano a produção em termos do \% do total de artigos publicados no ano. Os números nas barras indicam os valores absolutos. Os conceitos químicos foram agrupados em grandes categorias: $i$ - Lab.: técnicas de laboratório; ii - Q. Geral: química geral; iii - Outros: categorias de menor ocorrência; iv - Fís-Quím: físico-química; v-Bioq.: bioquímica; vi-Prop. Mol.: propriedades moleculares; vii-Estr. Mat.: estrutura da matéria estudada na área de visualização, seguida de perto por propriedades moleculares.

Este grupo compreende conceitos que estão presentes na maioria dos currículos de todos os níveis de ensino (fundamental, médio e superior), como ligação química, estrutura molecular e natureza particulada da matéria.

A dificuldade de se compreender este último tópico, em particular, é atribuída não apenas à dimensão submicroscópica da matéria, ${ }^{45}$ mas também ao fato de que, para os alunos, não é intuitiva a ideia de que a matéria é constituída por partículas. ${ }^{46}$ Problemas de aprendizagem envolvendo esse conceito podem ser resultado de uma habilidade de visualização pobre, ${ }^{47}$ gerando possíveis concepções alternativas sobre esse modelo de constituição da matéria. ${ }^{48}$ Stern et al. ${ }^{49}$ lembram, ainda, que a compreensão de muitos conceitos importantes da química esbarra na falta de entendimento da natureza particulada da matéria.

Outros tópicos relacionados à estrutura da matéria também são apontados como básicos para o aprendizado de outros conceitos. Deste modo, por exemplo, a habilidade de visualizar estruturas moleculares é considerada essencial para se entender conceitos mais avançados, como análise conformacional, ${ }^{50}$ reatividade $^{51}$ e simetria molecular. ${ }^{52}$

Embora representem conceitos, a priori, mais elementares, dificuldades de ensino relacionadas à estrutura da matéria são verificadas em todos os níveis, o que pode explicar o maior interesse por estudos tratando de visualização para esses conceitos. Precisase destacar que, para esse grupo de conceitos, há um alto grau de abstração relacionado, tornando-se, por isso, um campo ideal para o uso e desenvolvimento de modelos e de ferramentas de visualização.

Destaca-se também que, apesar de ainda pouco utilizados, os recursos computacionais destinados ao aprendizado de técnicas de laboratório podem ser grandes aliados no ensino de química. ${ }^{53}$ Tal afirmação decorre da importância que o laboratório tem para o ensino desta disciplina e, ao mesmo tempo, da dificuldade de se implantar laboratórios nas escolas. ${ }^{54}$

Alguns autores destacam, por exemplo, os custos de manutenção de um laboratório ${ }^{55}$ e o elevado número de alunos nas turmas ${ }^{56}$ como fatores que estimulariam o uso de ferramentas computacionais, permitindo ao aluno simular diferentes técnicas e procedimentos, além de utilizar reagentes diversos, o que nem sempre seria possível de se fazer no ambiente real de um laboratório.

O uso de simulações também é reportado para situações de ensino à distância, com os objetivos de familiarizar os alunos de um curso de química à distância com o laboratório e prepará-los para as aulas práticas presenciais. ${ }^{57}$ Como atividades pré-laboratório, as simulações também podem contribuir para preparar melhor os alunos para o trabalho prático, possibilitando o treinamento de técnicas e fornecendo o embasamento teórico associado ao experimento. ${ }^{58} \mathrm{Com}$ isso, as atividades de laboratório seriam muito mais significativas para os alunos.

\section{Produção por metodologia usada no contexto educacional}

A produção de artigos por metodologia aplicada a cada ano está representada na Figura 4.

Primeiramente, deve-se apontar para a discreta redução no número de publicações sem citações da metodologia de pesquisa aplicada ao longo dos anos. A escolha pelo trabalho em grupo é a mais comum, seguida pelo trabalho individual, metodologias que, em número, não variaram muito no período considerado.

É preciso ressaltar, porém, que o trabalho em grupo não necessariamente implica trabalho colaborativo, em que a discussão entre alunos e/ou com o professor aparece como estratégia de ensino e parte integrante da sequência didática adotada, podendo essa interação ser ou não objeto de investigação mais detalhada. 


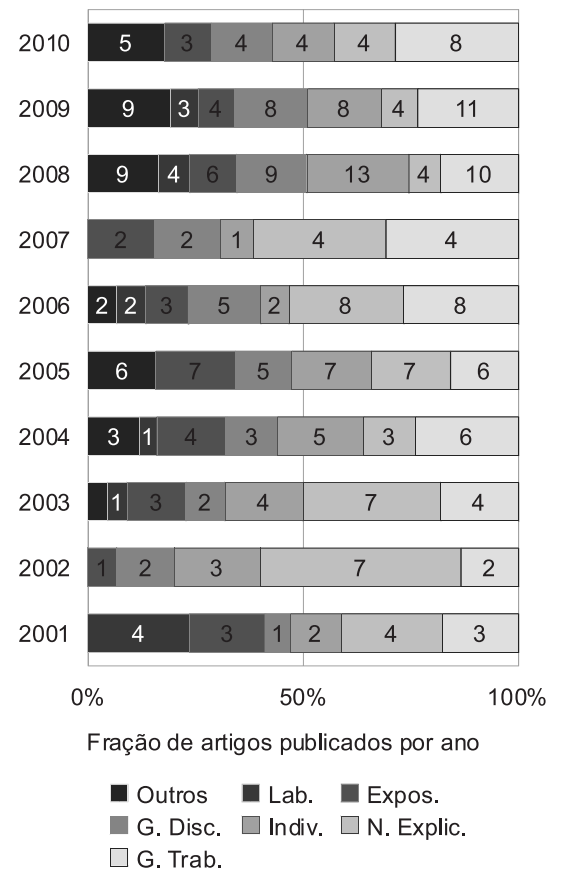

Figura 4. Classificação da produção anual de artigos por metodologia de ensino. Os dados em barras exprimem para cada ano a produção em termos do \% do total de artigos publicados no ano. Os números nas barras indicam os valores absolutos. As metodologias de ensino indicadas nos artigos foram classificadas nas categorias: $i-G$. Trab.: trabalho em grupo; $i i-N$. Explic.: metodologia não explicitada; iii - Indiv.: trabalho individual; iv - G. Disc.: grupos de discussão; $v$ - Expos.: aula expositiva; vi - Lab.: atividades em laboratório; vii-Outros

A realização do trabalho em grupo, em duplas, por exemplo, pode ser mais uma questão de organização da infraestrutura disponível do que metodológica, como em trabalhos realizados em laboratório. ${ }^{59} \mathrm{Ou}$ seja, é possível que a limitação de recursos ou espaço tenha sido o fator decisivo para que o trabalho fosse feito em grupo em alguns casos.

A respeito disso, é interessante citar o estudo de Ardac e Akaygun, ${ }^{60}$ que comparou o uso de animações no ensino de transformações químicas e físicas entre alunos que fizeram uso individual de computadores e alunos que assistiram à animação demonstrada pelo professor em um computador único. De acordo com a pesquisa, a possibilidade de os próprios alunos explorarem a ferramenta de visualização, em vez de somente acompanharem o seu uso pelo professor, levou ao melhor entendimento dos conceitos abordados. Neste caso, portanto, havia condições para que parte dos alunos trabalhasse individualmente, o que pode não ter acontecido em outros trabalhos.

Deste modo, é mais compreensível também o fato de que os grupos de discussão sejam menos adotados do que o trabalho individual, apesar de o trabalho em grupo ser a opção mais comum de metodologia.

Dentre os trabalhos que avaliam a interatividade entre os alunos, cabe destacar a pesquisa de Liu et al. ${ }^{42}$ segundo a qual o conhecimento prévio dos alunos influencia a interação entre os mesmos nas atividades em grupo. No estudo, em que foi proposta a resolução de um problema de eletroquímica utilizando simulação computacional, as duplas de alunos com menor conhecimento prévio sobre o assunto apresentaram interações menos significativas enquanto resolviam o problema do que as duplas com maior conhecimento prévio ou as duplas mistas, em que os integrantes possuíam níveis diferentes de conhecimento prévio.

Nota-se ainda uma prevalência de trabalhos com enfoque cognitivistas (centrados na interação aluno - recursos de visualização) e menos situacionais (alunos - professor - recursos de visualização), o que evidencia uma necessidade de ampliação das pesquisas com enfoque situacional, considerando que as atividades de ensino ocorrem majoritariamente no plano social da sala de aula, muitas vezes por mediações entre os alunos, professores e ferramentas ou recursos.

Mais um dado interessante é o ligeiro aumento na diversificação das metodologias aplicadas, que pode estar relacionado a uma escolha dos pesquisadores de realizar um conjunto de diferentes atividades em suas pesquisas, uma vez que as metodologias aplicadas estão longe de serem mutuamente excludentes.

\section{Produção por metodologia de pesquisa educacional}

A Figura 5 mostra a evolução das publicações ao longo dos anos de acordo com a metodologia de pesquisa empregada.

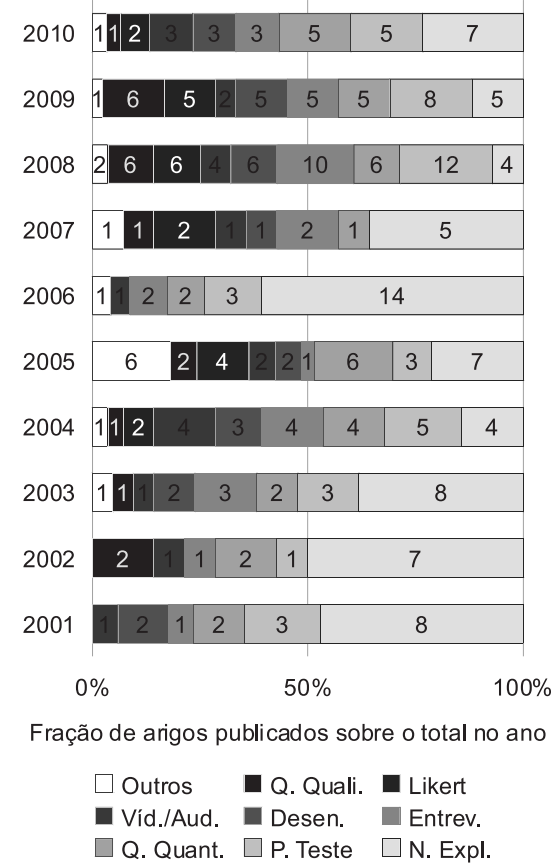

Figura 5. Classificação da produção anual de artigos por metodologia de pesquisa indicada. Os dados em barras exprimem para cada ano a produção em termos do \% do total de artigos com viés investigativo publicados no ano. Os números nas barras indicam os valores absolutos. As metodologias indicadas nos artigos foram classificadas nas categorias: $i-N$. Expl.: metodologia não explicitada; $i i-P$. Teste: análise comparativa de pré e pós-testes; iii-Q. Quant.: questionários com análise quantitativa; iv - Entrev.: entrevista; v-Desen.: análise de desenhos; vi -Vid/Aud.: vídeo e áudio; vii -Likert: avaliação do tipo Likert; viii-Q. Quali.: questionários com análise qualitativa; ix-Outros

Observa-se claramente predomínio dos artigos sem citação explícita da metodologia de pesquisa empregada. Tais trabalhos apontam resultados obtidos com estudantes, mas não deixam claro qual o método de pesquisa empregado para a obtenção de tais dados, valendo-se em muitos casos do relato dos autores como validação dos resultados. Contudo, essa tendência tem diminuído com o tempo, o que indica um processo de amadurecimento dentre aqueles que se propõem a investigar minimamente o papel da visualização no aprendizado.

Entre aqueles que indicam explicitamente uma metodologia de pesquisa, é mais frequente a aplicação de metodologias de pesquisa quantitativas, abrangendo testes e questionários cuja avaliação é de caráter quantitativo e estatístico. Apesar disso, verifica-se uma tendência de redução no uso dessas metodologias, com aumento 
das pesquisas com metodologias mais qualitativas, que utilizam, por exemplo, entrevistas, desenhos e gravações em vídeo ou áudio. Nota-se que, embora ainda predominem as pesquisas que abordam os impactos do uso de recursos de visualização, como softwares, por exemplo, começa a aumentar o número de trabalhos que privilegiam os processos pelos quais os alunos aprendem em situações apoiadas por ferramentas de visualização.

Tais resultados concordam com os de outras pesquisas, que mostram o aumento das metodologias qualitativas comparado às quantitativas. ${ }^{28,61}$ Em alguns casos, as gravações em vídeo ou áudio têm como propósito apenas registrar a sequência didática aplicada, sem uma finalidade clara de avaliar processos interacionais. ${ }^{62}$ Porém, em outros, as mesmas têm como objetivo registrar as interações dos alunos com o professor e/ou entre seus pares e/ou com a ferramenta de visualização utilizada, para uma análise posterior do processo de aprendizagem. ${ }^{63}$ Segundo Schnetzler, ${ }^{22}$ no final dos anos 70, houve uma mudança de foco nas pesquisas educacionais, dando-se mais atenção aos processos de aprendizagem do que de ensino, o que contribuiu para uma alteração também no tipo de metodologia de pesquisa aplicada, de mais quantitativa para mais qualitativa.

Também se deve atentar para a possibilidade de metodologias mistas, em que mais de um instrumento metodológico é utilizado, de forma complementar. Dos trabalhos analisados, por exemplo, muitos fizeram uso de mais do que três metodologias de pesquisa diferentes. ${ }^{64}$ Segundo Prain et al.,${ }^{65}$ que fizeram uso de entrevistas, desenhos e questionários em um estudo abordando a natureza particulada da matéria, o emprego de metodologias de pesquisa diferentes permite aos alunos expressarem melhor o que sabem, uma vez que podem apresentar performances distintas ao expressar o seu conhecimento, dependendo da maneira como se dá essa expressão, seja por representações verbais, gestuais, escritas ou pictóricas.

Além disso, a opção por metodologias de pesquisa variadas permite ao professor investigar e questionar inconsistências e contradições nas formas de representação utilizadas pelos alunos. ${ }^{66}$ Kelly e Jones, ${ }^{67}$ por exemplo, avaliaram o efeito do uso de uma animação no aprendizado do processo de dissolução por alunos de um curso de química. As autoras notaram que a qualidade de seus desenhos melhorou após os alunos assistirem à animação. Entretanto, verificou-se que muitos alunos cujos desenhos foram avaliados como bons pelas pesquisadoras apresentaram erros conceituais nas entrevistas, sugerindo que seus desenhos apenas refletiam o que havia sido observado na animação.

\section{Produção por tipo de meio suporte didático}

Verifica-se na Figura 6 a produção bibliográfica por tipo de meio suporte didático a cada ano. Conforme referem Wu e Shah, ${ }^{1}$ as diferentes ferramentas de visualização são destinadas a dificuldades específicas de aprendizagem, citando as potencialidades de cada tipo de recurso.

De acordo com os resultados, o tipo de suporte mais empregado é aquele de natureza interativa, compreendendo softwares computacionais que oferecem possibilidades de interação modulada com a informação e, em alguns poucos casos, entre usuários. A ampliação do uso desses recursos pode ter sido motivada pelo rápido avanço tecnológico, que contribuiu para o desenvolvimento de softwares educacionais. ${ }^{68} \mathrm{Já}$ a interatividade entre aluno e ferramenta educacional, quando incorporada à prática pedagógica, favorece a elaboração conceitual entre os estudantes, que se tornam mais engajados no processo de aprendizagem. ${ }^{69}$

Diversos trabalhos demonstram os efeitos positivos da utilização de softwares interativos no ensino de química. ${ }^{70}$ Nestes estudos, os alunos do grupo de pesquisa que fizeram uso deste recurso obtiveram melhor desempenho em avaliações realizadas após a aplicação

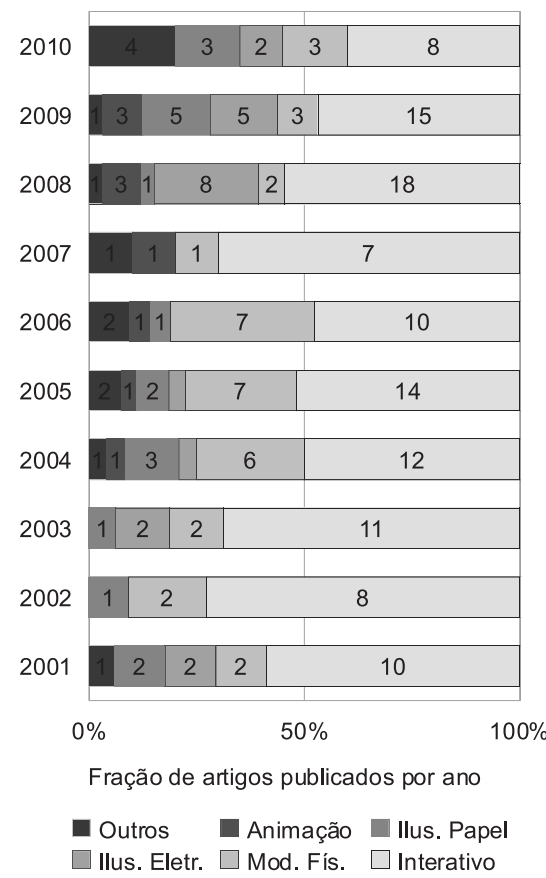

Figura 6. Classificação da produção anual de artigos, segundo meio suporte do curso didático. Os dados em barras exprimem para cada ano a produção em termos do \% do total de artigos publicados no ano. Os números nas barras indicam os valores absolutos. Os meios suporte dos recursos de visualização indicados nos artigos foram classificadas nas categorias: $i$ - Interativo: programa computacional interativo; $i i-M o d$. Físico: modelos moleculares físicos; iii - Ilus. Eletr.: ilustração em meio eletrônico; iv - Ilus. Papel: ilustração impressa; $v$-Animação: animações com possibilidades mínimas de controle; vi-Outros

da sequência didática, quando comparados aos alunos do grupo controle, que tiveram aulas sobre o mesmo assunto, mas sem o uso do software. No entanto, o melhor desempenho nem sempre parece refletir um aprendizado significativo do conceito abordado, pois, em longo prazo, grupos controle e de pesquisa podem apresentar resultados semelhantes na mesma avaliação, ${ }^{49}$ o que sugere a necessidade de mais estudos acerca do assunto.

Sobre o uso dessa tecnologia pelos professores, aqueles que a utilizam afirmam que falta incentivo ao emprego de softwares na sala de aula, ressaltando a necessidade de treinamento pedagógico e técnico aos professores para a utilização efetiva dessa tecnologia na prática docente. ${ }^{71}$

A despeito das variações no número de artigos publicados que citam o software interativo como suporte, não é possível observar uma tendência clara de aumento ou diminuição de seu uso no período considerado. Em contrapartida, o emprego de modelos moleculares físicos parece estar diminuindo ao longo dos anos, apesar de alguns autores defenderem que o uso de modelos físicos pode ser mais eficiente no ensino de química, uma vez que são ferramentas mais concretas, possíveis de serem tocadas e manipuladas, características estas que favoreceriam o aprendizado dos alunos. ${ }^{72}$ Atentos às potencialidades e limitações de cada recurso, alguns estudos apontam que o uso associado de modelos físicos com outras ferramentas de visualização, como os softwares, pode melhorar o aprendizado de química. $^{73}$

\section{CONSIDERAÇÕES FINAIS}

Este trabalho apresentou características gerais da pesquisa em visualização no ensino de química na última década, mostrando 
que este tema tem despertado o interesse de mais pesquisadores da educação, de diferentes países. Contudo, ainda se verifica certa predominância de trabalhos provenientes de países de língua inglesa a despeito da participação crescente de nações falantes de outras línguas. Os trabalhos na área utilizam mais metodologias de investigação quantitativas, apesar de se observar uma tendência de se usar metodologias de caráter mais qualitativo. $\mathrm{O}$ uso deste tipo de metodologia permite, no caso da pesquisa em visualização no ensino de química, o acesso à forma como os alunos constroem os seus modelos mentais, o que está de acordo com a influência atribuída a estas ferramentas na construção destes modelos e na aprendizagem. Os trabalhos em grupo predominam como metodologia aplicada, assim como as pesquisas que tratam de recursos didáticos, muito embora as pesquisas investigativas estejam aumentando. A maior parte dos estudos envolve principalmente o uso de ferramentas computacionais de visualização dedicadas comumente aos conceitos relacionados à estrutura da matéria.

Este estudo evidencia a necessidade de se direcionar as pesquisas sobre o tema visualização, visando a ampliar o entendimento sobre o tema e suas implicações diretas e indiretas ao ensino de química. Destacamos a produção ainda incipiente relacionada ao papel da visualização na formação de professores quer seja inicial ou em serviço, bem como as pesquisas sobre os processos de aprendizagem dos alunos em atividades apoiadas por ferramentas visuais por meio de pesquisas qualitativas.

\section{MATERIAL SUPLEMENTAR}

No material suplementar, encontra-se a tabela de dados a partir dos quais se realizou este estudo. Nessa tabela, estão compiladas as referências de cada artigo - incluindo título do periódico e do artigo, ano, volume e página da publicação, autores e palavras-chave - além da classificação de cada trabalho analisado, segundo os parâmetros de categorização empregados na metodologia de pesquisa. Está disponível em http://quimicanova.sbq.org.br, em arquivo pdf, com acesso livre.

\section{REFERÊNCIAS}

1. Wu, H-K.; Shah, P.; Sci. Educ. 2004, 88, 465.

2. Gobert, J. D. Em Leveraging technology and cognitive theory on visualization to promote students' science learning and literacy; Gilbert, J. K., ed.; Springer: Netherlands, 2005.

3. Gilbert, J. K.; Reiner, M.; Nakhleh, M. Em Introduction; Gilbert, J. K; Reiner, M.; Nakhleh, M., eds.; Springer: New York, 2008.

4. Barnea, N. Em Teaching and learning about chemistry and modeling with a computer-managed modeling system; Gilbert, J. K.; Boulter, C., eds.; Kluwer: Dordrecht, 2000; Greca, I. M. Em Algumas metodologias para o estudo de modelos; Santos, F.; Greca, I. M., eds.; Unijuí: Ijuí, 2007; Gilbert, J. K. Em Visualization: a metacognitive skill in science and science education; Gilbert, J. K., ed.; Springer: Dordrecht, 2007; Rapp, D. N. Em Mental models: theorical issues for visualizations in science education; Gilbert, J. K., ed.; Springer: Dordrecht, 2007; Rapp, D.; Kurby, C. Em The 'ins' and 'outs' of learning: internal representations and external visualizations; Gilbert, J. K; Reiner, M.; Nakhleh, M., eds.; Springer: New York, 2008; Reiner, M. Em The nature and development of visualization: a review of what is known; Gilbert, J. K; Reiner, M.; Nakhleh, M., eds.; Springer: New York, 2008.

5. Wu, H.; Krajcik, J. S.; Soloway, J.; J. Res. Sci. Teach. 2001, 38, 821; Ferk, V.; Vrtacnik, M.; Blejec, A.; Girl, A.; Int. J. Sci. Educ. 2003, 25, 1227; Santos, F. M. T.; Greca, I. M.; REEC 2005, 4; Tasker, R.; Dalton, R.; Chem. Educ. Res. Pract. 2006, 7, 141; Savec, V.; Vrtacnik, M.; Gilbert, J. K. Em Evaluating the Educational Value of Molecular Structure
Representations; Gilbert, J. K., ed.; Springer: Dordrecht, 2007; Kozma, R.; Russell, J. Em Assessing learning from the use of multimedia chemical visualization software; Gilbert, J. K., ed.; Springer: Dordrecht, 2007; Arroio, A.; Honório, K.; PEC 2008, 9, 17.

6. Gilbert, J. K.; Justi, R.; Queiroz, A. S. Em The use of a model of modelling to develop visualization during the learning of ionic bonding; Tasar, M. F.; Cakmakci, G., eds.; Pegem Akademi: Ankara, 2010.

7. Justi, R.; Gilbert, J. K.; Int. J. Sci. Educ. 2002, 24, 369.

8. Chittleborough, G.; Treagust, D.; Res. Sci. Educ. 2008, 38, 463.

9. Cook, M. P.; Sci. Educ. 2006, 90, 1073.

10. Treagust, D.; Chittleborough, G.; Mamiala, T.; Int. J. Sci. Educ. 2003, 25, 1353.

11. Yang, E.; Andre, T.; Greenbowe, T. J.; Tibell, L.; Int. J. Sci. Educ. 2003, $25,329$.

12. Giordan, M.; Góis, J.; Enseñanza de las Ciencias 2005, 23, 1.

13. Costa, M. J.; Galembeck, E.; Marson, G. A.; Torres, B. B.; PloS Comput. Biol. 2008, 4, e1000035.

14. Schonborn, K. J.; Anderson, T. R.; BAMBED 2006, 34, 94.

15. Ferreira, C.; Arroio, A.; PEC 2009, 16, 48.

16. Kozma, R.; Russell, J. Em Pupils becoming chemists: developing representational competence; Gilbert, J. K., ed.; Springer: Dordrecht, 2007.

17. Greeno, J.; American Psychologist 1998, 53, 5.

18. Marson, G. A.; Torres, B. B.; J. Chem. Educ. 2011, 88, 1616.

19. Chang, Y-H.; Chang, C-Y.; Tseng, Y-H.; J. Sci. Educ. Technol. 2010, 19 , 315.

20. Megid Neto, J.; Pacheco, D. Em Pesquisas sobre o ensino de física no nível médio no Brasil: concepção e tratamento de problemas em teses e dissertações; Nardi, R., org.; Escrituras: São Paulo, 2001.

21. Haddad, S., coord.; Evolução de jovens e adultos no Brasil (1996-1998), MEC/INEP/COMPED: Brasília, 2002, (Série: Estado do conhecimento).

22. Schnetzler, R. P.; Quim. Nova 2002, 25 supl. 1, 14.

23. Francisco, C. A.; Queiroz, S. L.; Quim. Nova 2008, 31, 2100.

24. Severino, A. J.; Metodologia do trabalho científico, Cortes: São Paulo, 1976.

25. Ferreira, N. S. A.; Educação e sociedade 2002, 23, 257.

26. Talanquer, V.; Int. J. Sci. Educ. 2011, 33, 179.

27. Gabel, D.; J. Chem. Educ. 1999, 76, 548.

28. Lee, M-S.; Wu, Y-T.; Tsai, C-C.; Int. J. Sci. Educ. 2009, 31, 1999.

29. Vygotsky, L. S.; Mind in Society, Harvard University Press: Cambridge, 1978.

30. Wertsch, J. V.; Vygotsky e a formação social da mente, Ediciones Paidos: Barcelona, 1988.

31. Machado, A. H.; Aula de Química: discurso e conhecimento, Editora Unijuí: Ijuí,1999.

32. Paivio, A.; Mental representations: a dual-coding approach, Oxford Uni Press: New York, 1986

33. Sweller, J.; Cognitive load theory: a special issue of educational psychologist, LEA Inc.: London, 2003.

34. Mayer, R.; Multimedia learning, Cambridge University Press: New York, 2001.

35. Reed, S. K.; Educational Psychologist 2006, 41, 87.

36. Johnson-Laird, P. N.; Mental Models, Harvard University Press: Cambridge, 1983.

37. Sternberg, R. J.; Cognitive psychology, Harcourt Brace College Publishers: Forth Worth, 1996.

38. Cheng, M.; Gilbert, J. K. Em Towards a better utilization of diagrams in research into the use of representative levels in chemical education; Gilbert, J. K.; Treagust, D., eds.; Springer: New York, 2009.

39. Gilbert, J. K. Em Visualization: a metacognitive skill in science and science education; Gilbert, J. K., ed.; Springer: Dordrecht, 2007; Rapp, D. N. Em Mental models: theorical issues for visualizations in science education; Gilbert, J. K., ed.; Springer: Dordrecht, 2007; Briggs, M.; Bodner, G. Em A model of molecular visualization; Gilbert, J. K., ed.; 
Springer: Dordrecht, 2007; Rapp, D.; Kurby, C. Em The 'ins' and 'outs' of learning: internal representations and external visualizations; Gilbert, J. K.; Reiner, M.; Nakhleh, M., eds.; Springer: New York, 2008.

40. Evans, K. L.; Yaron, D.; Leinhardt, G.; Chem. Educ. Res. Pract. 2008, 9, 208; Özmen, H.; Comput. Educ. 2008, 51, 423; Özmen, H.; Demircioglu, H.; Demircioglu, G.; Comput. Educ. 2009, 52, 681; Limniou, M.; Papadopoulos, N.; Whitehead, C.; Comput. Educ. 2009, 52, 45; Yang, E. M.; Greenbowe, T. J.; Andre, T.; J. Chem. Educ. 2004, 81, 587; Arasasingham, R. D.; Taagepera, M.; Potter, F.; Martorell, I.; Lonjers, S.; J. Chem. Educ. 2005, 82, 1251; Yezierski, E. J.; Birk, J. P.; J. Chem. Educ. 2006, 83, 954; Frailich, M.; Kesner, M.; Hofstein, A.; J. Res. Sci. Teach. 2009, 46, 289; Rotbain, Y.; Marbach-Ad, G.; Stavy, R.; J. Sci. Educ. Technol. 2008, 17, 49.

41. Trey, L.; Khan, S.; Comput. Educ. 2008, 51, 519; Limniou, M.; Roberts, D.; Papadopoulos, N.; Comput. Educ. 2008, 51, 584; Yang, E.; Andre, T.; Greenbowe, T. J.; Tibell, L.; Int. J. Sci. Educ. 2003, 25, 329; Ardac, D.; Akaygun, S.; Int. J. Sci. Educ. 2005, 27, 1269; Aldahmash, A. H.; Araham, M. R.; J. Chem. Educ. 2009, 86, 1442; Rotbain, Y.; MarbachAd, G.; Stavy, R.; J. Res. Sci. Teach. 2006, 43, 500; Marbach-Ad, G.; Rotbain, Y.; Stavy, R.; J. Res. Sci. Teach. 2008, 45, 273.

42. Liu, H. C.; Andre, T.; Greenbowe, T. J.; J. Sci. Educ. Technol. 2008, 17, 466.

43. Cook, M.; Wiebe, E. N.; Carter, G.; Sci. Edu. 2008, 92, 848.

44. Cook, M. P.; Sci. Edu. 2006, 90, 1073.

45. Giudice, J.; Galagovsky, L.; REEC 2008, 7, 629.

46. Adadan, E.; Irving, K. E.; Trundlek, K. C.; Int. J. Sci. Educ. 2009, 31, 1743.

47. Yezierski, E. J.; Birk, J. P.; J. Chem. Educ. 2006, 83, 954.

48. Yezierski, E. J.; Birk, J. P.; J. Chem. Educ. 2006, 83, 954; Snir, J.; Smith, C. L.; Raz G.; Sci. Edu. 2003, 87, 794.

49. Stern, L.; Barnea, N.; Shauli, S.; J. Sci. Educ. Technol. 2008, 17, 305.

50. Pellegrinet, S. C.; Mata, E. G.; J. Chem. Educ. 2005, 82, 73.

51. Sandvoss, L. M.; Harwood, W. S.; Korkmaz, A.; Bollinger, J. C.; Huffman, J. C.; Huffman, J. N.; J. Sci. Educ. Technol. 2003, 12, 277.

52. Mc Kay, S. E.; Boone, S. R.; J. Chem. Educ. 2001, 78, 1487; Sein Jr, L. T.; J. Chem. Educ. 2010, 87, 827; Korkmaz, A.; Harwood, W. S.; J. Sci. Educ. Technol. 2004, 13, 243; Nottis, K. E. K.; Kastner, M. E.; J. Sci. Educ. Technol. 2005, 14, 51

53. Dalagarno, B.; Bishop, A. G.; Adlong, W.; Bedgood Jr, D. R.; Comput. Educ. 2009, 53, 853; Limniou, M.; Papadopoulos, N.; Whitehead, C.; Comput. Educ. 2009, 52, 45; Papadopoulos, N.; Limniou, M.; J. Chem. Educ. 2003, 80, 709; Martínez-Jiménez, P.; Pontes-Pedrajas, A.; Polo, J.; Climent-Bellido, M. S.; J. Chem. Educ. 2003, 80, 346.

54. Pinto, A. C.; J. Braz. Chem. Soc. 2008, 19, nº 5, editorial.

55. Papadopoulos, N.; Limniou, M.; J. Chem. Educ. 2003, 80, 709.

56. Martínez-Jiménez, P.; Pontes-Pedrajas, A.; Polo, J.; Climent-Bellido, M. S.; J. Chem. Educ. 2003, 80, 346.
57. Dalagarno, B.; Bishop, A. G.; Adlong, W.; Bedgood Jr, D. R.; Comput. Educ. 2009, 53, 853.

58. Limniou, M.; Papadopoulos, N.; Whitehead, C.; Comput. Educ. 2009, 52,45 .

59. Ghaffari, S.; J. Chem. Educ. 2006, 83, 1182; Bindel, T. H.; J. Chem. Educ. 2008, 85, 303.

60. Ardac, D.; Akaygun, S.; Int. J. Sci. Educ. 2005, 27, 1269.

61. White, R.; Res. Sci. Educ. 2007, 27, 215.

62. Nottis, K. E. K.; Kastner, M. E.; J. Sci. Educ. Technol. 2005, 14, 51; Santos, F. M. T.; Greca, I. M.; REEC 2005, 4.

63. Pierri, E.; Karatrantou, A.; Panagiotakopoulos, C.; Chem. Educ. Res. Pract. 2008, 9, 234; Treagust, D. F.; Chittleborough, G.; Mamiala, T. L.; Int. J. Sci. Educ. 2003, 25, 1353; Maia, P. F.; Justi, R.; Int. J. Sci. Educ. 2009, 31, 603; Wu, H. K.; Krajcik, J. S.; Soloway, E.; J. Res. Sci. Teach. 2001, 38, 821; Treagust, D. F.; Chittleborough, G. D.; Mamiala, T. L.; Res. Sci. Educ. 2004, 34, 1.

64. Tuvi-Arad, I.; Blonder, R.; Chem. Educ. Res. Pract. 2010, 11, 48; Kelly, R. M.; Jones, L. L.; J. Chem. Educ. 2008, 85, 303; Kerby, H. W.; Cantor, J.; Weiland, M.; Barbiarz, C.; Kerby, A. W.; J. Chem. Educ. 2010, 87, 1024; Wu, H. K.; Krajcik, J. S.; Soloway, E.; J. Res. Sci. Teach. 2001, 38, 821; Kelly, R. M.; Jones, L. L.; J. Sci. Educ. Technol. 2007, 16, 413; Liu, H. C.; Andre, T.; Greenbowe, T. J.; J. Sci. Educ. Technol. 2008, 17, 466; Treagust, D. F.; Chittleborough, G. D.; Mamiala, T. L.; Res. Sci. Educ. 2004, 34, 1.

65. Prain, V.; Tytler, R.; Peterson, S.; Int. J. Sci. Educ. 2009, 31, 787.

66. Ardac, C.; Akaygun, S.; J. Res. Sci. Teach. 2004, 41, 317.

67. Kelly, R. M.; Jones, L. L.; J. Sci. Educ. Technol. 2007, 16, 413.

68. Arroio, A.; Honório, K. M.; Weber, K. C.; Homem-de-Mello, P.; da Silva, A. B. F.; Quim. Nova 2005, 28, 360.

69. Ferreira, C.; Arroio, A.; Rezende, D. B.; Quim. Nova 2011, 34, 1661.

70. Özmen, H.; Comput. Educ. 2008, 51, 423; Özmen, H.; Demircioglu, H.; Demircioglu, G.; Comput. Educ. 2009, 52, 681; Yang, E. M.; Greenbowe, T. J.; Andre, T.; J. Chem. Educ. 2004, 81, 587; Arasasingham, R. D.; Taagepera, M.; Potter, F.; Martorell, I.; Lonjers, S.; J. Chem. Educ. 2005, 82, 1251; Frailich, M.; Kesner, M.; Hofstein, A.; J. Res. Sci. Teach. 2009, 46, 289; Rotbain, Y.; Marbach-Ad, G.; Stavy, R.; J. Sci. Educ. Technol. 2008, 17, 49; Stern, L.; Barnea, N.; Shauli, S.; J. Sci. Educ. Technol. 2008, 17, 305.

71. Aksela, M.; Lundell, J.; Chem. Educ. Res. Pract. 2008, 9, 301.

72. Herman, T.; Colton, S.; Batiza, A.; Patrick, M.; Franzen, M.; Goodsell, D. S.; BAMBED 2006, 34, 247; Pellegrinet, S. C.; Mata, E. G.; J. Chem. Educ. 2005, 82, 73.

73. Roberts, J. R.; Hagedorn, E.; Dillenburg, P.; Patrick, M.; Herman, T.; BAMBED 2005, 33, 105; Cox, J. P. L.; J. Chem. Educ. 2006, 83, 1319; Geldenhuys, W. J.; Hayes, M.; Vand Der, Schyf, C. J.; Allen, D. D.; Malan, S. F.; J. Chem. Educ. 2007, 84, 979. 


\section{VISUALIZAÇÃO NO ENSINO DE QUÍMICA: APONTAMENTOS PARA A PESQUISA E DESENVOLVIMENTO DE RECURSOS EDUCACIONAIS}

\section{Leila Cardoso Teruya e Guilherme Andrade Marson*}

Departamento de Química Fundamental, Instituto de Química, Universidade de São Paulo, Av. Prof. Lineu Prestes, 748, 05508-000 São Paulo - SP, Brasil

\section{Celeste Rodrigues Ferreira e Agnaldo Arroio}

Departamento de Metodologia do Ensino e Educação Comparada, Faculdade de Educação, Universidade de São Paulo, Av. da Universidade, 308, 05508-040 São Paulo - SP, Brasil

Tabela 1S. Dados a partir dos quais se realizou o estudo

\begin{tabular}{|c|c|c|c|c|c|c|c|c|c|}
\hline Ref. & Título & Autores & $\begin{array}{l}\text { País da } \\
\text { instituição } \\
\text { do } 1^{\circ} \text { autor }\end{array}$ & Tipo de artigo & Palavras-chave & $\begin{array}{l}\text { Conceitos } \\
\text { (até 2) }\end{array}$ & $\begin{array}{l}\text { Metodologia de } \\
\text { pesquisa (até 4) }\end{array}$ & $\begin{array}{c}\text { Metodologia } \\
\text { usada no contexto } \\
\text { educacional } \\
\text { (até 5) }\end{array}$ & $\begin{array}{c}\text { Meio } \\
\text { suporte } \\
\text { didático } 1 \\
\text { (até 3) }\end{array}$ \\
\hline $\begin{array}{l}\text { BAMBED 2001, } \\
29,3\end{array}$ & $\begin{array}{l}\text { Computer-Assisted } \\
\text { Simulations Of Phos- } \\
\text { phofructokinase-1 Ki- } \\
\text { netics Using Simplified } \\
\text { Velocity Equations }\end{array}$ & $\begin{array}{l}\text { Roy H; Diwan } \\
\text { J; Segel L D; } \\
\text { Segel I H }\end{array}$ & EUA & $\begin{array}{l}\text { Recurso } \\
\text { didático }\end{array}$ & $\begin{array}{l}\text { phosphofructoki- } \\
\text { nase; simulations; } \\
\text { allosteric; computer; } \\
\text { cooperativity; ki- } \\
\text { netics }\end{array}$ & cinética & Não citada & $\begin{array}{l}\text { Trabalho indi- } \\
\text { vidual, Trabalho } \\
\text { em grupo }\end{array}$ & Interativo \\
\hline $\begin{array}{l}\text { BAMBED 2002, } \\
30,93\end{array}$ & $\begin{array}{l}\text { Student Difficulties } \\
\text { With The Interpretation } \\
\text { Of A Textbook Diagram } \\
\text { Of Immunoglobulin } \\
\text { G (Igg) }\end{array}$ & $\begin{array}{l}\text { Schönborn K } \\
\text { J; Anderson } \\
\text { T R; Grayson } \\
\text { D J }\end{array}$ & $\begin{array}{l}\text { África do } \\
\text { Sul }\end{array}$ & $\begin{array}{l}\text { Recurso } \\
\text { didático }\end{array}$ & $\begin{array}{l}\text { student's conceptual } \\
\text { and reasoning dif- } \\
\text { ficulties; textbook } \\
\text { diagrams; teaching } \\
\text { and learning }\end{array}$ & proteínas & $\begin{array}{l}\text { Question- } \\
\text { ários: qualitativo, } \\
\text { Vídeo/Áudio, } \\
\text { Entrevistas }\end{array}$ & $\begin{array}{l}\text { Trabalho indi- } \\
\text { vidual }\end{array}$ & $\begin{array}{l}\text { Ilustração } \\
\text { em papel }\end{array}$ \\
\hline $\begin{array}{l}\text { BAMBED 2002, } \\
30,209\end{array}$ & $\begin{array}{l}\text { Using Three-Dimen- } \\
\text { sional Imaging Of } \\
\text { Proteins: Examples Of } \\
\text { Class Activities And } \\
\text { Subsequent Assess- } \\
\text { ments }\end{array}$ & Willian K R & Reino Unido & $\begin{array}{l}\text { Recurso } \\
\text { didático }\end{array}$ & $\begin{array}{l}\text { receptors; protein } \\
\text { structure; three- } \\
\text { dimensionam } \\
\text { imaging }\end{array}$ & proteínas & $\begin{array}{l}\text { Questionários: } \\
\text { quantitativo }\end{array}$ & $\begin{array}{l}\text { Trabalho indi- } \\
\text { vidual }\end{array}$ & Interativo \\
\hline $\begin{array}{l}\text { BAMBED 2002, } \\
30,21\end{array}$ & $\begin{array}{l}\text { Teaching Molecular } \\
\text { 3-D Literacy }\end{array}$ & $\begin{array}{l}\text { Richardson D } \\
\text { C; Richardson } \\
\text { J S }\end{array}$ & EUA & Metodologia & Não citadas & biomoléculas & $\begin{array}{c}\text { Pré/Pós-testes, } \\
\text { Questionários: } \\
\text { qualitativo }\end{array}$ & $\begin{array}{l}\text { Trabalho indi- } \\
\text { vidual, Trabalho } \\
\text { em grupo, Grupo } \\
\text { de discussão }\end{array}$ & Interativo \\
\hline $\begin{array}{l}\text { BAMBED 2002, } \\
30,130\end{array}$ & $\begin{array}{l}\text { Evaluation Of Mo- } \\
\text { lecular Visualization } \\
\text { Software For Teaching } \\
\text { Protein Structure: Dif- } \\
\text { fering Outcomes From } \\
\text { Lecture And Lab }\end{array}$ & $\begin{array}{l}\text { White B; Kim } \\
\text { S; Sherman K; } \\
\text { Weber N }\end{array}$ & EUA & Metodologia & $\begin{array}{l}\text { evaluation; mo- } \\
\text { lecular visualization; } \\
\text { protein structure }\end{array}$ & proteínas & $\begin{array}{l}\text { Questionários: } \\
\text { quantitativo }\end{array}$ & $\begin{array}{l}\text { Trabalho em } \\
\text { grupo, Grupo de } \\
\text { discussão, Aula } \\
\text { expositiva }\end{array}$ & Interativo \\
\hline $\begin{array}{l}\text { BAMBED 2003, } \\
31,93\end{array}$ & $\begin{array}{l}\text { On The Convenience } \\
\text { Of Using A Computer } \\
\text { Simulation To Teach } \\
\text { Enzyme Kinetics To } \\
\text { Undergraduate Students } \\
\text { With Biological } \\
\text { Chemistry-Related } \\
\text { Curricula }\end{array}$ & $\begin{array}{l}\text { González- } \\
\text { Cruz J; } \\
\text { Rodríguez- } \\
\text { Sotres R; } \\
\text { Rodríguez- } \\
\text { Penagos M }\end{array}$ & México & Investigação & $\begin{array}{l}\text { teaching enzyme- } \\
\text { kinetics; computer- } \\
\text { assisted teaching }\end{array}$ & cinética & $\begin{array}{l}\text { Relatório, Prél } \\
\text { Pós-testes }\end{array}$ & $\begin{array}{l}\text { Trabalho indi- } \\
\text { vidual, Grupo de } \\
\text { discussão, Outros }\end{array}$ & Interativo \\
\hline $\begin{array}{l}\text { BAMBED 2003, } \\
31,234\end{array}$ & $\begin{array}{l}\text { Energy Diagrams For } \\
\text { Enzyme-Catalyzed } \\
\text { Reactions: Concepts } \\
\text { And Misconcepts }\end{array}$ & $\begin{array}{l}\text { Aledo J C; } \\
\text { Lobo C; Del } \\
\text { Valle A E }\end{array}$ & Espanha & $\begin{array}{l}\text { Recurso } \\
\text { didático }\end{array}$ & $\begin{array}{l}\text { reaction coordinate; } \\
\text { activation energy; } \\
\text { thermokinetics }\end{array}$ & cinética & Não citada & Não citada & $\begin{array}{r}\text { Ilustração } \\
\text { em papel }\end{array}$ \\
\hline $\begin{array}{l}\text { BAMBED 2004, } \\
32,201\end{array}$ & $\begin{array}{l}\text { Lucenz Simulator: A } \\
\text { Tool For The Teaching } \\
\text { Of Enzyme Kinetics }\end{array}$ & Clark A G & $\begin{array}{c}\text { Nova } \\
\text { Zelândia }\end{array}$ & $\begin{array}{l}\text { Recurso } \\
\text { didático }\end{array}$ & $\begin{array}{l}\text { kinetics; simulation; } \\
\text { demonstration; } \\
\text { modeling; inhibition; } \\
\text { activation energy } \\
\end{array}$ & cinética & Não citada & Não citada & Interativo \\
\hline $\begin{array}{l}\text { BAMBED 2005, } \\
33,65\end{array}$ & $\begin{array}{l}\text { Software For Teaching } \\
\text { Structure-Hydrophobic- } \\
\text { ity Relationships }\end{array}$ & $\begin{array}{l}\text { White B; } \\
\text { Perna I; } \\
\text { Carison R }\end{array}$ & EUA & Metodologia & $\begin{array}{l}\text { laboratory exercises; } \\
\text { cheminformatics; } \\
\text { hydrophobicity; mo- } \\
\text { lecular properties }\end{array}$ & $\begin{array}{l}\text { interações } \\
\text { intermolecu- } \\
\text { lares, ligação } \\
\text { química }\end{array}$ & $\begin{array}{l}\text { Questionários: } \\
\text { quantitativo }\end{array}$ & $\begin{array}{l}\text { Trabalho em } \\
\text { grupo, Aula } \\
\text { expositiva }\end{array}$ & Interativo \\
\hline
\end{tabular}


Tabela 1S. Dados a partir dos quais se realizou o estudo (continuação)

\begin{tabular}{|c|c|c|c|c|c|c|c|c|c|}
\hline Ref. & Título & Autores & $\begin{array}{c}\text { País da } \\
\text { instituição } \\
\text { do } 1^{\circ} \text { autor }\end{array}$ & Tipo de artigo & Palavras-chave & $\begin{array}{l}\text { Conceitos } \\
\text { (até 2) }\end{array}$ & $\begin{array}{l}\text { Metodologia de } \\
\text { pesquisa (até 4) }\end{array}$ & $\begin{array}{c}\text { Metodologia } \\
\text { usada no contexto } \\
\text { educacional } \\
\text { (até 5) }\end{array}$ & $\begin{array}{c}\text { Meio } \\
\text { suporte } \\
\text { didático } 1 \\
\text { (até 3) }\end{array}$ \\
\hline $\begin{array}{l}\text { BAMBED 2005, } \\
33,105\end{array}$ & $\begin{array}{l}\text { Physical Models En- } \\
\text { hance Molecular Three- } \\
\text { Dimensional Literacy } \\
\text { In An Physical Models } \\
\text { Enhance Molecular } \\
\text { Three-Dimensional } \\
\text { Literacy In An Intro- } \\
\text { ductory Biochemistry } \\
\text { Course }\end{array}$ & $\begin{array}{l}\text { Roberts J R; } \\
\text { Hagedorn E; } \\
\text { Dillenburg } \\
\text { P; Patrick M; } \\
\text { Herman T }\end{array}$ & EUA & Investigação & $\begin{array}{l}\text { physical models; } \\
\text { swiss protein bank } \\
\text { viwer; biochemical } \\
\text { education }\end{array}$ & biomoléculas & $\begin{array}{l}\text { Likert, Question- } \\
\text { ários: quantitativo }\end{array}$ & $\begin{array}{l}\text { Trabalho indi- } \\
\text { vidual, Grupo de } \\
\text { discussão, Aula } \\
\text { expositiva }\end{array}$ & $\begin{array}{l}\text { Modelos } \\
\text { físicos, In- } \\
\text { terativo, }\end{array}$ \\
\hline $\begin{array}{l}\text { BAMBED 2005, } \\
33,194\end{array}$ & $\begin{array}{l}\text { Molecular Modeling Of } \\
\text { Heme Proteins Using } \\
\text { Moe: Bio-Inorganic } \\
\text { And Structure-Function } \\
\text { Activity For Under- } \\
\text { graduates }\end{array}$ & Ray G B & EUA & Metodologia & $\begin{array}{l}\text { mettaloproteins; } \\
\text { computational } \\
\text { biochemistry; three } \\
\text { dimensional-visual- } \\
\text { ization; bioinor- } \\
\text { ganic; MOE } \\
\end{array}$ & proteínas & $\begin{array}{l}\text { Relatórios, } \\
\text { Questionários: } \\
\text { qualitativo }\end{array}$ & $\begin{array}{l}\text { Trabalho em } \\
\text { grupo, Grupo } \\
\text { de discussão, } \\
\text { Outros, Outros }\end{array}$ & Interativo \\
\hline $\begin{array}{l}\text { BAMBED } \mathbf{2 0 0 5} \\
33,319\end{array}$ & $\begin{array}{l}\text { Exploring Protein } \\
\text { Function And Evolution } \\
\text { Using Free Online } \\
\text { Bioinformatics Tools }\end{array}$ & $\begin{array}{l}\text { Weaver T; } \\
\text { Cooper S }\end{array}$ & EUA & Metodologia & $\begin{array}{l}\text { molecular model; } \\
\text { secondary structure; } \\
\text { motif; alignment; } \\
\text { ortholog; paralog }\end{array}$ & proteínas & Questionários & Não citada & Interativo \\
\hline $\begin{array}{l}\text { BAMBED 2006, } \\
34,343\end{array}$ & $\begin{array}{l}\text { Jamvle, A New } \\
\text { Integrated Molecular } \\
\text { Visualization Learning } \\
\text { Environment }\end{array}$ & $\begin{array}{l}\text { Bottomley S; } \\
\text { Chandler D; } \\
\text { Morgan E; } \\
\text { Helmerhorst } \\
\quad \text { E. }\end{array}$ & Austrália & $\begin{array}{l}\text { Recurso } \\
\text { didático }\end{array}$ & $\begin{array}{l}\text { evaluation of com- } \\
\text { puter-based learning } \\
\text { systems; molecular } \\
\text { visualization; in- } \\
\text { teractive learning } \\
\text { environment }\end{array}$ & proteínas & Não citada & $\begin{array}{l}\text { Trabalho em } \\
\text { grupo, Grupo de } \\
\text { discussão }\end{array}$ & Interativo \\
\hline $\begin{array}{l}\text { BAMBED 2006, } \\
34,187\end{array}$ & $\begin{array}{l}\text { A New Three-Dimen- } \\
\text { sional Educational } \\
\text { Model Kit For Building } \\
\text { Dna And Rna Mol- } \\
\text { ecules: Development } \\
\text { And Evaluation }\end{array}$ & $\begin{array}{c}\text { Beltramine L } \\
\text { M; Araújo A P } \\
\text { U; Oliveira T } \\
\text { H G; Abel L D } \\
\text { S; Silva A R; } \\
\text { Santos N F }\end{array}$ & Brasil & $\begin{array}{l}\text { Recurso } \\
\text { didático }\end{array}$ & $\begin{array}{l}\text { nucleic acids; DNA; } \\
\text { RNA; molecular } \\
\text { structures; educa- } \\
\text { tional model and } \\
\text { evaluation }\end{array}$ & $\begin{array}{l}\text { ácidos nuclei- } \\
\qquad \cos \end{array}$ & $\begin{array}{l}\text { Questionários: } \\
\text { quantitativo }\end{array}$ & $\begin{array}{l}\text { Trabalho em } \\
\text { grupo, Grupo de } \\
\text { discussão }\end{array}$ & $\begin{array}{l}\text { Modelos } \\
\text { físicos }\end{array}$ \\
\hline $\begin{array}{l}\text { BAMBED 2006, } \\
34,94\end{array}$ & $\begin{array}{l}\text { The Importance Of } \\
\text { Visual Literacy In } \\
\text { The Education Of } \\
\text { Biochemists }\end{array}$ & $\begin{array}{c}\text { Schönborn K } \\
\text { J; Anderson } \\
\text { T R }\end{array}$ & $\begin{array}{l}\text { África do } \\
\text { Sul }\end{array}$ & Revisão & $\begin{array}{c}\text { external representa- } \\
\text { tion; visual literacy; } \\
\text { visualization; inter- } \\
\text { pretation; teaching; } \\
\text { learning } \\
\end{array}$ & $\begin{array}{l}\text { Não espe- } \\
\text { cificado }\end{array}$ & Não citada & Não citada & Outros \\
\hline $\begin{array}{l}\text { BAMBED 2006, } \\
34,255\end{array}$ & $\begin{array}{l}\text { Biomolecules In The } \\
\text { Computer: Jmol To The } \\
\text { Rescue }\end{array}$ & Herráez A & Espanha & $\begin{array}{l}\text { Recurso } \\
\text { didático }\end{array}$ & $\begin{array}{l}\text { molecular models; } \\
\text { Jmol; Chime; open } \\
\text { source; proteins }\end{array}$ & biomoléculas & Não citada & Não citada & Interativo \\
\hline $\begin{array}{l}\text { BAMBED 2006, } \\
34,247\end{array}$ & $\begin{array}{l}\text { Tactile Teaching: } \\
\text { Exploring Protein } \\
\text { Structure/Function Us- } \\
\text { ing Physical Models }\end{array}$ & $\begin{array}{c}\text { Herman T; } \\
\text { Colton S; } \\
\text { Batiza A; } \\
\text { Patrick M; } \\
\text { Franzen M; } \\
\text { Goodsell D S }\end{array}$ & EUA & Metodologia & Não citadas & proteínas & Não citada & $\begin{array}{c}\text { Trabalho em } \\
\text { grupo, Grupo de } \\
\text { discussão, Outros }\end{array}$ & $\begin{array}{l}\text { Modelos } \\
\text { físicos }\end{array}$ \\
\hline $\begin{array}{l}\text { BAMBED 2006, } \\
34,402\end{array}$ & $\begin{array}{l}\text { Ez-Viz, A Tool For } \\
\text { Simplifying Molecular } \\
\text { Viewing In Pymol }\end{array}$ & $\begin{array}{l}\text { Grell L; } \\
\text { Parkin C; } \\
\text { Slatest L; } \\
\text { Craig P A }\end{array}$ & EUA & $\begin{array}{l}\text { Recurso } \\
\text { didático }\end{array}$ & Não citadas & biomoléculas & Não citada & Não citada & Interativo \\
\hline $\begin{array}{l}\text { BAMBED 2007, } \\
35,238\end{array}$ & $\begin{array}{l}\text { Molecular Modeling } \\
\text { Of Estrogen Receptor } \\
\text { Using Molecular Oper- } \\
\text { ating Environment }\end{array}$ & $\begin{array}{c}\text { Roy U; Luck } \\
\text { LA }\end{array}$ & EUA & $\begin{array}{l}\text { Recurso } \\
\text { didático }\end{array}$ & $\begin{array}{l}\text { computational biol- } \\
\text { ogy; biotechnology } \\
\text { education; comput- } \\
\text { ers in research and } \\
\text { teaching; molecular } \\
\text { modeling; estrogen } \\
\text { receptor; estradiol; } \\
\text { molecular operating } \\
\text { environment }\end{array}$ & $\begin{array}{l}\text { interações in- } \\
\text { termoleculares }\end{array}$ & Não citada & Não citada & Interativo \\
\hline $\begin{array}{l}\text { BAMBED 2008, } \\
36,77\end{array}$ & $\begin{array}{l}\text { Interactive Computer } \\
\text { Simulations Of Genet- } \\
\text { ics, Biochemistry, And } \\
\text { Molecularbiology }\end{array}$ & $\begin{array}{l}\text { White B T; } \\
\text { Bolker E D }\end{array}$ & EUA & Metodologia & $\begin{array}{c}\text { computer } \\
\text { simulation; genetics; } \\
\text { protein folding; bio- } \\
\text { chemistry; molecular } \\
\text { biology }\end{array}$ & $\begin{array}{l}\text { ácidos nuclei- } \\
\text { cos, proteínas }\end{array}$ & $\begin{array}{c}\text { Relatórios, Vídeo/ } \\
\text { Áudio }\end{array}$ & $\begin{array}{l}\text { Trabalho em } \\
\text { grupo, Grupo de } \\
\text { discussão }\end{array}$ & Interativo \\
\hline $\begin{array}{l}\text { BAMBED 2008, } \\
36,203\end{array}$ & $\begin{array}{l}\text { Tonal Interface To Mac- } \\
\text { romolecules (Timmol: } \\
\text { A Textual And Tonal } \\
\text { Tool For Molecular } \\
\text { Visualization }\end{array}$ & $\begin{array}{c}\text { Cordes T J; } \\
\text { Carlson C B; } \\
\text { Forest K T }\end{array}$ & EUA & $\begin{array}{l}\text { Recurso } \\
\text { didático }\end{array}$ & $\begin{array}{c}\text { three-dimensional } \\
\text { visualization; spatial } \\
\text { learning; 3D learn- } \\
\text { ing; macromolecular } \\
\text { structure }\end{array}$ & proteínas & $\begin{array}{l}\text { Pré/Pós-testes, } \\
\text { Likert }\end{array}$ & $\begin{array}{l}\text { Trabalho indi- } \\
\text { vidual }\end{array}$ & Interativo \\
\hline
\end{tabular}


Tabela 1S. Dados a partir dos quais se realizou o estudo (continuação)

\begin{tabular}{|c|c|c|c|c|c|c|c|c|c|}
\hline Ref. & Título & Autores & $\begin{array}{l}\text { País da } \\
\text { instituição } \\
\text { do } 1^{\circ} \text { autor }\end{array}$ & Tipo de artigo & Palavras-chave & $\begin{array}{l}\text { Conceitos } \\
\text { (até 2) }\end{array}$ & $\begin{array}{l}\text { Metodologia de } \\
\text { pesquisa (até 4) }\end{array}$ & $\begin{array}{c}\text { Metodologia } \\
\text { usada no contexto } \\
\text { educacional } \\
\text { (até 5) }\end{array}$ & $\begin{array}{c}\text { Meio } \\
\text { suporte } \\
\text { didático } 1 \\
\text { (até 3) }\end{array}$ \\
\hline $\begin{array}{l}\text { Chem. Educ. Res. } \\
\text { Pract. 2008, 9, } 301\end{array}$ & $\begin{array}{l}\text { Computer-Based } \\
\text { Molecular Modelling: } \\
\text { Finnish School Teach- } \\
\text { ers' Experiences And } \\
\text { Views }\end{array}$ & $\begin{array}{l}\text { Aksela M; } \\
\text { Lundell J }\end{array}$ & Finlândia & Investigação & $\begin{array}{l}\text { information and } \\
\text { communica- } \\
\text { tions technology; } \\
\text { chemistry teaching; } \\
\text { molecular model- } \\
\text { ling; Finish school } \\
\text { chemistry teachers; } \\
\text { upper secondary } \\
\text { school; teacher } \\
\text { training; life-long } \\
\text { learning }\end{array}$ & $\begin{array}{l}\text { Não espe- } \\
\text { cificado }\end{array}$ & $\begin{array}{l}\text { Likert, Question- } \\
\text { ários: qualitativo, } \\
\text { Pré/Pós-testes }\end{array}$ & Outros & Interativo \\
\hline $\begin{array}{l}\text { Chem. Educ. Res. } \\
\text { Pract. 2008, 9, } 234\end{array}$ & $\begin{array}{l}\text { Exploring The Phe- } \\
\text { nomenon Of 'Change } \\
\text { Of Phase' Of Pure } \\
\text { Substances: Using } \\
\text { The Microcomputer- } \\
\text { Based-Laboratory (Mbl } \\
\text { System }\end{array}$ & $\begin{array}{c}\text { Pierri E; } \\
\text { Karatrantou A; } \\
\text { Panagiotako- } \\
\text { poulos C }\end{array}$ & Grécia & Metodologia & $\begin{array}{l}\text { phase change; melt- } \\
\text { ing point; freezing } \\
\text { point; microcomput- } \\
\text { er-based-laboratory } \\
\text { (MBL system }\end{array}$ & $\begin{array}{l}\text { interações in- } \\
\text { termoleculares }\end{array}$ & $\begin{array}{l}\text { Entrevistas, } \\
\text { Vídeo/Áudio }\end{array}$ & $\begin{array}{l}\text { Trabalho em } \\
\text { grupo, Grupo } \\
\text { de discussão, } \\
\text { Trabalho em } \\
\text { laboratório }\end{array}$ & $\begin{array}{l}\text { Ilustração } \\
\text { eletrônica }\end{array}$ \\
\hline $\begin{array}{l}\text { Chem. Educ. Res. } \\
\text { Pract. 2008, 9, } 277\end{array}$ & $\begin{array}{l}\text { Simchemistry As An } \\
\text { Active Learning Tool In } \\
\text { Chemical Education }\end{array}$ & $\begin{array}{l}\text { Bolton K; } \\
\text { Saalman E; } \\
\text { Christie M; } \\
\text { Ingerman A; } \\
\text { Linder C }\end{array}$ & Suécia & Metodologia & $\begin{array}{l}\text { molecular simula- } \\
\text { tion; active learning; } \\
\text { visualization in } \\
\text { learning; cooperative } \\
\text { learning; reflective } \\
\text { diaries }\end{array}$ & $\begin{array}{l}\text { estrutura } \\
\text { molecular, inte- } \\
\text { rações intermo- } \\
\text { leculares }\end{array}$ & $\begin{array}{l}\text { Entrevistas, } \\
\text { Seminários }\end{array}$ & $\begin{array}{l}\text { Trabalho em } \\
\text { grupo, Grupo de } \\
\text { discussão, Aula } \\
\text { expositiva }\end{array}$ & Interativo \\
\hline $\begin{array}{l}\text { Chem. Educ. Res. } \\
\text { Pract. 2008, 9, } 169\end{array}$ & $\begin{array}{l}\text { Impact Of A Pre- } \\
\text { Laboratory Organic- } \\
\text { Extraction Simulation } \\
\text { Comprehension And } \\
\text { Attitudes Of Under- } \\
\text { graduate Chemistry } \\
\text { Students }\end{array}$ & $\begin{array}{l}\text { Supasorn S; } \\
\text { Suits J P; } \\
\text { Jones L L; } \\
\text { Vibuljan S }\end{array}$ & Tailândia & Investigação & $\begin{array}{l}\text { organic chemistry; } \\
\text { extraction; spatial } \\
\text { ability; anima- } \\
\text { tion; simulation; } \\
\text { visualization; mental } \\
\text { models; simulated } \\
\text { experiments; micro/ } \\
\text { macroscopic levels; } \\
\text { higher-/lower-order } \\
\text { cognitive skills; } \\
\text { particulate nature of } \\
\text { matter }\end{array}$ & $\begin{array}{l}\text { interações in- } \\
\text { termoleculares }\end{array}$ & $\begin{array}{l}\text { Entrevistas, Pré/ } \\
\text { Pós-testes, Likert }\end{array}$ & Não citada & Interativo \\
\hline $\begin{array}{l}\text { Chem. Educ. Res. } \\
\text { Pract. 2008, 9, } 11\end{array}$ & $\begin{array}{l}\text { Probing Student Teach- } \\
\text { ers' Subject Content } \\
\text { Knowledge In Chemis- } \\
\text { try: Case Studies Using } \\
\text { Dynamic Computer } \\
\text { Models }\end{array}$ & Toplis R & Reino Unido & Investigação & $\begin{array}{l}\text { models; animations; } \\
\text { misconceptions; } \\
\text { alternative fraworks }\end{array}$ & $\begin{array}{l}\text { ligação quími- } \\
\text { ca, reações }\end{array}$ & Entrevistas & $\begin{array}{l}\text { Outros, Grupo de } \\
\text { discussão, Trab- } \\
\text { alho em grupo }\end{array}$ & Interativo \\
\hline $\begin{array}{l}\text { Chem. Educ. Res. } \\
\text { Pract. 2008, 9, } 208\end{array}$ & $\begin{array}{l}\text { Learning Stoichiom- } \\
\text { etry: A Comparison Of } \\
\text { Text And Multimedia } \\
\text { Formats }\end{array}$ & $\begin{array}{l}\text { Evans K L; } \\
\text { Yaron D; } \\
\text { Leinhardt G }\end{array}$ & EUA & Investigação & $\begin{array}{l}\text { online instruc- } \\
\text { tion; cognitively } \\
\text { informed instruction; } \\
\text { randomized design; } \\
\text { stoichiometry; } \\
\text { virtual laboratory; } \\
\text { undergraduate } \\
\text { general chemistry }\end{array}$ & estequiometria & Pré/Pó-tTestes & $\begin{array}{l}\text { Outros, Outros, } \\
\text { Trabalho indi- } \\
\text { vidual }\end{array}$ & Interativo \\
\hline $\begin{array}{l}\text { Chem. Educ. Res. } \\
\text { Pract. 2009, 10, } 62\end{array}$ & $\begin{array}{l}\text { Visualization And } \\
\text { Interactivity In The } \\
\text { Teaching Of Chemistry } \\
\text { To Science And Non- } \\
\text { Science Students }\end{array}$ & $\begin{array}{l}\text { Venkataraman } \\
\text { B }\end{array}$ & EUA & Metodologia & $\begin{array}{c}\text { visualization; mo- } \\
\text { lecular modelling; } \\
\text { non-science majors; } \\
\text { assessment; mental } \\
\text { models } \\
\end{array}$ & vários & $\begin{array}{l}\text { Questionários: } \\
\text { quantitativo }\end{array}$ & $\begin{array}{l}\text { Trabalho em } \\
\text { grupo, Grupo de } \\
\text { discussão }\end{array}$ & Interativo \\
\hline $\begin{array}{l}\text { Chem. Educ. Res. } \\
\text { Pract. 2009, 10, } 296\end{array}$ & $\begin{array}{l}\text { Organicpad: An Interac- } \\
\text { tive Freehand Drawing } \\
\text { Application For Draw- } \\
\text { ing Lewis Structures } \\
\text { And The Development } \\
\text { Of Skills In Organic } \\
\text { Chemistry }\end{array}$ & $\begin{array}{l}\text { Cooper M } \\
\text { M; Grove N } \\
\text { P; Pargas R; } \\
\text { Bryfezynski S } \\
\text { P; Gatlin T }\end{array}$ & EUA & $\begin{array}{l}\text { Recurso } \\
\text { didático }\end{array}$ & $\begin{array}{c}\text { Lewis structures; } \\
\text { organic chemistry; } \\
\text { information technol- } \\
\text { ogy }\end{array}$ & $\begin{array}{l}\text { estrutura de } \\
\text { Lewis }\end{array}$ & $\begin{array}{l}\text { Não citada, Pré/ } \\
\text { Pós-testes }\end{array}$ & Não citada & Interativo \\
\hline $\begin{array}{l}\text { Chem. Educ. Res. } \\
\text { Pract. 2010, } 11,48\end{array}$ & $\begin{array}{l}\text { Continuous Symmetry } \\
\text { And Chemistry Teach- } \\
\text { ers: Learning Advanced } \\
\text { Chemistry Content } \\
\text { Through Novel Visual- } \\
\text { ization Tools }\end{array}$ & $\begin{array}{l}\text { Tuvi-Arad I; } \\
\text { Blonder R }\end{array}$ & Israel & Metodologia & $\begin{array}{l}\text { symmetry, con- } \\
\text { tinuous symmetry; } \\
\text { chemistry teachers; } \\
\text { content knowledge; } \\
\text { professional devel- } \\
\text { opment; molecular } \\
\text { visualization } \\
\end{array}$ & simetria & $\begin{array}{l}\text { Entrevistas, } \\
\text { Vídeo/Áudio, } \\
\text { Questionários: } \\
\text { quantitativo }\end{array}$ & $\begin{array}{c}\text { Trabalho em } \\
\text { grupo, Grupo de } \\
\text { discussão, Aula } \\
\text { expositiva, Outros }\end{array}$ & Interativo \\
\hline $\begin{array}{l}\text { Chem. Educ. Res. } \\
\text { Pract. 2010, 11, } 154\end{array}$ & $\begin{array}{l}\text { Student-Generated } \\
\text { Submicro Diagrams: } \\
\text { A Useful Tool For } \\
\text { Teaching And Learning } \\
\text { Chemical Equations } \\
\text { And Stoichiometry }\end{array}$ & $\begin{array}{l}\text { Davidowitz B; } \\
\text { Chittleborough } \\
\text { G; Murray E }\end{array}$ & $\begin{array}{l}\text { África do } \\
\text { Sul }\end{array}$ & Metodologia & $\begin{array}{c}\text { chemical equations; } \\
\text { stoichiometry; } \\
\text { submicroscopic } \\
\text { diagrams; represen- } \\
\text { tations }\end{array}$ & estequiometria & $\begin{array}{l}\text { Questionários: } \\
\text { quantitativo, } \\
\text { Desenho }\end{array}$ & $\begin{array}{l}\text { Trabalho em } \\
\text { grupo }\end{array}$ & $\begin{array}{l}\text { Ilustração } \\
\text { em papel }\end{array}$ \\
\hline
\end{tabular}


Tabela 1S. Dados a partir dos quais se realizou o estudo (continuação)

\begin{tabular}{|c|c|c|c|c|c|c|c|c|c|}
\hline Ref. & Título & Autores & $\begin{array}{l}\text { País da } \\
\text { instituição } \\
\text { do } 1^{\circ} \text { autor }\end{array}$ & Tipo de artigo & Palavras-chave & $\begin{array}{l}\text { Conceitos } \\
\text { (até 2) }\end{array}$ & $\begin{array}{l}\text { Metodologia de } \\
\text { pesquisa (até 4) }\end{array}$ & $\begin{array}{c}\text { Metodologia } \\
\text { usada no contexto } \\
\text { educacional } \\
\text { (até 5) }\end{array}$ & $\begin{array}{c}\text { Meio } \\
\text { suporte } \\
\text { didático } 1 \\
\text { (até 3) }\end{array}$ \\
\hline $\begin{array}{l}\text { Chem. Educ. Res. } \\
\text { Pract. 2010, } 11,43\end{array}$ & $\begin{array}{l}\text { Origami: A Versatile } \\
\text { Modeling System For } \\
\text { Visualising Chemical } \\
\text { Structure And Explor- } \\
\text { ing Molecular Function }\end{array}$ & $\begin{array}{l}\text { Davis J; Leslie } \\
\text { R; Billington } \\
\text { S; Slater P R }\end{array}$ & Reino Unido & $\begin{array}{l}\text { Recurso } \\
\text { didático }\end{array}$ & $\begin{array}{l}\text { origami; models; } \\
\text { shape; modeling; } \\
\text { molecular shape; } \\
\text { visualization }\end{array}$ & $\begin{array}{l}\text { estrutura } \\
\text { molecular, inte- } \\
\text { rações intermo- } \\
\text { leculares }\end{array}$ & $\begin{array}{l}\text { Questionários: } \\
\text { quantitativo }\end{array}$ & $\begin{array}{l}\text { Trabalho em } \\
\text { grupo, Outros }\end{array}$ & $\begin{array}{l}\text { Modelos } \\
\text { físicos }\end{array}$ \\
\hline $\begin{array}{l}\text { Comput. Educ. } \\
\mathbf{2 0 0 7}, 48,30\end{array}$ & $\begin{array}{l}\text { Transition From Tradi- } \\
\text { tional To Ict-Enhanced } \\
\text { Learning Environments } \\
\text { In Undergraduate } \\
\text { Chemistry Courses }\end{array}$ & Barak M & Israel & $\begin{array}{l}\text { Recurso } \\
\text { didático }\end{array}$ & $\begin{array}{l}\text { improving classroom } \\
\text { teaching; post- } \\
\text { secondary education; } \\
\text { visualization; } \\
\text { teaching/learning } \\
\text { strategies }\end{array}$ & $\begin{array}{l}\text { estrutura } \\
\text { molecular }\end{array}$ & $\begin{array}{c}\text { Entrevistas, } \\
\text { Fórum eletrônico/ } \\
\text { e-mail }\end{array}$ & $\begin{array}{l}\text { Trabalho em } \\
\text { grupo, Grupo de } \\
\text { discussão }\end{array}$ & Interativo \\
\hline $\begin{array}{l}\text { Comput. Educ. } \\
\mathbf{2 0 0 8}, 51,519\end{array}$ & $\begin{array}{l}\text { How Science Students } \\
\text { Can Learn About Un- } \\
\text { observable Phenomena } \\
\text { Using Computer-Based } \\
\text { Analogies }\end{array}$ & $\begin{array}{l}\text { Trey L; } \\
\text { Khan S }\end{array}$ & Canadá & Investigação & $\begin{array}{l}\text { simulations; multi- } \\
\text { media/hypermedia } \\
\text { systems; interactive } \\
\text { learning environ- } \\
\text { ments; teaching } \\
\text { strategies/learning } \\
\text { strategies }\end{array}$ & equilíbrio & $\begin{array}{l}\text { Questionários: } \\
\text { quantitativo, } \\
\text { Desenho }\end{array}$ & $\begin{array}{l}\text { Trabalho indi- } \\
\text { vidual }\end{array}$ & $\begin{array}{l}\text { Interativo, } \\
\text { Ilustração } \\
\text { eletrônica }\end{array}$ \\
\hline $\begin{array}{l}\text { Comput. Educ. } \\
\mathbf{2 0 0 8}, 51,423\end{array}$ & $\begin{array}{l}\text { The Influence Of } \\
\text { Computer-Assisted In- } \\
\text { struction On Students' } \\
\text { Conceptual Under- } \\
\text { standing Of Chemical } \\
\text { Bonding And Attitude } \\
\text { Toward Chemistry: A } \\
\text { Case For Turkey }\end{array}$ & Özmen H & Turquia & Investigação & $\begin{array}{l}\text { computer-assisted } \\
\text { instruction; chemical } \\
\text { bonding; attitude; } \\
\text { alternative concep- } \\
\text { tion }\end{array}$ & ligação química & $\begin{array}{c}\text { Pré/Pós-testes, } \\
\text { Likert }\end{array}$ & $\begin{array}{l}\text { Trabalho em } \\
\text { grupo, Trabalho } \\
\text { individual }\end{array}$ & Interativo \\
\hline $\begin{array}{l}\text { Comput. Educ. } \\
\mathbf{2 0 0 8}, 51,584\end{array}$ & $\begin{array}{l}\text { Full Immersive Virtual } \\
\text { Environment Cavetm In } \\
\text { Chemistry Education }\end{array}$ & $\begin{array}{c}\text { Limniou M; } \\
\text { Roberts D; } \\
\text { Papadopoulos } \\
\text { N } \\
\end{array}$ & Reino Unido & Metodologia & $\begin{array}{l}\text { interactive learning } \\
\text { environment; vurtual } \\
\text { reality; improving } \\
\text { classroom teaching }\end{array}$ & reações & Pré/Pós-testes & $\begin{array}{c}\text { Trabalho em } \\
\text { grupo }\end{array}$ & $\begin{array}{c}\text { Outros, } \\
\text { Animação }\end{array}$ \\
\hline $\begin{array}{l}\text { Comput. Educ. } \\
\mathbf{2 0 0 9}, 53,853\end{array}$ & $\begin{array}{l}\text { Effectiveness Of A } \\
\text { Virtual Laboratory As } \\
\text { A Preparatory Resource } \\
\text { For Distance Education } \\
\text { Chemistry Students }\end{array}$ & $\begin{array}{l}\text { Dalgarno B; } \\
\text { Bishop A G; } \\
\text { Adlong W; } \\
\text { Bedgood Jr } \\
\text { D R }\end{array}$ & Austrália & Investigação & $\begin{array}{c}\text { virtual real- } \\
\text { ity; simulations; } \\
\text { interactive learning } \\
\text { environments; } \\
\text { distance education; } \\
\text { post-secondary } \\
\text { education; chemistry } \\
\text { education } \\
\end{array}$ & $\begin{array}{l}\text { Trabalho em } \\
\text { laboratório }\end{array}$ & $\begin{array}{l}\text { Likert, Entrevis- } \\
\text { tas, Pré/Pós-testes }\end{array}$ & $\begin{array}{c}\text { Outros, Trabalho } \\
\text { em laboratório, } \\
\text { Trabalho indi- } \\
\text { vidual }\end{array}$ & Interativo \\
\hline $\begin{array}{l}\text { Comput. Educ. } \\
\mathbf{2 0 0 9}, 52,390\end{array}$ & $\begin{array}{l}\text { 3D Visualization Types } \\
\text { In Multimedia Ap- } \\
\text { plications For Science } \\
\text { Learning: A Case Study } \\
\text { For } 8 \text { Th Grade Students } \\
\text { In Greece }\end{array}$ & $\begin{array}{l}\text { Korakakis G; } \\
\text { Pavlatou E A; } \\
\text { Spyrellis N }\end{array}$ & Grécia & Investigação & $\begin{array}{l}\text { secondary education; } \\
\text { media in education; } \\
\text { multimedia/hy- } \\
\text { permedia systems; } \\
\text { simulations }\end{array}$ & $\begin{array}{l}\text { separação de } \\
\text { misturas }\end{array}$ & Pré/Pós-testes & $\begin{array}{l}\text { Trabalho indi- } \\
\text { vidual }\end{array}$ & $\begin{array}{l}\text { Interativo, } \\
\text { Ilustração } \\
\text { eletrônica, } \\
\text { Animação }\end{array}$ \\
\hline $\begin{array}{l}\text { Comput. Educ. } \\
\mathbf{2 0 0 9}, 52,681\end{array}$ & $\begin{array}{l}\text { The Effects Of Con- } \\
\text { ceptual Change Texts } \\
\text { Accompanied With } \\
\text { Animations On Over- } \\
\text { coming 11Th Grade } \\
\text { Students' Alternative } \\
\text { Conceptions Of Chemi- } \\
\text { cal Bonding }\end{array}$ & $\begin{array}{c}\text { Özmen H; } \\
\text { Demircioglu } \\
\text { H; } \\
\text { Demircioglu } \\
\text { G }\end{array}$ & Turquia & Investigação & $\begin{array}{l}\text { conceptual change } \\
\text { texts; animations; al- } \\
\text { ternative conception; } \\
\text { chemical bonding }\end{array}$ & ligação química & Pré/Pós-testes & $\begin{array}{l}\text { Trabalho em } \\
\text { grupo, Grupo de } \\
\text { discussão, Trab- } \\
\text { alho individual }\end{array}$ & Interativo \\
\hline $\begin{array}{l}\text { Comput. Educ. } \\
\mathbf{2 0 0 9}, 52,45\end{array}$ & $\begin{array}{l}\text { Integration Of Simula- } \\
\text { tion Into Pre-Labora- } \\
\text { tory Chemical Course: } \\
\text { Computer Cluster } \\
\text { Versus Webct }\end{array}$ & $\begin{array}{c}\text { Limniou M; } \\
\text { Papadopoulos } \\
\text { N; Whitehead } \\
\text { C }\end{array}$ & Reino Unido & Investigação & $\begin{array}{c}\text { simulations; } \\
\text { teaching/learning } \\
\text { strategies; interactive } \\
\text { learning environ- } \\
\text { ments; cooperative/ } \\
\text { collaborative learn- } \\
\text { ing; improving class- } \\
\text { room teaching }\end{array}$ & titulação & $\begin{array}{l}\text { Questionários: } \\
\text { quantitativo }\end{array}$ & $\begin{array}{l}\text { Outros, Grupo de } \\
\text { discussão, Trab- } \\
\text { alho em grupo, } \\
\text { Trabalho indi- } \\
\text { vidual, Trabalho } \\
\text { em laboratório }\end{array}$ & Interativo \\
\hline $\begin{array}{l}\text { Int. J. Sci. Educ. } \\
\text { 2001, 23, } 1303\end{array}$ & $\begin{array}{l}\text { The Impact Of } \\
\text { Concept Mapping And } \\
\text { Visualization On The } \\
\text { Learning Of Secondary } \\
\text { School Chemistry } \\
\text { Students }\end{array}$ & $\begin{array}{c}\text { Brandt L; Elen } \\
\text { J; Hellemans } \\
\text { J; Heerman L; } \\
\text { Couwenberg } \\
\text { I; Volckaert L; } \\
\text { Morisse H } \\
\end{array}$ & Bélgica & Investigação & Não citadas & eletroquímica & Pré/Pós-testes & $\begin{array}{l}\text { Aula expositiva, } \\
\text { Trabalho indi- } \\
\text { vidual }\end{array}$ & $\begin{array}{l}\text { Ilustração } \\
\text { em papel }\end{array}$ \\
\hline $\begin{array}{l}\text { Int. J. Sci. Educ. } \\
\mathbf{2 0 0 3}, 25,1353\end{array}$ & $\begin{array}{l}\text { The Role Of Submicro- } \\
\text { scopic And Symbolic } \\
\text { Representations In } \\
\text { Chemical Explanations }\end{array}$ & $\begin{array}{c}\text { Treagust D F; } \\
\text { Chittleborough } \\
\text { G; Mamiala } \\
\text { T L } \\
\end{array}$ & Austrália & Metodologia & Não citadas & vários & $\begin{array}{l}\text { Entrevistas, } \\
\text { Vídeo/Áudio }\end{array}$ & $\begin{array}{l}\text { Trabalho em } \\
\text { grupo, Grupo de } \\
\text { discussão, Aula } \\
\text { expositiva }\end{array}$ & $\begin{array}{l}\text { Modelos } \\
\text { físicos }\end{array}$ \\
\hline $\begin{array}{l}\text { Int. J. Sci. Educ. } \\
\mathbf{2 0 0 3}, 25,329\end{array}$ & $\begin{array}{l}\text { Spatial Ability And The } \\
\text { Impact Of Visualiza- } \\
\text { tion/Animation On } \\
\text { Learning Electrochem- } \\
\text { istry }\end{array}$ & $\begin{array}{c}\text { Yang E; Andre } \\
\text { T; Greenbowe } \\
\text { T J; Tibell L }\end{array}$ & EUA & Investigação & Não citadas & eletroquímica & $\begin{array}{l}\text { Questionários: } \\
\text { quantitativo, } \\
\text { Pré/Pós-testes, } \\
\text { Desenho }\end{array}$ & $\begin{array}{c}\text { Aula expositiva, } \\
\text { Trabalho indi- } \\
\text { vidual }\end{array}$ & $\begin{array}{l}\text { Interativo, } \\
\text { Ilustração } \\
\text { eletrônica }\end{array}$ \\
\hline
\end{tabular}


Tabela 1S. Dados a partir dos quais se realizou o estudo (continuação)

\begin{tabular}{|c|c|c|c|c|c|c|c|c|c|}
\hline Ref. & Título & Autores & $\begin{array}{l}\text { País da } \\
\text { instituição } \\
\text { do } 1^{\circ} \text { autor }\end{array}$ & Tipo de artigo & Palavras-chave & $\begin{array}{l}\text { Conceitos } \\
\text { (até 2) }\end{array}$ & $\begin{array}{l}\text { Metodologia de } \\
\text { pesquisa (até 4) }\end{array}$ & $\begin{array}{c}\text { Metodologia } \\
\text { usada no contexto } \\
\text { educacional } \\
\text { (até 5) }\end{array}$ & $\begin{array}{l}\text { Meio } \\
\text { suporte } \\
\text { didático } 1 \\
\text { (até 3) }\end{array}$ \\
\hline $\begin{array}{l}\text { Int. J. Sci. Educ. } \\
\text { 2005, 27, } 1269\end{array}$ & $\begin{array}{l}\text { Using Static And } \\
\text { Dynamic Visuals To } \\
\text { Represent Chemical } \\
\text { Change At Molecular } \\
\text { Level }\end{array}$ & $\begin{array}{c}\text { Ardac D; } \\
\text { Akaygun S }\end{array}$ & Turquia & Investigação & Não citadas & $\begin{array}{l}\text { Natureza partic- } \\
\text { ular da matéria, } \\
\text { reações }\end{array}$ & $\begin{array}{l}\text { Questionários: } \\
\text { quantitativo, } \\
\text { Desenho }\end{array}$ & $\begin{array}{l}\text { Trabalho indi- } \\
\text { vidual, Grupo de } \\
\text { discussão }\end{array}$ & $\begin{array}{l}\text { Animação, } \\
\text { Ilustração } \\
\text { eletrônica }\end{array}$ \\
\hline $\begin{array}{l}\text { Int. J. Sci. Educ. } \\
\mathbf{2 0 0 9}, 31,787\end{array}$ & $\begin{array}{l}\text { Multiple Representa- } \\
\text { tion In Learning About } \\
\text { Evaporation }\end{array}$ & $\begin{array}{l}\text { Prain V; Tytler } \\
\text { R; Peterson S }\end{array}$ & Austrália & Metodologia & Não citadas & $\begin{array}{l}\text { Natureza } \\
\text { particular da } \\
\text { matéria }\end{array}$ & $\begin{array}{l}\text { Entrevistas, } \\
\text { Questionários: } \\
\text { qualitativo, De- } \\
\text { senho }\end{array}$ & $\begin{array}{l}\text { Outros, Trabalho } \\
\text { em grupo, Grupo } \\
\text { de discussão }\end{array}$ & $\begin{array}{l}\text { Modelos } \\
\text { físicos, Il- } \\
\text { ustração em } \\
\text { papel }\end{array}$ \\
\hline $\begin{array}{l}\text { Int. J. Sci. Educ. } \\
\mathbf{2 0 0 9}, 31,603\end{array}$ & $\begin{array}{l}\text { Learning Of Chemical } \\
\text { Equilibrium Through } \\
\text { Modelling-Based } \\
\text { Teaching }\end{array}$ & $\begin{array}{l}\text { Maia P F; } \\
\text { Justi R }\end{array}$ & Brasil & Metodologia & Não citadas & equilíbrio & $\begin{array}{l}\text { Vídeo/Áudio, } \\
\text { Questionários: } \\
\text { qualitativo, De- } \\
\text { senho }\end{array}$ & $\begin{array}{l}\text { Outros, Trabalho } \\
\text { em grupo, Grupo } \\
\text { de discussão, } \\
\text { Trabalho em } \\
\text { laboratório }\end{array}$ & $\begin{array}{l}\text { Modelos } \\
\text { físicos, Il- } \\
\text { ustração em } \\
\text { papel }\end{array}$ \\
\hline $\begin{array}{l}\text { Int. J. Sci. Educ. } \\
\mathbf{2 0 0 9}, 31,1743\end{array}$ & $\begin{array}{l}\text { Impacts Of Multi-Rep- } \\
\text { resentational Instruction } \\
\text { On High School } \\
\text { Students' Conceptual } \\
\text { Understandings Of The } \\
\text { Particulate Nature Of } \\
\text { Matter }\end{array}$ & $\begin{array}{l}\text { Adadan E; } \\
\text { Irving K E; } \\
\text { Trundle K C }\end{array}$ & Turquia & Investigação & Não citadas & $\begin{array}{l}\text { Natureza } \\
\text { particular da } \\
\text { matéria }\end{array}$ & $\begin{array}{l}\text { Questionários: } \\
\text { qualitativo, Ent- } \\
\text { revistas, Desenho }\end{array}$ & $\begin{array}{c}\text { Aula exposi- } \\
\text { tiva, Trabalho em } \\
\text { grupo, Grupo de } \\
\text { discussão }\end{array}$ & $\begin{array}{l}\text { Interativo, } \\
\text { Ilustração } \\
\text { eletrônica }\end{array}$ \\
\hline $\begin{array}{l}\text { J. Chem. Educ. } \\
\text { 2001, 78, } 837\end{array}$ & $\begin{array}{l}\text { A Computer-Assisted } \\
\text { Tutorial On Protein } \\
\text { Structure }\end{array}$ & Tsai C S & Canadá & $\begin{array}{l}\text { Recurso } \\
\text { didático }\end{array}$ & $\begin{array}{c}\text { upper-division } \\
\text { undergraduate; } \\
\text { biochemistry; com- } \\
\text { puter bulletin board; } \\
\text { computer-based } \\
\text { learning; proteins/ } \\
\text { peptides }\end{array}$ & proteínas & Não citada & Não citada & Interativo \\
\hline $\begin{array}{l}\text { J. Chem. Educ. } \\
\text { 2001, 78, } 840\end{array}$ & $\begin{array}{l}\text { Integrating Molecular } \\
\text { Modeling Into The } \\
\text { Inorganic Chemistry } \\
\text { Laboratory }\end{array}$ & $\begin{array}{c}\text { Montgomery } \\
\text { C D }\end{array}$ & Canadá & $\begin{array}{l}\text { Recurso } \\
\text { didático }\end{array}$ & $\begin{array}{l}\text { second-year } \\
\text { undergraduate; labo- } \\
\text { ratory instruction; } \\
\text { molecular modeling } \\
\text { exercises and experi- } \\
\text { ments; computer- } \\
\text { based learning; } \\
\text { computational } \\
\text { chemistry }\end{array}$ & $\begin{array}{l}\text { estrutura } \\
\text { molecular }\end{array}$ & Não citada & $\begin{array}{l}\text { Trabalho em } \\
\text { laboratório }\end{array}$ & Interativo \\
\hline $\begin{array}{l}\text { J. Chem. Educ. } \\
\text { 2001, 78, } 1560\end{array}$ & $\begin{array}{l}\text { Spec Uv-Vis: An } \\
\text { Ultraviolet-Visible } \\
\text { Spectrophotometer } \\
\text { Simulation }\end{array}$ & $\begin{array}{l}\text { Papadopoulos } \\
\text { N; Limniou } \\
\text { M; } \\
\text { Koklamanis } \\
\text { G; Tsarouxas } \\
\text { A; Roilidis M; } \\
\text { Bigger S W }\end{array}$ & Grécia & $\begin{array}{l}\text { Recurso } \\
\text { didático }\end{array}$ & $\begin{array}{c}\text { second-year } \\
\text { undergraduate; } \\
\text { analytical chemistry; } \\
\text { computer-based } \\
\text { learning; UV-VIS } \\
\text { spectrocopy }\end{array}$ & espectroscopia & Não citada & Não citada & Interativo \\
\hline $\begin{array}{l}\text { J. Chem. Educ. } \\
\text { 2001, 78, } 121\end{array}$ & $\begin{array}{l}\text { Teaching } 1 \mathrm{H} \mathrm{Nmr} \\
\text { Spectrometry Using } \\
\text { Computer Modeling }\end{array}$ & $\begin{array}{l}\text { Habata Y; } \\
\text { Akabori Y }\end{array}$ & Japão & $\begin{array}{l}\text { Recurso } \\
\text { didático }\end{array}$ & $\begin{array}{l}\text { second-year under- } \\
\text { graduate; organic } \\
\text { chemistry; teaching } \\
\text { with technology; } \\
\text { computer-based } \\
\text { learning; molecular } \\
\text { properties/structure }\end{array}$ & espectroscopia & Não citada & Não citada & Interativo \\
\hline $\begin{array}{l}\text { J. Chem. Educ. } \\
\text { 2001, 78, } 420\end{array}$ & $\begin{array}{l}\text { Which Nitrogen? } \\
\text { Combining Computer } \\
\text { Modeling With Labora- } \\
\text { tory Work In Organic } \\
\text { Chemistry }\end{array}$ & Hull L A & EUA & $\begin{array}{l}\text { Recurso } \\
\text { didático }\end{array}$ & $\begin{array}{l}\text { upper-division un- } \\
\text { dergraduate; organic } \\
\text { chemistry; molecular } \\
\text { modeling exercises } \\
\text { and experiments; } \\
\text { inquiry-based/ } \\
\text { discovery learning; } \\
\text { laboratory comput- } \\
\text { ing/interfacing }\end{array}$ & espectroscopia & Não citada & $\begin{array}{l}\text { Trabalho em } \\
\text { laboratório }\end{array}$ & Interativo \\
\hline $\begin{array}{l}\text { J. Chem. Educ. } \\
\text { 2001, 78, } 824\end{array}$ & $\begin{array}{l}\text { Spektri-Sim: Interactive } \\
\text { Simulation And Analy- } \\
\text { sis Of The Infrared } \\
\text { Spectra Of Diatomic } \\
\text { Molecules }\end{array}$ & $\begin{array}{l}\text { Glendening E } \\
\text { D; Kansanoho } \\
\text { J M }\end{array}$ & EUA & $\begin{array}{l}\text { Recurso } \\
\text { didático }\end{array}$ & $\begin{array}{l}\text { second-year under- } \\
\text { graduate; physical } \\
\text { chemistry; comput- } \\
\text { er-based learning; IR } \\
\text { spectroscopy }\end{array}$ & espectroscopia & Não citada & $\begin{array}{l}\text { Trabalho em } \\
\text { laboratório }\end{array}$ & Interativo \\
\hline $\begin{array}{l}\text { J. Chem. Educ. } \\
\text { 2001, 78, } 1195\end{array}$ & $\begin{array}{l}\text { From The Wood-Shop } \\
\text { To Crystal Engineering: } \\
\text { Teaching Three-Dimen- } \\
\text { sional Chemistry }\end{array}$ & Martin J D & EUA & Metodologia & $\begin{array}{l}\text { upper-division } \\
\text { undergraduate; } \\
\text { inorganic chemistry; } \\
\text { computer-based } \\
\text { learning; crystals/ } \\
\text { crystallography } \\
\end{array}$ & $\begin{array}{l}\text { estrutura } \\
\text { molecular }\end{array}$ & Desenho & Não citada & $\begin{array}{l}\text { Ilustração } \\
\text { em papel }\end{array}$ \\
\hline $\begin{array}{l}\text { J. Chem. Educ. } \\
\text { 2001, 78, } 1412\end{array}$ & $\begin{array}{l}\text { Using Computer-Based } \\
\text { Visualization Strategies } \\
\text { To Improve Students' } \\
\text { Understanding Of } \\
\text { Molecular Polarity And } \\
\text { Miscibility }\end{array}$ & $\begin{array}{l}\text { Sanger M J; } \\
\text { Badger S M }\end{array}$ & EUA & Investigação & $\begin{array}{c}\text { first-year } \\
\text { undergraduate/ } \\
\text { general; chemical } \\
\text { education research; } \\
\text { multimedia-based } \\
\text { learning; molecular } \\
\text { properties/structure }\end{array}$ & $\begin{array}{l}\text { polaridade, } \\
\text { interações in- } \\
\text { termoleculares }\end{array}$ & $\begin{array}{l}\text { Pré/Pós-testes, } \\
\text { Questionários: } \\
\text { quantitativo }\end{array}$ & $\begin{array}{l}\text { Trabalho em } \\
\text { laboratório }\end{array}$ & $\begin{array}{l}\text { Interativo, } \\
\text { Modelos } \\
\text { físicos, Il- } \\
\text { ustração } \\
\text { eletrônica }\end{array}$ \\
\hline
\end{tabular}


Tabela 1S. Dados a partir dos quais se realizou o estudo (continuação)

\begin{tabular}{|c|c|c|c|c|c|c|c|c|c|}
\hline Ref. & Título & Autores & $\begin{array}{l}\text { País da } \\
\text { instituição } \\
\text { do } 1^{\circ} \text { autor }\end{array}$ & Tipo de artigo & Palavras-chave & $\begin{array}{l}\text { Conceitos } \\
\text { (até 2) }\end{array}$ & $\begin{array}{l}\text { Metodologia de } \\
\text { pesquisa (até 4) }\end{array}$ & $\begin{array}{c}\text { Metodologia } \\
\text { usada no contexto } \\
\text { educacional } \\
\text { (até 5) }\end{array}$ & $\begin{array}{c}\text { Meio } \\
\text { suporte } \\
\text { didático 1 } \\
\text { (até 3) }\end{array}$ \\
\hline $\begin{array}{l}\text { J. Chem. Educ. } \\
\text { 2001, } 78,1487\end{array}$ & $\begin{array}{l}\text { An Early Emphasis } \\
\text { On Symmetry And A } \\
\text { Three-Dimensional } \\
\text { Perspective In The } \\
\text { Chemistry Curriculum }\end{array}$ & $\begin{array}{c}\text { Mc Kay S E; } \\
\text { Boone S R }\end{array}$ & EUA & Metodologia & $\begin{array}{l}\text { second-year } \\
\text { undergraduate; } \\
\text { curriculum; group } \\
\text { theory/symmetry }\end{array}$ & simetria & $\begin{array}{l}\text { Questionários: } \\
\text { quantitativo }\end{array}$ & Aula expositiva & Outros \\
\hline $\begin{array}{l}\text { J. Chem. Educ. } \\
\mathbf{2 0 0 1}, 78,1551\end{array}$ & $\begin{array}{l}\text { Integrating Computa- } \\
\text { tional Chemistry Into } \\
\text { A Project-Oriented } \\
\text { Biochemistry Labora- } \\
\text { tory Experience: A } \\
\text { New Twist On The } \\
\text { Lysozyme Experiment }\end{array}$ & $\begin{array}{l}\text { Peterson R R; } \\
\text { Cox J R }\end{array}$ & EUA & Metodologia & $\begin{array}{l}\text { upper-division } \\
\text { undergraduate; } \\
\text { biochemistry; com- } \\
\text { puter bulletin board; } \\
\text { hands-on learning/ } \\
\text { manipulatives; } \\
\text { carbohydrates }\end{array}$ & proteínas & Não citada & $\begin{array}{l}\text { Trabalho em } \\
\text { grupo }\end{array}$ & Interativo \\
\hline $\begin{array}{l}\text { J. Chem. Educ. } \\
\mathbf{2 0 0 2}, 79,588\end{array}$ & $\begin{array}{l}\text { Teaching Bonding In } \\
\text { Organometallic Chem- } \\
\text { istry Using Computa- } \\
\text { tional Chemistry }\end{array}$ & $\begin{array}{c}\text { Haaren R J; } \\
\text { Reek J N H; } \\
\text { Oevering H; } \\
\text { Coussens B B; } \\
\text { Strijdonck G P } \\
\text { F; Kamer P C } \\
\text { J; Leeuwen P } \\
\text { W N M } \\
\end{array}$ & Holanda & $\begin{array}{l}\text { Recurso } \\
\text { didático }\end{array}$ & Não citadas & $\begin{array}{l}\text { estrutura } \\
\text { molecular }\end{array}$ & Não citada & Não citada & Interativo \\
\hline $\begin{array}{l}\text { J. Chem. Educ. } \\
\mathbf{2 0 0 2}, 79,640\end{array}$ & $\begin{array}{l}\text { Le Chat: Simulation In } \\
\text { Chemical Equilibrium }\end{array}$ & $\begin{array}{l}\text { Paiva J C M; } \\
\text { Gil V M S; } \\
\text { Correia A F }\end{array}$ & Portugal & $\begin{array}{l}\text { Recurso } \\
\text { didático }\end{array}$ & Não citadas & equilíbrio & Não citada & Não citada & Interativo \\
\hline $\begin{array}{l}\text { J. Chem. Educ. } \\
\mathbf{2 0 0 2}, 79,468\end{array}$ & $\begin{array}{l}\text { Crystal Models Made } \\
\text { From Clear Plastic } \\
\text { Boxes And Their Use } \\
\text { In Determining Avoga- } \\
\text { dro'S Number }\end{array}$ & Bindel T H & EUA & $\begin{array}{l}\text { Recurso } \\
\text { didático }\end{array}$ & $\begin{array}{l}\text { high school/intro- } \\
\text { ductory chemistry; } \\
\text { crystals/crystal- } \\
\text { lography }\end{array}$ & $\begin{array}{l}\text { estrutura } \\
\text { molecular }\end{array}$ & Não citada & Não citada & $\begin{array}{l}\text { Modelos } \\
\text { físicos }\end{array}$ \\
\hline $\begin{array}{l}\text { J. Chem. Educ. } \\
\mathbf{2 0 0 2}, 79,638\end{array}$ & $\begin{array}{l}\text { Kinsimxp, A Chemical } \\
\text { Kinetics Simulation }\end{array}$ & $\begin{array}{l}\text { Allendoerfer } \\
\text { R D }\end{array}$ & EUA & $\begin{array}{l}\text { Recurso } \\
\text { didático }\end{array}$ & Não citadas & cinética & Não citada & Não citada & Interativo \\
\hline $\begin{array}{l}\text { J. Chem. Educ. } \\
\text { 2002, 79, } 1088\end{array}$ & $\begin{array}{l}\text { A Three-Dimensional } \\
\text { Model For Water }\end{array}$ & $\begin{array}{c}\text { Johnson J L } \\
\text { H; Yalkowsky } \\
\text { S H; Vitz E }\end{array}$ & EUA & $\begin{array}{l}\text { Recurso } \\
\text { didático }\end{array}$ & $\begin{array}{l}\text { high school/intro- } \\
\text { ductory chemistry; } \\
\text { demonstrations; } \\
\text { tested demonstra- } \\
\text { tions; aqueous solu- } \\
\text { tion chemistry }\end{array}$ & $\begin{array}{l}\text { estrutura } \\
\text { molecular, inte- } \\
\text { rações intermo- } \\
\quad \text { leculares }\end{array}$ & Não citada & Não citada & $\begin{array}{l}\text { Modelos } \\
\text { físicos }\end{array}$ \\
\hline $\begin{array}{l}\text { J. Chem. Educ. } \\
\mathbf{2 0 0 2}, 79,1372\end{array}$ & $\begin{array}{l}\text { Using Computer Graph- } \\
\text { ics To Demonstrate The } \\
\text { Origin And Applica- } \\
\text { tions Of The "Reacting } \\
\text { Bond Rules" }\end{array}$ & $\begin{array}{l}\text { Tyler D R; } \\
\text { Herrick D R }\end{array}$ & EUA & $\begin{array}{l}\text { Recurso } \\
\text { didático }\end{array}$ & $\begin{array}{l}\text { upper-division } \\
\text { undergraduate; } \\
\text { physical chemistry; } \\
\text { computer bulletin } \\
\text { board; computer- } \\
\text { based learning; } \\
\text { computacional } \\
\text { chemistry }\end{array}$ & reações & Não citada & Não citada & Interativo \\
\hline $\begin{array}{l}\text { J. Chem. Educ. } \\
\text { 2002, 79, } 1379\end{array}$ & $\begin{array}{l}\text { Webware For Class- } \\
\text { room, Computer Room, } \\
\text { Student'S Room }\end{array}$ & Hanson R M & EUA & $\begin{array}{l}\text { Recurso } \\
\text { didático }\end{array}$ & $\begin{array}{c}\text { upper-division un- } \\
\text { dergraduate; physi- } \\
\text { cal chemistry; JCE } \\
\text { WebWare; internet/ } \\
\text { web-based learning; } \\
\text { MO theory }\end{array}$ & cinética & Não citada & Não citada & Interativo \\
\hline $\begin{array}{l}\text { J. Chem. Educ. } \\
\text { 2003, } 80,709\end{array}$ & $\begin{array}{l}\text { General Chemistry Col- } \\
\text { lection, 7Th Edition }\end{array}$ & $\begin{array}{l}\text { Papadopoulos } \\
\mathrm{N} ; \text { Limniou M }\end{array}$ & Grécia & $\begin{array}{l}\text { Recurso } \\
\text { didático }\end{array}$ & $\begin{array}{l}\text { high school/intro- } \\
\text { ductory chemistry; } \\
\text { analytical chemistry; } \\
\text { JCE software; com- } \\
\text { puter-based learning; } \\
\text { acids/bases }\end{array}$ & titulação & Não citada & Não citada & Interativo \\
\hline $\begin{array}{l}\text { J. Chem. Educ. } \\
\text { 2003, } 80,1222\end{array}$ & 3Dnormalmodes & $\begin{array}{l}\text { Sigalas M P; } \\
\text { Charistos N } \\
\text { D; Teberekidis } \\
\text { V I; Tsipis } \\
\text { C A; }\end{array}$ & Grécia & $\begin{array}{l}\text { Recurso } \\
\text { didático }\end{array}$ & $\begin{array}{c}\text { second-year } \\
\text { undergraduate; JCE } \\
\text { software; computer- } \\
\text { based learning; IR } \\
\text { spectroscopy } \\
\end{array}$ & espectroscopia & Não citada & Não citada & Interativo \\
\hline $\begin{array}{l}\text { J. Chem. Educ. } \\
\mathbf{2 0 0 3}, 80,582\end{array}$ & $\begin{array}{l}\text { Web-Based Computa- } \\
\text { tions And Animations }\end{array}$ & $\begin{array}{l}\text { Borkent } \\
\text { H; Rooij J; } \\
\text { Stueker O; } \\
\text { Brunberg I; } \\
\text { Fels G }\end{array}$ & Holanda & $\begin{array}{l}\text { Recurso } \\
\text { didático }\end{array}$ & $\begin{array}{c}\text { second-year } \\
\text { undergraduate; } \\
\text { organic chemistry; } \\
\text { JCE WebWare: web- } \\
\text { based learning aids; } \\
\text { internet/web-based } \\
\text { learning; computa- } \\
\text { tional chemistry }\end{array}$ & vários & Não citada & Não citada & Interativo \\
\hline $\begin{array}{l}\text { J. Chem. Educ. } \\
\mathbf{2 0 0 3}, 80,346\end{array}$ & $\begin{array}{l}\text { Learning In Chemistry } \\
\text { With Virtual Labora- } \\
\text { tories }\end{array}$ & $\begin{array}{c}\text { Martínez- } \\
\text { Jiménez P; } \\
\text { Pontes- } \\
\text { Pedrajas } \\
\text { A; Polo J; } \\
\text { Climent- } \\
\text { Bellido M S }\end{array}$ & Espanha & Investigação & $\begin{array}{l}\text { first-year under- } \\
\text { graduate/general; } \\
\text { chemical education } \\
\text { research; teaching } \\
\text { with technology; } \\
\text { computer-based } \\
\text { learning; laboratory } \\
\text { computing/inter- } \\
\text { facing }\end{array}$ & $\begin{array}{l}\text { Trabalho em } \\
\text { laboratório, } \\
\text { separação de } \\
\text { misturas }\end{array}$ & $\begin{array}{l}\text { Questionários: } \\
\text { quantitativo, } \\
\text { Relatórios }\end{array}$ & $\begin{array}{l}\text { Trabalho em } \\
\text { grupo, Trabalho } \\
\text { em laboratório }\end{array}$ & Interativo \\
\hline
\end{tabular}


Tabela 1S. Dados a partir dos quais se realizou o estudo (continuação)

\begin{tabular}{|c|c|c|c|c|c|c|c|c|c|}
\hline Ref. & Título & Autores & $\begin{array}{l}\text { País da } \\
\text { instituição } \\
\text { do } 1^{\circ} \text { autor }\end{array}$ & Tipo de artigo & Palavras-chave & $\begin{array}{l}\text { Conceitos } \\
\text { (até 2) }\end{array}$ & $\begin{array}{l}\text { Metodologia de } \\
\text { pesquisa (até 4) }\end{array}$ & $\begin{array}{c}\text { Metodologia } \\
\text { usada no contexto } \\
\text { educacional } \\
\text { (até 5) }\end{array}$ & $\begin{array}{l}\text { Meio } \\
\text { suporte } \\
\text { didático } 1 \\
\text { (até 3) }\end{array}$ \\
\hline $\begin{array}{l}\text { J. Chem. Educ. } \\
\text { 2003, } 80,109\end{array}$ & $\begin{array}{l}\text { Modeling A Boltzmann } \\
\text { Distribution: Simbo } \\
\text { (Simulated Boltzmann, } \\
\text { A Computer Laboratory } \\
\text { Exercise }\end{array}$ & $\begin{array}{l}\text { Lyubartsev A } \\
\text { P; Heald E F; } \\
\text { York R W }\end{array}$ & Suécia & $\begin{array}{l}\text { Recurso } \\
\text { didático }\end{array}$ & $\begin{array}{l}\text { upper-division } \\
\text { undergraduate; } \\
\text { physical chemistry; } \\
\text { JCE software; } \\
\text { computer-based } \\
\text { learning; laboratory } \\
\text { computing/inter- } \\
\text { facing }\end{array}$ & termodinâmica & Não citada & Não citada & Interativo \\
\hline $\begin{array}{l}\text { J. Chem. Educ. } \\
\text { 2003, } 80,157\end{array}$ & $\begin{array}{l}\text { Paper-And-Glue Unit } \\
\text { Cell Models }\end{array}$ & $\begin{array}{l}\text { Birk J P; } \\
\text { Yezierski E J; } \\
\text { Laing M }\end{array}$ & EUA & Metodologia & $\begin{array}{l}\text { high school/intro- } \\
\text { ductory chemistry; } \\
\text { demonstrations; } \\
\text { tested demonstra- } \\
\text { tions; solid state } \\
\text { chemistry }\end{array}$ & $\begin{array}{l}\text { estrutura } \\
\text { molecular }\end{array}$ & Não citada & $\begin{array}{l}\text { Trabalho em } \\
\text { grupo }\end{array}$ & $\begin{array}{l}\text { Modelos } \\
\text { físicos }\end{array}$ \\
\hline $\begin{array}{l}\text { J. Chem. Educ. } \\
\text { 2003, } 80,1425\end{array}$ & $\begin{array}{l}\text { Thermodynamics For } \\
\text { Visual Learners }\end{array}$ & Hamilton T M & EUA & $\begin{array}{l}\text { Recurso } \\
\text { didático }\end{array}$ & $\begin{array}{l}\text { upper-division } \\
\text { undergraduate; } \\
\text { physical chemistry; } \\
\text { thermodynamics }\end{array}$ & termodinâmica & Não citada & Não citada & $\begin{array}{l}\text { Ilustração } \\
\text { eletrônica }\end{array}$ \\
\hline $\begin{array}{l}\text { J. Chem. Educ. } \\
\text { 2004, } 81,1322\end{array}$ & $\begin{array}{l}\text { Teaching Ionic Solva- } \\
\text { tion Structure With A } \\
\text { Monte Carlo Liquid } \\
\text { Simulation Program }\end{array}$ & $\begin{array}{l}\text { Serrano A; } \\
\text { Santos F M T; } \\
\text { Greca I M }\end{array}$ & Brasil & Metodologia & $\begin{array}{l}\text { upper-division } \\
\text { undergraduate; } \\
\text { physical chemistry; } \\
\text { computer-based } \\
\text { learning; math- } \\
\text { ematics/symbolic } \\
\text { mathematics }\end{array}$ & $\begin{array}{l}\text { interações in- } \\
\text { termoleculares }\end{array}$ & Não citada & Não citada & Interativo \\
\hline $\begin{array}{l}\text { J. Chem. Educ. } \\
\text { 2004, } 81,587\end{array}$ & $\begin{array}{l}\text { The Effective Use Of } \\
\text { An Interactive Software } \\
\text { Program To Reduce } \\
\text { Students' Misconcep- } \\
\text { tions About Batteries }\end{array}$ & $\begin{array}{l}\text { Yang E M; } \\
\text { Greenbowe T } \\
\mathrm{J} ; \text { Andre T }\end{array}$ & EUA & Investigação & $\begin{array}{l}\text { high school/intro- } \\
\text { ductory chemistry; } \\
\text { chemical education } \\
\text { research; teaching } \\
\text { with technology; } \\
\text { computer-based } \\
\text { learning; electro- } \\
\text { chemistry }\end{array}$ & eletroquímica & $\begin{array}{l}\text { Questionários: } \\
\text { quantitativo, } \\
\text { Vídeo/Áudio }\end{array}$ & $\begin{array}{l}\text { Aula exposi- } \\
\text { tiva, Trabalho em } \\
\text { grupo }\end{array}$ & Interativo \\
\hline $\begin{array}{l}\text { J. Chem. Educ. } \\
\text { 2004, } 81,818\end{array}$ & $\begin{array}{l}\text { Visualizing Bent Bonds } \\
\text { In Cyclopropane }\end{array}$ & Bertolini T M & EUA & $\begin{array}{l}\text { Recurso } \\
\text { didático }\end{array}$ & $\begin{array}{l}\text { high school/intro- } \\
\text { ductory chemistry; } \\
\text { demonstrations; } \\
\text { overhOutros projec- } \\
\text { tor demonstrations; } \\
\text { molecular modeling }\end{array}$ & ligação química & Não citada & Não citada & $\begin{array}{l}\text { Modelos } \\
\text { físicos }\end{array}$ \\
\hline $\begin{array}{l}\text { J. Chem. Educ. } \\
\text { 2004, } 81,1136\end{array}$ & $\begin{array}{l}\text { Exploring Organic } \\
\text { Mechanistic Puzzles } \\
\text { With Molecular Model- } \\
\text { ing }\end{array}$ & $\begin{array}{l}\text { Horowitz G; } \\
\text { Schwartz G }\end{array}$ & EUA & Metodologia & $\begin{array}{l}\text { second-year under- } \\
\text { graduate; organic } \\
\text { chemistry; molecular } \\
\text { modeling exercises } \\
\text { and experiments; } \\
\text { collaborative/co- } \\
\text { operative learning; } \\
\text { molecular proper- } \\
\text { ties/structure }\end{array}$ & reações & Não citada & $\begin{array}{l}\text { Trabalho em } \\
\text { grupo }\end{array}$ & Interativo \\
\hline $\begin{array}{l}\text { J. Chem. Educ. } \\
\mathbf{2 0 0 4}, 81,1431\end{array}$ & $\begin{array}{l}\text { Introducing Mo- } \\
\text { lecular Visualization } \\
\text { To Primary Schools In } \\
\text { California: The Start! } \\
\text { Teaching Science } \\
\text { Through Art Program }\end{array}$ & Halpine S M & EUA & Metodologia & $\begin{array}{l}\text { elementary/middle } \\
\text { school science; } \\
\text { chemistry for kids; } \\
\text { computer-based } \\
\text { learning; bioinor- } \\
\text { ganic chemistry }\end{array}$ & $\begin{array}{l}\text { estrutura } \\
\text { molecular }\end{array}$ & $\begin{array}{l}\text { Desenho, } \\
\text { Questionários: } \\
\text { quantitativo }\end{array}$ & $\begin{array}{l}\text { Outros, Grupo de } \\
\text { discussão }\end{array}$ & $\begin{array}{c}\text { Interativo, } \\
\text { Modelos } \\
\text { físicos, Il- } \\
\text { ustração em } \\
\text { papel }\end{array}$ \\
\hline $\begin{array}{l}\text { J. Chem. Educ. } \\
\text { 2005, } 82,73\end{array}$ & $\begin{array}{l}\text { A Set Of Hands-On } \\
\text { Exercises On Confor- } \\
\text { mational Analysis }\end{array}$ & $\begin{array}{l}\text { Pellegrinet S } \\
\text { C; Mata E G }\end{array}$ & Argentina & Metodologia & $\begin{array}{l}\text { first-year under- } \\
\text { graduate/general; } \\
\text { organic chemistry; } \\
\text { collaborative/co- } \\
\text { operative learning; } \\
\text { alkanes/cycloalkanes }\end{array}$ & $\begin{array}{l}\text { análise confor- } \\
\text { macional }\end{array}$ & Não citada & $\begin{array}{l}\text { Trabalho em } \\
\text { grupo, Grupo de } \\
\text { discussão }\end{array}$ & $\begin{array}{l}\text { Modelos } \\
\text { físicos }\end{array}$ \\
\hline $\begin{array}{l}\text { J. Chem. Educ. } \\
\text { 2005, } 82,1800\end{array}$ & $\begin{array}{l}\text { A New Exploration Of } \\
\text { The Torsional Energy } \\
\text { Surface Of N-Pentane } \\
\text { Using Molecular } \\
\text { Models And Molecular } \\
\text { Modeling Software }\end{array}$ & $\begin{array}{c}\text { Galembeck S } \\
\text { E; Caramori } \\
\text { G F; Romero } \\
\text { J R }\end{array}$ & Brasil & Metodologia & $\begin{array}{l}\text { upper-division } \\
\text { undergraduate; } \\
\text { physical chemistry; } \\
\text { computer-based } \\
\text { learning; computa- } \\
\text { tional chemistry }\end{array}$ & $\begin{array}{l}\text { análise confor- } \\
\text { macional }\end{array}$ & Não citada & Não citada & $\begin{array}{l}\text { Interativo, } \\
\text { Modelos } \\
\text { físicos, }\end{array}$ \\
\hline $\begin{array}{l}\text { J. Chem. Educ. } \\
\mathbf{2 0 0 5}, 82,1805\end{array}$ & $\begin{array}{l}\text { Analyzing The 3D } \\
\text { Structure Of Human } \\
\text { Carbonic Anhydrase Ii } \\
\text { And Its Mutants Using } \\
\text { Deep View And The } \\
\text { Protein Data Bank }\end{array}$ & $\begin{array}{c}\text { Ship N J; } \\
\text { Zamble D B }\end{array}$ & Canadá & Metodologia & $\begin{array}{c}\text { upper-division } \\
\text { undergraduate; bio- } \\
\text { chemistry; molecular } \\
\text { modeling exercises } \\
\text { and experiments; } \\
\text { computer-based } \\
\text { learning; molecular } \\
\text { modeling }\end{array}$ & proteínas & $\begin{array}{l}\text { Seminários, } \\
\text { Relatórios }\end{array}$ & $\begin{array}{l}\text { Trabalho indi- } \\
\text { vidual }\end{array}$ & Interativo \\
\hline
\end{tabular}


Tabela 1S. Dados a partir dos quais se realizou o estudo (continuação)

\begin{tabular}{|c|c|c|c|c|c|c|c|c|c|}
\hline Ref. & Título & Autores & $\begin{array}{c}\text { País da } \\
\text { instituição } \\
\text { do } 1^{\circ} \text { autor }\end{array}$ & Tipo de artigo & Palavras-chave & $\begin{array}{l}\text { Conceitos } \\
\text { (até 2) }\end{array}$ & $\begin{array}{l}\text { Metodologia de } \\
\text { pesquisa (até 4) }\end{array}$ & $\begin{array}{c}\text { Metodologia } \\
\text { usada no contexto } \\
\text { educacional } \\
\text { (até 5) }\end{array}$ & $\begin{array}{c}\text { Meio } \\
\text { suporte } \\
\text { didático } 1 \\
\text { (até 3) }\end{array}$ \\
\hline $\begin{array}{l}\text { J. Chem. Educ. } \\
\mathbf{2 0 0 5}, 82,1741\end{array}$ & $\begin{array}{l}\text { Teaching Molecular } \\
\text { Symmetry With Jce } \\
\text { Webware }\end{array}$ & $\begin{array}{c}\text { Charistos N } \\
\text { D; Tsipis C A; } \\
\text { Sigalas M P }\end{array}$ & Grécia & $\begin{array}{l}\text { Recurso } \\
\text { didático }\end{array}$ & $\begin{array}{l}\text { first-year under- } \\
\text { graduate/general; } \\
\text { chemoinformatics; } \\
\text { JCE WebWare: web- } \\
\text { based learning aids; } \\
\text { computer-based } \\
\text { learning; group } \\
\text { theory/symmetry }\end{array}$ & simetria & Não citada & Não citada & Interativo \\
\hline $\begin{array}{l}\text { J. Chem. Educ. } \\
\mathbf{2 0 0 5}, 82,1021\end{array}$ & $\begin{array}{l}\text { Computer Modeling } \\
\text { And Research In The } \\
\text { Classroom }\end{array}$ & $\begin{array}{c}\text { Ramos M J; } \\
\text { Fernandes P A }\end{array}$ & Portugal & Metodologia & $\begin{array}{l}\text { upper-division } \\
\text { undergraduate; } \\
\text { computer-based } \\
\text { learning; computa- } \\
\text { tional chemistry }\end{array}$ & $\begin{array}{l}\text { estrutura } \\
\text { molecular }\end{array}$ & Relatório & $\begin{array}{c}\text { Aula exposi- } \\
\text { tiva, Trabalho em } \\
\text { grupo }\end{array}$ & Interativo \\
\hline $\begin{array}{l}\text { J. Chem. Educ. } \\
\mathbf{2 0 0 5}, 82,79\end{array}$ & $\begin{array}{l}\text { A 3D Model Of } \\
\text { Double-Helical Dna } \\
\text { Showing Variable } \\
\text { Chemical Details }\end{array}$ & Cady S G & EUA & $\begin{array}{l}\text { Recurso } \\
\text { didático }\end{array}$ & $\begin{array}{l}\text { high school/ } \\
\text { introductory chem- } \\
\text { istry; biochemistry; } \\
\text { hands-on learning/ } \\
\text { manipulatives; } \\
\text { biotechnology }\end{array}$ & $\begin{array}{l}\text { ácidos nuclei- } \\
\qquad \cos \end{array}$ & Não citada & Não citada & $\begin{array}{l}\text { Modelos } \\
\text { físicos }\end{array}$ \\
\hline $\begin{array}{l}\text { J. Chem. Educ. } \\
\mathbf{2 0 0 5}, 82,401\end{array}$ & $\begin{array}{l}\text { Simple Dynamic } \\
\text { Models For Hydrogen } \\
\text { Bonding Using Velcro- } \\
\text { Polarized Molecular } \\
\text { Models }\end{array}$ & Schultz E & EUA & $\begin{array}{l}\text { Recurso } \\
\text { didático }\end{array}$ & $\begin{array}{l}\text { high school/intro- } \\
\text { ductory chemistry; } \\
\text { demonstrations; } \\
\text { molecular proper- } \\
\text { ties/structure }\end{array}$ & $\begin{array}{l}\text { interações in- } \\
\text { termoleculares }\end{array}$ & Não citada & Não citada & $\begin{array}{l}\text { Modelos } \\
\text { físicos }\end{array}$ \\
\hline $\begin{array}{l}\text { J. Chem. Educ. } \\
\mathbf{2 0 0 5}, 82,937\end{array}$ & $\begin{array}{l}\text { Molecular Visualization } \\
\text { In Science Education: } \\
\text { An Evaluation Of } \\
\text { An Nsf-Sponsored } \\
\text { Workshop }\end{array}$ & $\begin{array}{l}\text { José T J; } \\
\text { Williamson } \\
\text { V M }\end{array}$ & EUA & Investigação & $\begin{array}{l}\text { first-year undergrad- } \\
\text { uate/general; cur- } \\
\text { riculum; chemical } \\
\text { education research; } \\
\text { conferences }\end{array}$ & Outros & $\begin{array}{l}\text { Likert, Pré/ } \\
\text { Pós-testes, } \\
\text { Questionários: } \\
\text { quantitativo }\end{array}$ & Outros & Outros \\
\hline $\begin{array}{l}\text { J. Chem. Educ. } \\
\text { 2005, } 82,1009\end{array}$ & $\begin{array}{l}\text { Chirality Made Simple: } \\
\text { A 1-And 2-Dimen- } \\
\text { sional Introduction To } \\
\text { Stereochemistry }\end{array}$ & Gawley R E & EUA & $\begin{array}{l}\text { Recurso } \\
\text { didático }\end{array}$ & $\begin{array}{c}\text { second-year } \\
\text { undergraduate; } \\
\text { organic chemistry; } \\
\text { analogies/transfer; } \\
\text { chirality/optical } \\
\text { activity } \\
\end{array}$ & simetria & Não citada & Não citada & $\begin{array}{l}\text { Modelos } \\
\text { físicos, Il- } \\
\text { ustração em } \\
\text { papel }\end{array}$ \\
\hline $\begin{array}{l}\text { J. Chem. Educ. } \\
\mathbf{2 0 0 5}, 82,1251\end{array}$ & $\begin{array}{l}\text { Assessing The Effect } \\
\text { Of Web-Based Learn- } \\
\text { ing Tools On Student } \\
\text { Understanding Of } \\
\text { Stoichiometry Using } \\
\text { Knowledge Space } \\
\text { Theory }\end{array}$ & $\begin{array}{c}\text { Arasasingham } \\
\text { R D; } \\
\text { Taagepera } \\
\text { M; Potter F; } \\
\text { Martorell I; } \\
\text { Lonjers S }\end{array}$ & EUA & Investigação & $\begin{array}{c}\text { first-year under- } \\
\text { graduate/general; } \\
\text { chemical education } \\
\text { research; teaching } \\
\text { with technology; } \\
\text { computer-based } \\
\text { learning; stoichi- } \\
\text { ometry }\end{array}$ & estequiometria & $\begin{array}{l}\text { Questionários: } \\
\text { quantitativo, } \\
\text { Likert }\end{array}$ & $\begin{array}{l}\text { Aula expositiva, } \\
\text { Grupo de dis- } \\
\text { cussão, Trabalho } \\
\text { individual }\end{array}$ & Interativo \\
\hline $\begin{array}{l}\text { J. Chem. Educ. } \\
\mathbf{2 0 0 5}, 82,1513\end{array}$ & $\begin{array}{l}\text { Techniques To Enhance } \\
\text { Instructors' Teaching } \\
\text { Effectiveness With } \\
\text { Chemistry Students } \\
\text { Who Are Blind Or } \\
\text { Visually Impaired }\end{array}$ & Supalo C & EUA & $\begin{array}{l}\text { Recurso } \\
\text { didático }\end{array}$ & $\begin{array}{l}\text { first-year under- } \\
\text { graduate/general; } \\
\text { laboratory instruc- } \\
\text { tion; testing/assess- } \\
\text { ment; enrichment/ } \\
\text { review materials } \\
\end{array}$ & Outros & Outros & Outros & Outros \\
\hline $\begin{array}{l}\text { J. Chem. Educ. } \\
\mathbf{2 0 0 5}, 82,1736\end{array}$ & $\begin{array}{l}\text { The Use Of The Free, } \\
\text { Open-Source Program } \\
\text { Jmol To Generate An } \\
\text { Interactive Web Site } \\
\text { To Teach Molecular } \\
\text { Symmetry }\end{array}$ & $\begin{array}{l}\text { Cass M E; } \\
\text { Rzepa H S; } \\
\text { Rzepa D } \\
\text { R;Williams } \\
\quad \text { C K }\end{array}$ & EUA & $\begin{array}{l}\text { Recurso } \\
\text { didático }\end{array}$ & $\begin{array}{l}\text { first-year under- } \\
\text { graduate/general; } \\
\text { physical chemistry; } \\
\text { internet/web-based } \\
\text { learning; group } \\
\text { theory/symmetry } \\
\end{array}$ & simetria & Não citada & Não citada & Interativo \\
\hline $\begin{array}{l}\text { J. Chem. Educ. } \\
\mathbf{2 0 0 6}, 83,1567\end{array}$ & $\begin{array}{l}\text { A Gel Permeation } \\
\text { Chromatography } \\
\text { Simulator From Jce } \\
\text { Webware }\end{array}$ & $\begin{array}{c}\text { Marson G A; } \\
\text { Torres B B }\end{array}$ & Brasil & Metodologia & $\begin{array}{c}\text { second-year } \\
\text { undergraduate/ } \\
\text { general second-year } \\
\text { undergraduate; } \\
\text { biochemistry; chro- } \\
\text { matography; com- } \\
\text { puter-based learning; } \\
\text { multimedia-based } \\
\text { learning }\end{array}$ & cromatografia & Não citada & $\begin{array}{l}\text { Trabalho em } \\
\text { grupo }\end{array}$ & Interativo \\
\hline $\begin{array}{l}\text { J. Chem. Educ. } \\
\mathbf{2 0 0 6}, 83,1353\end{array}$ & $\begin{array}{l}\text { Teaching Physical } \\
\text { Chemistry Experiments } \\
\text { With A Computer } \\
\text { Simulation By Labview }\end{array}$ & $\begin{array}{l}\text { Belletti A; } \\
\text { Borromei R; } \\
\text { Ingletto G }\end{array}$ & Itália & $\begin{array}{l}\text { Recurso } \\
\text { didático }\end{array}$ & $\begin{array}{l}\text { first-year under- } \\
\text { graduate/general; } \\
\text { physical chemistry; } \\
\text { computer-based } \\
\text { learning; equilibrium }\end{array}$ & equilíbrio & Não citada & $\begin{array}{l}\text { Trabalho em } \\
\text { laboratório }\end{array}$ & Interativo \\
\hline $\begin{array}{l}\text { J. Chem. Educ. } \\
\text { 2006, } 83,481\end{array}$ & $\begin{array}{l}\text { Computational } \\
\text { Quantum Chemistry: } \\
\text { A Reliable Tool In The } \\
\text { Understanding Of Gas- } \\
\text { Phase Reactions }\end{array}$ & $\begin{array}{c}\text { Galano A; } \\
\text { Alvarez- } \\
\text { Idaboy J R; } \\
\text { Vivier-Bunge } \\
\text { A }\end{array}$ & México & $\begin{array}{l}\text { Recurso } \\
\text { didático }\end{array}$ & $\begin{array}{l}\text { graduate education/ } \\
\text { research; physical } \\
\text { chemistry; research: } \\
\text { science and educa- } \\
\text { tion; computer-based } \\
\text { learning; applica- } \\
\text { tions of chemistry }\end{array}$ & reações & Não citada & Não citada & Interativo \\
\hline
\end{tabular}


Tabela 1S. Dados a partir dos quais se realizou o estudo (continuação)

\begin{tabular}{|c|c|c|c|c|c|c|c|c|c|}
\hline Ref. & Título & Autores & $\begin{array}{l}\text { País da } \\
\text { instituição } \\
\text { do } 1^{\circ} \text { autor }\end{array}$ & Tipo de artigo & Palavras-chave & $\begin{array}{l}\text { Conceitos } \\
\text { (até 2) }\end{array}$ & $\begin{array}{l}\text { Metodologia de } \\
\text { pesquisa (até 4) }\end{array}$ & $\begin{array}{c}\text { Metodologia } \\
\text { usada no contexto } \\
\text { educacional } \\
\text { (até 5) }\end{array}$ & $\begin{array}{c}\text { Meio } \\
\text { suporte } \\
\text { didático 1 } \\
\text { (até 3) }\end{array}$ \\
\hline $\begin{array}{l}\text { J. Chem. Educ. } \\
\text { 2006, } 83,170\end{array}$ & $\begin{array}{l}\text { Using Computer Simu- } \\
\text { lations To Teach Salt } \\
\text { Solubility }\end{array}$ & $\begin{array}{l}\text { Gil V M S; } \\
\text { Paiva J C M }\end{array}$ & Portugal & $\begin{array}{l}\text { Recurso } \\
\text { didático }\end{array}$ & $\begin{array}{l}\text { high school/intro- } \\
\text { ductory chemistry; } \\
\text { physical chemistry; } \\
\text { computational } \\
\text { chemistry } \\
\end{array}$ & termodinâmica & Não citada & Não citada & Interativo \\
\hline $\begin{array}{l}\text { J. Chem. Educ. } \\
\text { 2006, 83, } 1319\end{array}$ & $\begin{array}{l}\text { A Unique Demonstra- } \\
\text { tion Model Of Dna }\end{array}$ & Cox J P L & Reino Unido & $\begin{array}{l}\text { Recurso } \\
\text { didático }\end{array}$ & $\begin{array}{c}\text { elementary/middle } \\
\text { school science; bio- } \\
\text { chemistry; hands-on } \\
\text { learning/manipula- } \\
\text { tives; molecular } \\
\text { biology }\end{array}$ & $\begin{array}{l}\text { ácidos nuclei- } \\
\cos \end{array}$ & Não citada & Não citada & $\begin{array}{l}\text { Modelos } \\
\text { físicos }\end{array}$ \\
\hline $\begin{array}{l}\text { J. Chem. Educ. } \\
\text { 2006, } 83,77\end{array}$ & $\begin{array}{l}\text { Molecular Dynamics } \\
\text { Simulations Of Chemi- } \\
\text { cal Reactions For Use } \\
\text { In Education }\end{array}$ & $\begin{array}{c}\text { Xie Q; Tinker } \\
\text { R }\end{array}$ & EUA & $\begin{array}{l}\text { Recurso } \\
\text { didático }\end{array}$ & $\begin{array}{l}\text { upper-division } \\
\text { undergraduate; } \\
\text { chemical education } \\
\text { research; molecular } \\
\text { modeling exercises } \\
\text { and experiments; } \\
\text { computer-based } \\
\text { learning; molecular } \\
\text { mechanics/dynamics }\end{array}$ & cinética & Não citada & Não citada & Interativo \\
\hline $\begin{array}{l}\text { J. Chem. Educ. } \\
\text { 2006, } 83,336\end{array}$ & $\begin{array}{l}\text { Using Jmol To Help } \\
\text { Students Better } \\
\text { Understand Fluxional } \\
\text { Processes }\end{array}$ & $\begin{array}{l}\text { Cass M E; } \\
\text { Rzepa H S }\end{array}$ & EUA & $\begin{array}{l}\text { Recurso } \\
\text { didático }\end{array}$ & $\begin{array}{l}\text { first-year under- } \\
\text { graduate/general; } \\
\text { inorganic chemistry; } \\
\text { JCE WebWare: web- } \\
\text { based learning aids; } \\
\text { internet/web-based } \\
\text { learning; computa- } \\
\text { tional chemistry }\end{array}$ & reações & Não citada & Não citada & Interativo \\
\hline $\begin{array}{l}\text { J. Chem. Educ. } \\
\text { 2006, } 83,954\end{array}$ & $\begin{array}{l}\text { Misconceptions About } \\
\text { The Particulate Nature } \\
\text { Of Matter: Using } \\
\text { Animations To Close } \\
\text { The Gender Gap }\end{array}$ & $\begin{array}{l}\text { Yezierski E J; } \\
\text { Birk J P }\end{array}$ & EUA & Investigação & $\begin{array}{l}\text { elementary/middle } \\
\text { school science; } \\
\text { chemical education } \\
\text { research; construc- } \\
\text { tivism; learning } \\
\text { theories }\end{array}$ & $\begin{array}{l}\text { Natureza } \\
\text { particular da } \\
\text { matéria }\end{array}$ & $\begin{array}{l}\text { Pré/Pós-testes, } \\
\text { Entrevistas, } \\
\text { Vídeo/Áudio }\end{array}$ & $\begin{array}{l}\text { Grupo de dis- } \\
\text { cussão, Trabalho } \\
\text { individual, Aula } \\
\text { expositiva }\end{array}$ & Animação \\
\hline $\begin{array}{l}\text { J. Chem. Educ. } \\
\text { 2006, } 83,1182\end{array}$ & $\begin{array}{l}\text { A Laboratory Experi- } \\
\text { ment Using Molecular } \\
\text { Models For An Intro- } \\
\text { ductory Chemistry } \\
\text { Class }\end{array}$ & Ghaffari S & EUA & Metodologia & $\begin{array}{l}\text { high school/intro- } \\
\text { ductory chemistry; } \\
\text { demonstrations; } \\
\text { hands-on learning/ } \\
\text { manipulatives; mo- } \\
\text { lecular modeling } \\
\end{array}$ & vários & Não citada & $\begin{array}{l}\text { Trabalho em } \\
\text { grupo, Trabalho } \\
\text { em laboratório }\end{array}$ & $\begin{array}{l}\text { Modelos } \\
\text { físicos }\end{array}$ \\
\hline $\begin{array}{l}\text { J. Chem. Educ. } \\
\text { 2006, 83, } 1317\end{array}$ & $\begin{array}{l}\text { Classifying Matter: A } \\
\text { Physical Model Using } \\
\text { Paper Clips }\end{array}$ & $\begin{array}{c}\text { Blake B; } \\
\text { Hogue L; } \\
\text { Sarquis J L }\end{array}$ & EUA & $\begin{array}{l}\text { Recurso } \\
\text { didático }\end{array}$ & $\begin{array}{l}\text { elementary/middle } \\
\text { school science; cur- } \\
\text { riculum; analogies/ } \\
\text { transfer; molecular } \\
\text { properties/structure }\end{array}$ & $\begin{array}{l}\text { substâncias } \\
\text { simples e } \\
\text { compostas }\end{array}$ & Não citada & $\begin{array}{c}\text { Trabalho em } \\
\text { grupo }\end{array}$ & $\begin{array}{l}\text { Modelos } \\
\text { físicos }\end{array}$ \\
\hline $\begin{array}{l}\text { J. Chem. Educ. } \\
\text { 2006, } 83,1322\end{array}$ & $\begin{array}{l}\text { Using Physical Models } \\
\text { Of Biomolecular } \\
\text { Structures To Teach } \\
\text { Concepts Of Biochemi- } \\
\text { cal Structure And Struc- } \\
\text { ture Depiction In The } \\
\text { Introductory Chemistry } \\
\text { Laboratory }\end{array}$ & $\begin{array}{c}\text { Bain G } \\
\text { A; Yi J; } \\
\text { Beikmohamadi } \\
\text { M; Herman } \\
\text { T M; Patrick } \\
\text { M A }\end{array}$ & EUA & Metodologia & $\begin{array}{l}\text { high school/intro- } \\
\text { ductory chemistry; } \\
\text { biochemistry; hands- } \\
\text { on learning/manipu- } \\
\text { latives; amino acids }\end{array}$ & $\begin{array}{l}\text { ácidos nuclei- } \\
\text { cos, proteínas }\end{array}$ & Pré/Pós-testes & $\begin{array}{l}\text { Trabalho em } \\
\text { grupo, Aula } \\
\text { expositiva }\end{array}$ & $\begin{array}{l}\text { Modelos } \\
\text { físicos, In- } \\
\text { terativo }\end{array}$ \\
\hline $\begin{array}{l}\text { J. Chem. Educ. } \\
\text { 2007, 84, } 1866\end{array}$ & $\begin{array}{l}\text { Biochemical View: A } \\
\text { Web Site Providing } \\
\text { Material For Teaching } \\
\text { Biochemistry Using } \\
\text { Multiple Approaches }\end{array}$ & $\begin{array}{c}\text { Dórea F C; } \\
\text { Rodrigues H } \\
\text { S; Lapouble O } \\
\text { M M; Pereira } \\
\text { M R; Castro } \\
\text { M S; Fontes } \\
\text { W }\end{array}$ & Brasil & Investigação & $\begin{array}{l}\text { continuing educaton; } \\
\text { biochemistry; com- } \\
\text { puter-based learning; } \\
\text { amino acids }\end{array}$ & $\begin{array}{l}\text { vias metabóli- } \\
\text { cas }\end{array}$ & $\begin{array}{l}\text { Questionários: } \\
\text { quantitativo, } \\
\text { Likert }\end{array}$ & Aula expositiva & Interativo \\
\hline $\begin{array}{l}\text { J. Chem. Educ. } \\
\text { 2007, 84, } 979\end{array}$ & $\begin{array}{l}\text { Receptor Surface Mod- } \\
\text { els In The Classroom: } \\
\text { Introducing Molecular } \\
\text { Modeling To Students } \\
\text { In A 3-D World }\end{array}$ & $\begin{array}{l}\text { Geldenhuys W } \\
\text { J; Hayes M; } \\
\text { Van Der Schyf } \\
\text { C J; Allen D } \\
\text { D; Malan S F }\end{array}$ & EUA & Metodologia & $\begin{array}{l}\text { first-year under- } \\
\text { graduate/gen- } \\
\text { eral; biochemistry; } \\
\text { computer-based } \\
\text { learning; bioorganic } \\
\text { chemistry } \\
\end{array}$ & $\begin{array}{l}\text { interação } \\
\text { estérica }\end{array}$ & Likert & Não citada & $\begin{array}{l}\text { Interativo, } \\
\text { Modelos } \\
\text { físicos }\end{array}$ \\
\hline $\begin{array}{l}\text { J. Chem. Educ. } \\
\text { 2007, 84, } 1551\end{array}$ & $\begin{array}{l}\text { An Interactive Com- } \\
\text { puter Program To Help } \\
\text { Students Learn Molecu- } \\
\text { lar Symmetry Elements } \\
\text { And Operations }\end{array}$ & $\begin{array}{l}\text { Meyer D E; } \\
\text { Sargent A L }\end{array}$ & EUA & $\begin{array}{l}\text { Recurso } \\
\text { didático }\end{array}$ & $\begin{array}{l}\text { upper-division } \\
\text { undergraduate; } \\
\text { inorganic chemistry; } \\
\text { JCE WebWare: web- } \\
\text { based leraning aids; } \\
\text { computer-based } \\
\text { learning; group } \\
\text { theory symmetry }\end{array}$ & simetria & Não citada & Não citada & Interativo \\
\hline
\end{tabular}


Tabela 1S. Dados a partir dos quais se realizou o estudo (continuação)

\begin{tabular}{|c|c|c|c|c|c|c|c|c|c|}
\hline Ref. & Título & Autores & $\begin{array}{l}\text { País da } \\
\text { instituição } \\
\text { do } 1^{\circ} \text { autor }\end{array}$ & Tipo de artigo & Palavras-chave & $\begin{array}{l}\text { Conceitos } \\
\text { (até 2) }\end{array}$ & $\begin{array}{l}\text { Metodologia de } \\
\text { pesquisa (até 4) }\end{array}$ & $\begin{array}{c}\text { Metodologia } \\
\text { usada no contexto } \\
\text { educacional } \\
\text { (até 5) }\end{array}$ & $\begin{array}{c}\text { Meio } \\
\text { suporte } \\
\text { didático } 1 \\
\text { (até 3) }\end{array}$ \\
\hline $\begin{array}{l}\text { J. Chem. Educ. } \\
\text { 2007, 84, } 1776\end{array}$ & $\begin{array}{l}\text { Visualizing The Transi- } \\
\text { tion State:A Hands-On } \\
\text { Approach To The } \\
\text { Arrhenius Equation }\end{array}$ & $\begin{array}{c}\text { Kuntzleman } \\
\text { T S; Swanson } \\
\text { M S; Sayers } \\
\text { D K }\end{array}$ & EUA & Metodologia & $\begin{array}{l}\text { first-year under- } \\
\text { graduate/general; } \\
\text { laboratory instruc- } \\
\text { tion; applications } \\
\text { and analogies; } \\
\text { analogies/transfer; } \\
\text { kinetics } \\
\end{array}$ & cinética & Não citada & $\begin{array}{l}\text { Trabalho em } \\
\text { grupo }\end{array}$ & Outros \\
\hline $\begin{array}{l}\text { J. Chem. Educ. } \\
\text { 2007, 84, } 1945\end{array}$ & $\begin{array}{l}\text { Predicting The Shifts } \\
\text { Of Absorption Maxima } \\
\text { Of Azulene Deriva- } \\
\text { tives Using Molecular } \\
\text { Modeling And Zindo Ci } \\
\text { Calculations Of Uv-Vis } \\
\text { Spectra }\end{array}$ & $\begin{array}{l}\text { Patalinghug W } \\
\text { C; Chang M; } \\
\text { Solis J }\end{array}$ & EUA & $\begin{array}{l}\text { Recurso } \\
\text { didático }\end{array}$ & $\begin{array}{l}\text { upper-division } \\
\text { undergraduate; labo- } \\
\text { ratory instruction; } \\
\text { molecular modeling } \\
\text { exercises and experi- } \\
\text { ments; analogies/ } \\
\text { transfers; aromatic } \\
\text { compounds }\end{array}$ & espectroscopia & Não citada & Não citada & Interativo \\
\hline $\begin{array}{l}\text { J. Chem. Educ. } \\
\mathbf{2 0 0 8}, 85,444\end{array}$ & $\begin{array}{l}\text { Constructing Ih Sym- } \\
\text { metrical Fullerenes } \\
\text { From Pentagons }\end{array}$ & Gan L H & China & $\begin{array}{l}\text { Recurso } \\
\text { didático }\end{array}$ & $\begin{array}{l}\text { upper-division } \\
\text { undergraduate; } \\
\text { physical chemistry; } \\
\text { computer-based } \\
\text { learning; carbon }\end{array}$ & simetria & Não citada & Não citada & Interativo \\
\hline $\begin{array}{l}\text { J. Chem. Educ. } \\
\mathbf{2 0 0 8}, 85,240\end{array}$ & $\begin{array}{l}\text { Using Tactile Learning } \\
\text { Aids For Students With } \\
\text { Visual Impairments } \\
\text { In A First-Semester } \\
\text { Organic Chemistry } \\
\text { Course }\end{array}$ & $\begin{array}{c}\text { Poon T; } \\
\text { Ovadia R }\end{array}$ & EUA & Metodologia & $\begin{array}{l}\text { second-year under- } \\
\text { graduate; organic } \\
\text { chemistry; hands-on } \\
\text { learning/manipula- } \\
\text { tives; molecular } \\
\text { modeling }\end{array}$ & vários & $\begin{array}{l}\text { Desenho, } \\
\text { Questionários: } \\
\text { qualitativo }\end{array}$ & $\begin{array}{l}\text { Trabalho indi- } \\
\text { vidual }\end{array}$ & $\begin{array}{l}\text { Modelos } \\
\text { físicos }\end{array}$ \\
\hline $\begin{array}{l}\text { J. Chem. Educ. } \\
\mathbf{2 0 0 8}, 85,303\end{array}$ & $\begin{array}{l}\text { Investigating Students' } \\
\text { Ability To Transfer } \\
\text { Ideas Learned From } \\
\text { Molecular Animations } \\
\text { Of The Dissolution } \\
\text { Process }\end{array}$ & $\begin{array}{l}\text { Kelly R M; } \\
\text { Jones L L }\end{array}$ & EUA & Investigação & $\begin{array}{l}\text { first-year under- } \\
\text { graduate/general; } \\
\text { chemical education } \\
\text { research; computer- } \\
\text { based learning; } \\
\text { aqueous solution } \\
\text { chemistry }\end{array}$ & reações & $\begin{array}{l}\text { Desenho, Ent- } \\
\text { revistas, Vídeo/ } \\
\text { Áudio }\end{array}$ & $\begin{array}{l}\text { Trabalho indi- } \\
\text { vidual }\end{array}$ & Animação \\
\hline $\begin{array}{l}\text { J. Chem. Educ. } \\
\mathbf{2 0 0 8}, 85,718\end{array}$ & $\begin{array}{l}\text { The Effects Of A Two- } \\
\text { Year Molecular Visu- } \\
\text { alization Experience } \\
\text { On Teachers' Attitudes, } \\
\text { Content Knowledge, } \\
\text { And Spatial Ability }\end{array}$ & $\begin{array}{l}\text { Willianson V } \\
\text { M; José T J }\end{array}$ & EUA & Investigação & $\begin{array}{l}\text { first-year under- } \\
\text { graduate/general; } \\
\text { chemical education } \\
\text { research; construc- } \\
\text { tivism; molecular } \\
\text { modeling } \\
\end{array}$ & $\begin{array}{l}\text { Não espe- } \\
\text { cificado }\end{array}$ & $\begin{array}{l}\text { Likert, Pré/Pós- } \\
\text { testes }\end{array}$ & $\begin{array}{l}\text { Trabalho em } \\
\text { grupo, Outros }\end{array}$ & $\begin{array}{l}\text { Interativo, } \\
\text { Animação }\end{array}$ \\
\hline $\begin{array}{l}\text { J. Chem. Educ. } \\
\mathbf{2 0 0 8}, 85,822\end{array}$ & $\begin{array}{l}\text { Exploring Solid-State } \\
\text { Structure And Physical } \\
\text { Properties: A Molecular } \\
\text { And Crystal Model } \\
\text { Exercise }\end{array}$ & Bindel T H & EUA & Metodologia & $\begin{array}{l}\text { first-year under- } \\
\text { graduate/general; } \\
\text { inorganic chemistry; } \\
\text { hands-on learning/ } \\
\text { manipulatives; crys- } \\
\text { tals/crystallography } \\
\end{array}$ & simetria & Não citada & $\begin{array}{l}\text { Trabalho em } \\
\text { grupo, Trabalho } \\
\text { em laboratório }\end{array}$ & $\begin{array}{l}\text { Modelos } \\
\text { físicos }\end{array}$ \\
\hline $\begin{array}{l}\text { J. Chem. Educ. } \\
\mathbf{2 0 0 8}, 85,1071\end{array}$ & $\begin{array}{l}\text { Using Molecular } \\
\text { Dynamics Simulation } \\
\text { To Reinforce Student } \\
\text { Understanding Of Inter- } \\
\text { molecular Forces }\end{array}$ & $\begin{array}{l}\text { Burkholder P } \\
\text { R;Purser G H; } \\
\text { Cole R S }\end{array}$ & EUA & Metodologia & $\begin{array}{l}\text { first-year undergrad- } \\
\text { uate/general; cur- } \\
\text { riculum; molecular } \\
\text { modeling exercises } \\
\text { and experiments; } \\
\text { computer-based } \\
\text { learning; computa- } \\
\text { tional chemistry }\end{array}$ & $\begin{array}{l}\text { interações in- } \\
\text { termoleculares }\end{array}$ & Não citada & Não citada & Interativo \\
\hline $\begin{array}{l}\text { J. Chem. Educ. } \\
\mathbf{2 0 0 9}, 86,477\end{array}$ & $\begin{array}{l}\text { Conformational Analy- } \\
\text { sis Of Drug Molecules: } \\
\text { A Practical Exercise In } \\
\text { The Medicinal Chemis- } \\
\text { try Course }\end{array}$ & $\begin{array}{l}\text { Yuriev E; } \\
\text { Chalmers D; } \\
\text { Capuano D }\end{array}$ & Austrália & $\begin{array}{l}\text { Recurso } \\
\text { didático }\end{array}$ & $\begin{array}{l}\text { second-year } \\
\text { undergraduate; bio- } \\
\text { chemistry; molecular } \\
\text { modeling exercises } \\
\text { and experiments; } \\
\text { computer-based } \\
\text { learning; computa- } \\
\text { tional chemistry }\end{array}$ & $\begin{array}{l}\text { análise confor- } \\
\text { macional }\end{array}$ & Não citada & Não citada & Interativo \\
\hline $\begin{array}{l}\text { J. Chem. Educ. } \\
\text { 2009, } 86,19\end{array}$ & $\begin{array}{l}\text { Board-Game Gel } \\
\text { Filtration And Affinity } \\
\text { Chromatography }\end{array}$ & $\begin{array}{c}\text { Hunt E A; Deo } \\
\text { S K }\end{array}$ & EUA & $\begin{array}{l}\text { Recurso } \\
\text { didático }\end{array}$ & $\begin{array}{l}\text { first-year under- } \\
\text { graduate/general; } \\
\text { analytical chemistry; } \\
\text { classroom activity } \\
\text { connections; collab- } \\
\text { orative/cooperative } \\
\text { learning; bioanalyti- } \\
\text { cal chemistry }\end{array}$ & cromatografia & Não citada & Não citada & $\begin{array}{l}\text { Ilustração } \\
\text { em papel }\end{array}$ \\
\hline $\begin{array}{l}\text { J. Chem. Educ. } \\
\text { 2009, } 86,254\end{array}$ & $\begin{array}{l}\text { Visualization Tools For } \\
\text { Organic Chemistry }\end{array}$ & Musyka J L & EUA & $\begin{array}{l}\text { Recurso } \\
\text { didático }\end{array}$ & $\begin{array}{l}\text { second-year under- } \\
\text { graduate; organic } \\
\text { chemistry; JCE: } \\
\text { WebWare: web- } \\
\text { based learning aids; } \\
\text { Internet/web-based } \\
\text { learning; alkanes/ } \\
\text { cycloalkanes }\end{array}$ & vários & Não citada & Não citada & Interativo \\
\hline
\end{tabular}


Tabela 1S. Dados a partir dos quais se realizou o estudo (continuação)

\begin{tabular}{|c|c|c|c|c|c|c|c|c|c|}
\hline Ref. & Título & Autores & $\begin{array}{l}\text { País da } \\
\text { instituição } \\
\text { do } 1^{\circ} \text { autor }\end{array}$ & Tipo de artigo & Palavras-chave & $\begin{array}{l}\text { Conceitos } \\
\text { (até 2) }\end{array}$ & $\begin{array}{l}\text { Metodologia de } \\
\text { pesquisa (até 4) }\end{array}$ & $\begin{array}{c}\text { Metodologia } \\
\text { usada no contexto } \\
\text { educacional } \\
\text { (até 5) }\end{array}$ & $\begin{array}{c}\text { Meio } \\
\text { suporte } \\
\text { didático } 1 \\
\text { (até 3) }\end{array}$ \\
\hline $\begin{array}{l}\text { J. Chem. Educ. } \\
\mathbf{2 0 0 9}, 86,450\end{array}$ & $\begin{array}{l}\text { Enthalpy Costs Of } \\
\text { Making And Breaking } \\
\text { Bonds: A Game Of } \\
\text { Generating Molecules } \\
\text { With Proper Lewis } \\
\text { Structures }\end{array}$ & $\begin{array}{l}\text { Bell P T; } \\
\text { Adkins A D; } \\
\text { Gamble R J; } \\
\text { Schultz L D }\end{array}$ & EUA & $\begin{array}{l}\text { Recurso } \\
\text { didático }\end{array}$ & $\begin{array}{l}\text { first-year under- } \\
\text { graduate/general; } \\
\text { organic chemistry; } \\
\text { humor/puzzles/ } \\
\text { game; calorimetry/ } \\
\text { thermochemistry }\end{array}$ & ligação química & $\begin{array}{l}\text { Questionários: } \\
\text { quantitativo }\end{array}$ & $\begin{array}{l}\text { Trabalho em } \\
\text { grupo }\end{array}$ & $\begin{array}{l}\text { Ilustração } \\
\text { em papel }\end{array}$ \\
\hline $\begin{array}{l}\text { J. Chem. Educ. } \\
\text { 2009, } 86,460\end{array}$ & $\begin{array}{l}\text { Using The Cambridge } \\
\text { Structural Database } \\
\text { To Teach Molecular } \\
\text { Geometry Concepts In } \\
\text { Organic Chemistry }\end{array}$ & $\begin{array}{l}\text { Wackerly J W; } \\
\text { Janowicz P A; } \\
\text { Ritchey J A; } \\
\text { Caruso M M; } \\
\text { Elliott E L; } \\
\text { Moore J S }\end{array}$ & EUA & Metodologia & $\begin{array}{l}\text { second-year under- } \\
\text { graduate; organic } \\
\text { chemistry; teaching } \\
\text { with technology; } \\
\text { computer-based } \\
\text { learning; atomic } \\
\text { properties/structure }\end{array}$ & $\begin{array}{l}\text { estrutura } \\
\text { molecular }\end{array}$ & $\begin{array}{l}\text { Likert, Pré/Pós- } \\
\text { testes }\end{array}$ & $\begin{array}{l}\text { Trabalho indi- } \\
\text { vidual }\end{array}$ & Interativo \\
\hline $\begin{array}{l}\text { J. Chem. Educ. } \\
\mathbf{2 0 0 9}, 86,1442\end{array}$ & $\begin{array}{l}\text { Kinetic Versus Static } \\
\text { Visuals For Facilitating } \\
\text { College Students' Un- } \\
\text { derstanding Of Organic } \\
\text { Reaction Mechanisms } \\
\text { In Chemistry }\end{array}$ & $\begin{array}{c}\text { Aldahmash A } \\
\text { H; Abraham } \\
\text { M R }\end{array}$ & Yemen & Investigação & $\begin{array}{l}\text { second-year under- } \\
\text { graduate; chemical } \\
\text { education research; } \\
\text { reaearch: science } \\
\text { and education; } \\
\text { multimedia-based } \\
\text { learning; learning } \\
\text { theories }\end{array}$ & reações & $\begin{array}{l}\text { Pré/Pós-testes, } \\
\text { Questionários: } \\
\text { quantitativo, } \\
\text { Desenho }\end{array}$ & $\begin{array}{l}\text { Aula expositiva, } \\
\text { Trabalho indi- } \\
\text { vidual }\end{array}$ & $\begin{array}{l}\text { Animação, } \\
\text { Ilustração } \\
\text { eletrônica }\end{array}$ \\
\hline $\begin{array}{l}\text { J. Chem. Educ. } \\
\text { 2010, } 87,406\end{array}$ & $\begin{array}{l}\text { Where'S Ester? A } \\
\text { Game That Seeks The } \\
\text { Structures Hiding } \\
\text { Behind The Trivial } \\
\text { Names }\end{array}$ & $\begin{array}{l}\text { Angelin M; } \\
\text { Ramström O }\end{array}$ & Suécia & $\begin{array}{l}\text { Recurso } \\
\text { didático }\end{array}$ & $\begin{array}{l}\text { first-year under- } \\
\text { graduate/general; } \\
\text { general public; high } \\
\text { school/introductory } \\
\text { chemistry; second- } \\
\text { year undergraduate; } \\
\text { upper-division } \\
\text { undergraduate; bio- } \\
\text { chemistry; organic } \\
\text { chemistry; humor/ } \\
\text { puzzles/games; } \\
\text { amino acids; drugs/ } \\
\text { pharmaceuticals; } \\
\text { nomenclature/units/ } \\
\text { symbols }\end{array}$ & nomenclatura & Não citada & $\begin{array}{l}\text { Trabalho em } \\
\text { grupo }\end{array}$ & $\begin{array}{l}\text { Ilustração } \\
\text { em papel }\end{array}$ \\
\hline $\begin{array}{l}\text { J. Chem. Educ. } \\
\text { 2010, } 87,809\end{array}$ & $\begin{array}{l}\text { Teaching Three- } \\
\text { Dimensional } \\
\text { Structural Chemistry } \\
\text { Using Crystal Structure } \\
\text { Databases. } 1 \text {. An Inter- } \\
\text { active Web-Accessible } \\
\text { Teaching Subset Of The } \\
\text { Cambridge Structural } \\
\text { Database }\end{array}$ & $\begin{array}{c}\text { Battle G M; } \\
\text { Allen F H; } \\
\text { Ferrence G M }\end{array}$ & Reino Unido & $\begin{array}{l}\text { Recurso } \\
\text { didático }\end{array}$ & $\begin{array}{l}\text { second-year under- } \\
\text { graduate; upper-divi- } \\
\text { sion undergraduate; } \\
\text { chemoinformatics; } \\
\text { internet/web-based } \\
\text { learning }\end{array}$ & $\begin{array}{l}\text { estrutura } \\
\text { molecular }\end{array}$ & Não citada & Não citada & Interativo \\
\hline $\begin{array}{l}\text { J. Chem. Educ. } \\
\mathbf{2 0 1 0}, 87,819\end{array}$ & $\begin{array}{l}\text { A Pictorial Visual- } \\
\text { ization Of Normal } \\
\text { Mode Vibrations Of } \\
\text { The Fullerene (C60 } \\
\text { Molecule In Terms Of } \\
\text { Vibrations Of A Hollow } \\
\text { Sphere }\end{array}$ & Dunn J L & Reino Unido & $\begin{array}{l}\text { Recurso } \\
\text { didático }\end{array}$ & $\begin{array}{l}\text { upper-division } \\
\text { undergraduate; } \\
\text { graduate education/ } \\
\text { research; chemoin- } \\
\text { formatics; computer- } \\
\text { based learning; } \\
\text { group theory/ } \\
\text { symmetry; theorical } \\
\text { chemistry }\end{array}$ & simetria & Não citada & Não citada & Interativo \\
\hline $\begin{array}{l}\text { J. Chem. Educ. } \\
\text { 2010, } 87,291\end{array}$ & $\begin{array}{l}\text { Use Of Molecular Mod- } \\
\text { els For Active Learning } \\
\text { In Biochemistry } \\
\text { Lecture Courses }\end{array}$ & Hageman J H & EUA & $\begin{array}{l}\text { Recurso } \\
\text { didático }\end{array}$ & $\begin{array}{l}\text { upper-division } \\
\text { undergraduate; } \\
\text { biochemistry; } \\
\text { organic chemistry; } \\
\text { analogies/transfer; } \\
\text { collaborative/co- } \\
\text { operative learning; } \\
\text { hands-on learning/ } \\
\text { manipulatives }\end{array}$ & $\begin{array}{l}\text { estrutura } \\
\text { molecular }\end{array}$ & Não citada & $\begin{array}{l}\text { Trabalho em } \\
\text { grupo, Grupo de } \\
\text { discussão }\end{array}$ & $\begin{array}{l}\text { Modelos } \\
\text { físicos }\end{array}$ \\
\hline $\begin{array}{l}\text { J. Chem. Educ. } \\
\text { 2010, 87, } 294\end{array}$ & $\begin{array}{l}\text { A Hands-On Classroom } \\
\text { Simulation To Dem- } \\
\text { onstrate Concepts In } \\
\text { Enzyme Kinetics }\end{array}$ & Junker M & EUA & Metodologia & $\begin{array}{l}\text { second-year under- } \\
\text { graduate; upper- } \\
\text { division undergradu- } \\
\text { ate; biochemistry; } \\
\text { analogies/transfer; } \\
\text { hands-on learning/ } \\
\text { manipulatives; } \\
\text { catalysis; enzymes; } \\
\text { kinetics; mechanism } \\
\text { of reactions }\end{array}$ & cinética & Não citada & $\begin{array}{l}\text { Trabalho em } \\
\text { grupo, Grupo de } \\
\text { discussão }\end{array}$ & Outros \\
\hline
\end{tabular}


Tabela 1S. Dados a partir dos quais se realizou o estudo (continuação)

\begin{tabular}{|c|c|c|c|c|c|c|c|c|c|}
\hline Ref. & Título & Autores & $\begin{array}{c}\text { País da } \\
\text { instituição } \\
\text { do } 1^{\circ} \text { autor }\end{array}$ & Tipo de artigo & Palavras-chave & $\begin{array}{l}\text { Conceitos } \\
\text { (até 2) }\end{array}$ & $\begin{array}{l}\text { Metodologia de } \\
\text { pesquisa (até 4) }\end{array}$ & $\begin{array}{c}\text { Metodologia } \\
\text { usada no contexto } \\
\text { educacional } \\
\text { (até 5) }\end{array}$ & $\begin{array}{c}\text { Meio } \\
\text { suporte } \\
\text { didático } 1 \\
\text { (até 3) }\end{array}$ \\
\hline $\begin{array}{l}\text { J. Chem. Educ. } \\
\mathbf{2 0 1 0}, 87,827\end{array}$ & $\begin{array}{l}\text { Dynamic Paper } \\
\text { Constructions For } \\
\text { Easier Visualization Of } \\
\text { Molecular Symmetry }\end{array}$ & Sein Jr L T & EUA & $\begin{array}{l}\text { Recurso } \\
\text { didático }\end{array}$ & $\begin{array}{l}\text { upper-division } \\
\text { undergraduate; inor- } \\
\text { ganic chemistry; lab- } \\
\text { oratory instruction; } \\
\text { physical chemistry; } \\
\text { hands-on learning/ } \\
\text { manipulatives; group } \\
\text { theory/symmetry; } \\
\text { molecular proper- } \\
\text { ties/structure }\end{array}$ & simetria & Não citada & Não citada & $\begin{array}{l}\text { Modelos } \\
\text { físicos }\end{array}$ \\
\hline $\begin{array}{l}\text { J. Chem. Educ. } \\
\mathbf{2 0 1 0}, 87,924\end{array}$ & $\begin{array}{l}\text { Articulate Pictures } \\
\text { And Kinetic-Molecular } \\
\text { Theory Concepts: Seiz- } \\
\text { ing An Opportunity }\end{array}$ & Waner M J & EUA & $\begin{array}{l}\text { Recurso } \\
\text { didático }\end{array}$ & $\begin{array}{l}\text { elementary/middle } \\
\text { school science; high } \\
\text { school/introductory } \\
\text { chemistry; first-year } \\
\text { undergraduate/gen- } \\
\text { eral; upper-division } \\
\text { undergraduate; } \\
\text { physical chemistry; } \\
\text { chemical education } \\
\text { research; gases; } \\
\text { kinetic-molecular } \\
\text { theory }\end{array}$ & $\begin{array}{l}\text { Natureza partic- } \\
\text { ular da matéria, } \\
\text { cinética }\end{array}$ & Não citada & Não citada & $\begin{array}{l}\text { Ilustração } \\
\text { em papel }\end{array}$ \\
\hline $\begin{array}{l}\text { J. Chem. Educ. } \\
\mathbf{2 0 1 0}, 87,1024\end{array}$ & $\begin{array}{l}\text { Fusion Science Theater } \\
\text { Presents The Amazing } \\
\text { Chemical Circus: A } \\
\text { New Model Of Out- } \\
\text { reach That Uses Theater } \\
\text { To Engage Children In } \\
\text { Learning }\end{array}$ & $\begin{array}{l}\text { Kerby H W; } \\
\text { Cantor J; } \\
\text { Weiland M; } \\
\text { Barbiarz C; } \\
\text { Kerby A W }\end{array}$ & EUA & Metodologia & $\begin{array}{l}\text { first-year under- } \\
\text { graduate/gen- } \\
\text { eral; general public; } \\
\text { elementary/middle } \\
\text { school science; } \\
\text { interdisciplinary/ } \\
\text { multidisciplinary; } \\
\text { demonstrations; } \\
\text { public understand- } \\
\text { ing/outreach; testing/ } \\
\text { assessment; inquiry- } \\
\text { based/discovery } \\
\text { learning; applica- } \\
\text { tions of chemistry; } \\
\text { student-centered } \\
\text { learning }\end{array}$ & vários & $\begin{array}{l}\text { Likert, Pré/Pós- } \\
\text { testes, Desenho }\end{array}$ & Outros & Outros \\
\hline $\begin{array}{l}\text { J. Res. Sci. Teach. } \\
\text { 2001, } 38,821\end{array}$ & $\begin{array}{l}\text { Promoting Understand- } \\
\text { ing Of Chemical Rep- } \\
\text { resentations: Students' } \\
\text { Use Of A Visualization } \\
\text { Tool In The Classroom }\end{array}$ & $\begin{array}{l}\text { Wu H K; } \\
\text { Krajcik J S; } \\
\text { Soloway E }\end{array}$ & EUA & Metodologia & Não citadas & vários & $\begin{array}{l}\text { Pré/Pós Testes, } \\
\text { Entrevistas, } \\
\text { Vídeo/Áudio }\end{array}$ & $\begin{array}{c}\text { Aula exposi- } \\
\text { tiva, Trabalho em } \\
\text { grupo, Grupo de } \\
\text { discussão }\end{array}$ & $\begin{array}{l}\text { Interativo, } \\
\text { Modelos } \\
\text { físicos, Il- } \\
\text { ustração } \\
\text { eletrônica } \\
\end{array}$ \\
\hline $\begin{array}{l}\text { J. Res. Sci. Teach. } \\
\mathbf{2 0 0 4}, 41,317\end{array}$ & $\begin{array}{l}\text { Effectiveness Of } \\
\text { Multimedia-Based } \\
\text { Instruction That } \\
\text { Emphasizes Molecular } \\
\text { Representations On } \\
\text { Students' Understand- } \\
\text { ing Of Chemical } \\
\text { Change }\end{array}$ & $\begin{array}{c}\text { Ardac C; } \\
\text { Akaygun S }\end{array}$ & Turquia & Investigação & Não citadas & $\begin{array}{c}\text { reações, } \\
\text { Natureza } \\
\text { particular da } \\
\text { matéria }\end{array}$ & $\begin{array}{l}\text { Pré/Pós-testes, } \\
\text { Entrevistas, } \\
\text { Desenho }\end{array}$ & $\begin{array}{l}\text { Aula expositiva, } \\
\text { Trabalho em lab- } \\
\text { oratório, Trabalho } \\
\text { individual }\end{array}$ & Interativo \\
\hline $\begin{array}{l}\text { J. Res. Sci. Teach. } \\
\mathbf{2 0 0 6}, 43,500\end{array}$ & $\begin{array}{l}\text { Effect Of Bead And } \\
\text { Illustrations Models On } \\
\text { High School Students' } \\
\text { Achievement In Mo- } \\
\text { lecular Genetics }\end{array}$ & $\begin{array}{l}\text { Rotbain Y; } \\
\text { Marbach-Ad } \\
\text { G; Stavy R }\end{array}$ & Israel & Investigação & Não citadas & $\begin{array}{l}\text { ácidos nuclei- } \\
\cos \end{array}$ & $\begin{array}{l}\text { Pré/Pós-testes, } \\
\text { Questionários: } \\
\text { quantitativo, } \\
\text { Entrevistas }\end{array}$ & $\begin{array}{l}\text { Aula expositiva, } \\
\text { Trabalho indi- } \\
\text { vidual, Trabalho } \\
\text { em grupo, Grupo } \\
\text { de discussão }\end{array}$ & $\begin{array}{l}\text { Modelos } \\
\text { físicos, Il- } \\
\text { ustração em } \\
\text { papel }\end{array}$ \\
\hline $\begin{array}{l}\text { J. Res. Sci. Teach. } \\
\mathbf{2 0 0 8}, 45,219\end{array}$ & $\begin{array}{l}\text { Chemical Understand- } \\
\text { ing And Graphing } \\
\text { Skills In An Honors } \\
\text { Case-Based Computer- } \\
\text { ized Chemistry Labora- } \\
\text { tory Environment: The } \\
\text { Value Of Bidirectional } \\
\text { Visual And Textual } \\
\text { Representations }\end{array}$ & $\begin{array}{l}\text { Dori Y J; } \\
\text { Sasson I }\end{array}$ & Israel & Investigação & $\begin{array}{l}\text { chemistry; laboratory } \\
\text { science; secondary; } \\
\text { achievement; } \\
\text { classroom research }\end{array}$ & vários & $\begin{array}{l}\text { Question- } \\
\text { ários: qualitativo, } \\
\text { Questionários: } \\
\text { quantitativo }\end{array}$ & $\begin{array}{c}\text { Outros, Aula ex- } \\
\text { positiva, Trabalho } \\
\text { em laboratório, } \\
\text { Grupo de dis- } \\
\text { cussão, Trabalho } \\
\text { individual }\end{array}$ & $\begin{array}{l}\text { Interativo, } \\
\text { Ilustração } \\
\text { eletrônica }\end{array}$ \\
\hline 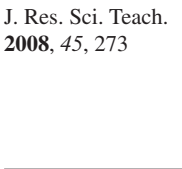 & $\begin{array}{l}\text { Using Computer Ani- } \\
\text { mation And Illustration } \\
\text { Activities To Improve } \\
\text { High School Students' } \\
\text { Achievement In Mo- } \\
\text { lecular Genetics }\end{array}$ & $\begin{array}{l}\text { Marbach-Ad } \\
\text { G; Rotbain Y; } \\
\text { Stavy R }\end{array}$ & Israel & Investigação & $\begin{array}{l}\text { biology; achieve- } \\
\text { ment; attitudes }\end{array}$ & $\begin{array}{l}\text { ácidos nuclei- } \\
\cos \end{array}$ & $\begin{array}{l}\text { Pré/Pós-testes, } \\
\text { Questionários: } \\
\text { quantitativo, } \\
\text { Entrevistas }\end{array}$ & $\begin{array}{l}\text { Aula expositiva, } \\
\text { Trabalho indi- } \\
\text { vidual, Grupo de } \\
\text { discussão }\end{array}$ & $\begin{array}{l}\text { Interativo, } \\
\text { Ilustração } \\
\text { em papel }\end{array}$ \\
\hline $\begin{array}{l}\text { J. Res. Sci. Teach. } \\
\mathbf{2 0 0 9}, 46,289\end{array}$ & $\begin{array}{l}\text { Enhancing Students' } \\
\text { Understanding Of The } \\
\text { Concept Of Chemical } \\
\text { Bonding By Using Ac- } \\
\text { tivities Provided On An } \\
\text { Interactive Website }\end{array}$ & $\begin{array}{l}\text { Frailich M; } \\
\text { Kesner M; } \\
\text { Hofstein A }\end{array}$ & Israel & Investigação & $\begin{array}{l}\text { chemistry; technol- } \\
\text { ogy education/ } \\
\text { software design; } \\
\text { secondary }\end{array}$ & ligação química & $\begin{array}{l}\text { Questionários: } \\
\text { quantitativo, En- } \\
\text { trevistas, Vídeo/ } \\
\text { Áudio }\end{array}$ & $\begin{array}{c}\text { Aula exposi- } \\
\text { tiva, Trabalho em } \\
\text { grupo, Grupo de } \\
\text { discussão }\end{array}$ & Interativo \\
\hline
\end{tabular}


Tabela 1S. Dados a partir dos quais se realizou o estudo (continuação)

\begin{tabular}{|c|c|c|c|c|c|c|c|c|c|}
\hline Ref. & Título & Autores & $\begin{array}{l}\text { País da } \\
\text { instituição } \\
\text { do } 1^{\circ} \text { autor }\end{array}$ & Tipo de artigo & Palavras-chave & $\begin{array}{l}\text { Conceitos } \\
\text { (até 2) }\end{array}$ & $\begin{array}{l}\text { Metodologia de } \\
\text { pesquisa (até 4) }\end{array}$ & $\begin{array}{c}\text { Metodologia } \\
\text { usada no contexto } \\
\text { educacional } \\
\text { (até 5) }\end{array}$ & $\begin{array}{c}\text { Meio } \\
\text { suporte } \\
\text { didático } 1 \\
\text { (até 3) }\end{array}$ \\
\hline $\begin{array}{l}\text { J. Res. Sci. Teach. } \\
\mathbf{2 0 1 0}, 47,91\end{array}$ & $\begin{array}{l}\text { Bridging Scientific Rea- } \\
\text { soning And Concep- } \\
\text { tual Change Through } \\
\text { Adaptive Web-Based } \\
\text { Learning }\end{array}$ & $\begin{array}{c}\text { She H C; Liao } \\
\text { Y W }\end{array}$ & Taiwan & Investigação & $\begin{array}{c}\text { chemistry; con- } \\
\text { ceptual change; } \\
\text { technology educa- } \\
\text { tion ; middle school } \\
\text { science } \\
\end{array}$ & $\begin{array}{l}\text { estrutura } \\
\text { atômica }\end{array}$ & $\begin{array}{l}\text { Pré/Pós-testes, } \\
\text { Entrevistas, } \\
\text { Vídeo/Áudio }\end{array}$ & $\begin{array}{l}\text { Trabalho indi- } \\
\text { vidual }\end{array}$ & $\begin{array}{l}\text { Interativo, } \\
\text { Ilustração } \\
\text { eletrônica }\end{array}$ \\
\hline $\begin{array}{l}\text { J. Sci. Educ. Tech- } \\
\text { nol. 2003, 12, } 277\end{array}$ & $\begin{array}{l}\text { Common Molecules: } \\
\text { Bringing Research } \\
\text { And Teaching Together } \\
\text { Through An Online } \\
\text { Collection }\end{array}$ & $\begin{array}{c}\text { Sandvoss L } \\
\text { M; Harwood } \\
\text { W S; Korkmaz } \\
\text { A; Bollinger } \\
\text { J C; Huffman } \\
\text { J C; Huffman } \\
\text { J N } \\
\end{array}$ & EUA & $\begin{array}{l}\text { Recurso } \\
\text { didático }\end{array}$ & $\begin{array}{l}\text { common molecules; } \\
\text { chemistry education; } \\
\text { visualization; digital } \\
\text { library; crystal } \\
\text { structures }\end{array}$ & $\begin{array}{l}\text { estrutura } \\
\text { molecular }\end{array}$ & Não citada & Não citada & Interativo \\
\hline $\begin{array}{l}\text { J. Sci. Educ. Tech- } \\
\text { nol. 2003, 12, } 285\end{array}$ & $\begin{array}{l}\text { Connected Chemis- } \\
\text { try-Incorporating } \\
\text { Interactive Simulations } \\
\text { Into The Chemistry } \\
\text { Classroom }\end{array}$ & $\begin{array}{c}\text { Stieff M; } \\
\text { Wilensky U }\end{array}$ & EUA & Metodologia & $\begin{array}{l}\text { chemistry education; } \\
\text { modeling environ- } \\
\text { ments; scientific } \\
\text { visualization }\end{array}$ & equilíbrio & $\begin{array}{l}\text { Entrevistas, } \\
\text { Questionários: } \\
\text { qualitativo }\end{array}$ & $\begin{array}{l}\text { Trabalho indi- } \\
\text { vidual }\end{array}$ & Interativo \\
\hline $\begin{array}{l}\text { J. Sci. Educ. Tech- } \\
\text { nol. 2004, 13, } 51\end{array}$ & $\begin{array}{l}\text { Reasoning With } \\
\text { Atomic-Scale Molecu- } \\
\text { lar Dynamic Models }\end{array}$ & $\begin{array}{l}\text { Pallant A; } \\
\text { Tinker R F }\end{array}$ & EUA & Metodologia & $\begin{array}{l}\text { models; phases of } \\
\text { matter; thermody- } \\
\text { namics; molecular } \\
\text { dynamics }\end{array}$ & $\begin{array}{l}\text { Natureza } \\
\text { particular da } \\
\text { matéria }\end{array}$ & $\begin{array}{l}\text { Questionários: } \\
\text { quantitativo, Ent- } \\
\text { revistas, Desenho }\end{array}$ & $\begin{array}{l}\text { Trabalho em } \\
\text { grupo }\end{array}$ & Interativo \\
\hline $\begin{array}{l}\text { J. Sci. Educ. Tech- } \\
\text { nol. 2004, 13, } 243\end{array}$ & $\begin{array}{l}\text { Web-Supported Chem- } \\
\text { istry Education: Design } \\
\text { Of An Online Tutorial } \\
\text { For Learning Molecular } \\
\text { Symmetry }\end{array}$ & $\begin{array}{l}\text { Korkmaz A; } \\
\text { Harwood W S }\end{array}$ & EUA & $\begin{array}{l}\text { Recurso } \\
\text { didático }\end{array}$ & $\begin{array}{l}\text { 3-D; symmetry; } \\
\text { interactivity; } \\
\text { molecular estructure; } \\
\text { inorganic chemistry }\end{array}$ & simetria & $\begin{array}{c}\text { Entrevistas, Pré/ } \\
\text { Pós-testes, Vídeo/ } \\
\text { Áudio }\end{array}$ & $\begin{array}{c}\text { Trabalho indi- } \\
\text { vidual }\end{array}$ & $\begin{array}{l}\text { Interativo, } \\
\text { Modelos } \\
\text { físicos, Il- } \\
\text { ustração em } \\
\text { papel } \\
\end{array}$ \\
\hline $\begin{array}{l}\text { J. Sci. Educ. Tech- } \\
\text { nol. 2004, 13, } 315\end{array}$ & $\begin{array}{l}\text { The Use Of Video } \\
\text { Demonstrations And } \\
\text { Particulate Animation } \\
\text { In General Chemistry }\end{array}$ & $\begin{array}{c}\text { Velázquez- } \\
\text { Marcano A; } \\
\text { Williamson V } \\
\text { M; Ashkenazi } \\
\text { G; Tasker R; } \\
\text { Williamson } \\
\text { K C }\end{array}$ & EUA & Investigação & $\begin{array}{c}\text { chemical education } \\
\text { research; particulate } \\
\text { nature of matter; } \\
\text { computer-based } \\
\text { instruction; demon- } \\
\text { strations; internet/ } \\
\text { web-based materials; } \\
\text { teaching/learning } \\
\text { aids }\end{array}$ & difusão/efusão & Pré/Pós-testes & $\begin{array}{l}\text { Trabalho indi- } \\
\text { vidual }\end{array}$ & Animação \\
\hline $\begin{array}{l}\text { J. Sci. Educ. Tech- } \\
\text { nol. 2004, 13, } 361\end{array}$ & $\begin{array}{l}\text { Instructional Technol- } \\
\text { ogy And Molecular } \\
\text { Visualization } \\
\end{array}$ & $\begin{array}{c}\text { Appling J } \\
\text { R;Peake L C }\end{array}$ & EUA & Metodologia & $\begin{array}{l}\text { multimedia; chemis- } \\
\text { try; model-building }\end{array}$ & $\begin{array}{l}\text { estrutura } \\
\text { molecular }\end{array}$ & Pré/Pós-testes & $\begin{array}{l}\text { Trabalho indi- } \\
\text { vidual }\end{array}$ & $\begin{array}{l}\text { Interativo, } \\
\text { Modelos } \\
\text { físicos } \\
\end{array}$ \\
\hline $\begin{array}{l}\text { J. Sci. Educ. Tech- } \\
\text { nol. 2004, 13, } 461\end{array}$ & $\begin{array}{l}\text { Students' Understand- } \\
\text { ing Is Enhanced } \\
\text { Through Molecular } \\
\text { Modeling }\end{array}$ & Ealy J B & EUA & Investigação & $\begin{array}{l}\text { molecular modeling; } \\
\text { multimedia learning; } \\
\text { microscopic }\end{array}$ & vários & Pré/Pós-testes & $\begin{array}{l}\text { Aula exposi- } \\
\text { tiva, Trabalho em } \\
\text { grupo, Grupo de } \\
\text { discussão, Trab- } \\
\text { alho individual }\end{array}$ & $\begin{array}{l}\text { Interativo, } \\
\text { Modelos } \\
\text { físicos, Il- } \\
\text { ustração } \\
\text { eletrônica } \\
\end{array}$ \\
\hline $\begin{array}{l}\text { J. Sci. Educ. Tech- } \\
\text { nol. 2005, } 14,51\end{array}$ & $\begin{array}{l}\text { The Effect Of Instruc- } \\
\text { tional Modality And } \\
\text { Prior Knowledge On } \\
\text { Learning Point Group } \\
\text { Symmetry }\end{array}$ & $\begin{array}{l}\text { Nottis K E K; } \\
\text { Kastner M E }\end{array}$ & EUA & Investigação & $\begin{array}{l}\text { chemistry educa- } \\
\text { tion; point group } \\
\text { symmetry; computer } \\
\text { courseware; prior } \\
\text { knowledge } \\
\end{array}$ & simetria & $\begin{array}{l}\text { Questionários: } \\
\text { quantitativo, Pré/ } \\
\text { Pós-testes, Vídeo/ } \\
\text { Áudio, Desenho }\end{array}$ & $\begin{array}{l}\text { Aula exposi- } \\
\text { tiva, Trabalho em } \\
\text { grupo, Trabalho } \\
\text { individual }\end{array}$ & $\begin{array}{l}\text { Interativo, } \\
\text { Modelos } \\
\text { físicos, Il- } \\
\text { ustração em } \\
\text { papel } \\
\end{array}$ \\
\hline $\begin{array}{l}\text { J. Sci. Educ. Tech- } \\
\text { nol. 2007, 16, } 413\end{array}$ & $\begin{array}{l}\text { Exploring How Dif- } \\
\text { ferent Features Of } \\
\text { Animations Of Sodium } \\
\text { Chloride Dissolution } \\
\text { Affect Students' Expla- } \\
\text { nations }\end{array}$ & $\begin{array}{l}\text { Kelly R M; } \\
\text { Jones L L }\end{array}$ & EUA & Metodologia & $\begin{array}{l}\mathrm{NaCl} \text { dissolu- } \\
\text { tion; animations; } \\
\text { written, oral and } \\
\text { drawn explanations; } \\
\text { misconceptions }\end{array}$ & $\begin{array}{l}\text { interações in- } \\
\text { termoleculares }\end{array}$ & $\begin{array}{l}\text { Vídeo/Áudio, } \\
\text { Entrevistas, } \\
\text { Questionários: } \\
\text { qualitativo }\end{array}$ & $\begin{array}{l}\text { Trabalho em } \\
\text { grupo, Grupo de } \\
\text { discussão, Trab- } \\
\text { alho individual }\end{array}$ & Animação \\
\hline $\begin{array}{l}\text { J. Sci. Educ. Tech- } \\
\text { nol. 2008, 17, } 49\end{array}$ & $\begin{array}{l}\text { Using A Computer } \\
\text { Animation To Teach } \\
\text { High School Molecular } \\
\text { Biology }\end{array}$ & $\begin{array}{l}\text { Rotbain Y; } \\
\text { Marbach-Ad } \\
\text { G; Stavy R }\end{array}$ & Israel & Investigação & $\begin{array}{c}\text { computer animation; } \\
\text { molecular genetics; } \\
\text { secondary science; } \\
\text { nucleic acid } \\
\end{array}$ & $\begin{array}{l}\text { ácidos nuclei- } \\
\cos \end{array}$ & $\begin{array}{l}\text { Pré/Pós-testes, } \\
\text { Entrevistas } \\
\text { Desenho }\end{array}$ & $\begin{array}{c}\text { Aula expositiva, } \\
\text { Trabalho indi- } \\
\text { vidual, Grupo de } \\
\text { discussão } \\
\end{array}$ & Interativo \\
\hline $\begin{array}{l}\text { J. Sci. Educ. Tech- } \\
\text { nol. 2008, 17, } 466\end{array}$ & $\begin{array}{l}\text { The Impact Of } \\
\text { Learner'S Prior Knowl- } \\
\text { edge On Their Use Of } \\
\text { Chemistry Computer } \\
\text { Simulations: A Case } \\
\text { Study }\end{array}$ & $\begin{array}{c}\text { Liu H C; } \\
\text { Andre T; } \\
\text { Greenbowe } \\
\text { T J }\end{array}$ & Taiwan & Investigação & $\begin{array}{l}\text { chemical education; } \\
\text { science education; } \\
\text { computer simula- } \\
\text { tion; computer- } \\
\text { supported learning }\end{array}$ & eletroquímica & $\begin{array}{l}\text { Vídeo/Áudio, } \\
\text { Pré/Pós-testes, } \\
\text { Questionários: } \\
\text { qualitativo }\end{array}$ & $\begin{array}{l}\text { Outros, Grupo de } \\
\text { discussão, Trab- } \\
\text { alho em grupo }\end{array}$ & Interativo \\
\hline $\begin{array}{l}\text { J. Sci. Educ. Tech- } \\
\text { nol. 2008, 17, } 305\end{array}$ & $\begin{array}{l}\text { The Effect Of A } \\
\text { Computerized Simula- } \\
\text { tion On Middle School } \\
\text { Students' Understand- } \\
\text { ing Of The Kinetic } \\
\text { Molecular Theory }\end{array}$ & $\begin{array}{l}\text { Stern L; } \\
\text { Barnea N; } \\
\text { Shauli S }\end{array}$ & EUA & Investigação & $\begin{array}{l}\text { dynamic } \\
\text { simulation;kinetic } \\
\text { molecular theory; } \\
\text { middle school; } \\
\text { teaching strategies; } \\
\text { curricular interven- } \\
\text { tion; particles; } \\
\text { miscroscopic view }\end{array}$ & $\begin{array}{l}\text { Natureza } \\
\text { particular da } \\
\text { matéria }\end{array}$ & $\begin{array}{l}\text { Questionários: } \\
\text { quantitativo, Ent- } \\
\text { revistas, Desenho }\end{array}$ & $\begin{array}{l}\text { Aula expositiva, } \\
\text { Trabalho indi- } \\
\text { vidual }\end{array}$ & Interativo \\
\hline PEC 2008, 9, 17 & $\begin{array}{l}\text { Images And Compu- } \\
\text { tational Methods In } \\
\text { Molecular Modeling } \\
\text { Education }\end{array}$ & $\begin{array}{c}\text { Arroio A; } \\
\text { Honório K M }\end{array}$ & Brasil & $\begin{array}{l}\text { Recurso } \\
\text { didático }\end{array}$ & $\begin{array}{l}\text { images; visualiza- } \\
\text { tion; computational } \\
\text { techniques; molecu- } \\
\text { lar modeling }\end{array}$ & $\begin{array}{l}\text { orbital molecu- } \\
\text { lar, proteínas }\end{array}$ & Não citada & Não citada & $\begin{array}{l}\text { Ilustração } \\
\text { eletrônica }\end{array}$ \\
\hline
\end{tabular}


Tabela 1S. Dados a partir dos quais se realizou o estudo (continuação)

\begin{tabular}{|c|c|c|c|c|c|c|c|c|c|}
\hline Ref. & Título & Autores & $\begin{array}{c}\text { País da } \\
\text { instituição } \\
\text { do } 1^{\circ} \text { autor }\end{array}$ & Tipo de artigo & Palavras-chave & $\begin{array}{c}\text { Conceitos } \\
\text { (até 2) }\end{array}$ & $\begin{array}{l}\text { Metodologia de } \\
\text { pesquisa (até 4) }\end{array}$ & $\begin{array}{c}\text { Metodologia } \\
\text { usada no contexto } \\
\text { educacional } \\
\text { (até 5) }\end{array}$ & $\begin{array}{c}\text { Meio } \\
\text { suporte } \\
\text { didático } 1 \\
\text { (até 3) }\end{array}$ \\
\hline PEC 2009, 11, 69 & $\begin{array}{l}\text { Teaching Protein Sci- } \\
\text { ence With Application } \\
\text { Of Computers - Case } \\
\text { Study Of Bcl-2 Protein } \\
\text { Family }\end{array}$ & $\begin{array}{c}\text { Kaczor A; } \\
\text { Matosiuk D; } \\
\text { Persona A }\end{array}$ & Polônia & Metodologia & $\begin{array}{c}\text { protein science; } \\
\text { proteins as drug tar- } \\
\text { gets; BCL-2 protein } \\
\text { family }\end{array}$ & proteínas & Não citada & $\begin{array}{c}\text { Outros, Aula } \\
\text { expositiva }\end{array}$ & Interativo \\
\hline PEC 2009, 16, 23 & $\begin{array}{l}\text { Visualization InScience } \\
\text { Education: The Results } \\
\text { Of Pilot Research In } \\
\text { Grade } 10\end{array}$ & Bilbokaité R & Lituânia & Investigação & $\begin{array}{l}\text { science education; } \\
\text { visualization }\end{array}$ & $\begin{array}{l}\text { Não espe- } \\
\text { cificado }\end{array}$ & $\begin{array}{l}\text { Pré/Pós-testes, } \\
\text { Likert }\end{array}$ & Outros & $\begin{array}{l}\text { Ilustração } \\
\text { em papel, } \\
\text { Ilustração } \\
\text { eletrônica }\end{array}$ \\
\hline PEC 2009, 16, 48 & $\begin{array}{l}\text { Teacher'S Education } \\
\text { And The Use Of Visu- } \\
\text { alizations In Chemistry } \\
\text { Instruction }\end{array}$ & $\begin{array}{c}\text { Ferreira C; } \\
\text { Arroio A }\end{array}$ & Brasil & Investigação & $\begin{array}{l}\text { visualization; chem- } \\
\text { istry instructing; } \\
\text { teacher's formation }\end{array}$ & $\begin{array}{l}\text { Não espe- } \\
\text { cificado }\end{array}$ & $\begin{array}{c}\text { Questionários: } \\
\text { qualitativo }\end{array}$ & Outros & Outros \\
\hline PEC 2009, 16,80 & $\begin{array}{l}\text { Chemistry Teachers' } \\
\text { And Student'S Percep- } \\
\text { tions Of Practical Work } \\
\text { Trhough Different Ict } \\
\text { Learning Environments }\end{array}$ & $\begin{array}{l}\text { Pernaa J; } \\
\text { Aksela M }\end{array}$ & Finlândia & Investigação & $\begin{array}{l}\text { chemistry teaching; } \\
\text { information and } \\
\text { communications } \\
\text { technology; ICT; } \\
\text { modeling; practical } \\
\text { work } \\
\end{array}$ & vários & $\begin{array}{c}\text { Likert, Question- } \\
\text { ários: qualitativo, } \\
\text { Pré/Pós-testes }\end{array}$ & $\begin{array}{l}\text { Outros, Trabalho } \\
\text { em grupo, Outros }\end{array}$ & $\begin{array}{c}\text { Animação, } \\
\text { Interativo }\end{array}$ \\
\hline PEC 2010, 24, 19 & $\begin{array}{l}\text { The Usage Of A } \\
\text { Simulation To Study } \\
\text { Intermolecular Forces: } \\
\text { Some Findings }\end{array}$ & $\begin{array}{l}\text { Ayres C; } \\
\text { Ferreira C; } \\
\text { Arroio A }\end{array}$ & Brasil & Metodologia & $\begin{array}{l}\text { visualization; com- } \\
\text { puter; simulation; } \\
\text { chemistry }\end{array}$ & $\begin{array}{l}\text { interações in- } \\
\text { termoleculares }\end{array}$ & $\begin{array}{l}\text { Questionários: } \\
\text { qualitativo, De- } \\
\text { senho }\end{array}$ & $\begin{array}{l}\text { Trabalho em } \\
\text { grupo }\end{array}$ & Interativo \\
\hline PEC 2010, 24, 49 & $\begin{array}{l}\text { Use Of Visualization To } \\
\text { Motivate Science And } \\
\text { Geography Education } \\
\text { Of Female School- } \\
\text { children }\end{array}$ & Bilbokaité R & Lituânia & Investigação & $\begin{array}{l}\text { visualization; moti- } \\
\text { vation; comprehen- } \\
\text { sive school }\end{array}$ & $\begin{array}{l}\text { Não espe- } \\
\text { cificado }\end{array}$ & Likert & Outros & Outros \\
\hline PEC 2010, 24, 75 & $\begin{array}{l}\text { Metavisualization: An } \\
\text { Important Skill In The } \\
\text { Learning Chemistry }\end{array}$ & $\begin{array}{l}\text { Locatelli S; } \\
\text { Ferreira C; } \\
\text { Arroio A }\end{array}$ & Brasil & Revisão & $\begin{array}{l}\text { metavisualization; } \\
\text { metacognition; visu- } \\
\text { alization; chemistry } \\
\text { instruction }\end{array}$ & $\begin{array}{l}\text { Não espe- } \\
\text { cificado }\end{array}$ & Outros & Outros & Outros \\
\hline QN 2004, 27, 489 & $\begin{array}{l}\text { Ampc - Sinalização In- } \\
\text { tracelular: Um Software } \\
\text { Educacional }\end{array}$ & $\begin{array}{c}\text { Yokaichiya D } \\
\text { K; Fraceto L } \\
\text { F; Miranda M } \\
\text { A; Galembeck } \\
\text { E; Torres B B }\end{array}$ & Brasil & Metodologia & $\begin{array}{l}\text { AMPc; educational } \\
\text { software; intracelu- } \\
\text { lar signaling }\end{array}$ & $\begin{array}{l}\text { sinalização } \\
\text { celular }\end{array}$ & $\begin{array}{l}\text { Likert, Question- } \\
\text { ários: qualitativo }\end{array}$ & $\begin{array}{l}\text { Outros, Trabalho } \\
\text { em grupo }\end{array}$ & Interativo \\
\hline QN 2005, 28, 360 & $\begin{array}{l}\text { O Ensino De Química } \\
\text { Quântica E O Computa- } \\
\text { dor Na Perspectiva De } \\
\text { Projetos }\end{array}$ & $\begin{array}{c}\text { Arroio A; } \\
\text { Honório K M; } \\
\text { Weber K C; } \\
\text { Mello P M; } \\
\text { Silva A B F }\end{array}$ & Brasil & Metodologia & $\begin{array}{l}\text { computer; projects; } \\
\text { quantum chemistry } \\
\text { teaching }\end{array}$ & $\begin{array}{l}\text { estrutura } \\
\text { molecular }\end{array}$ & $\begin{array}{l}\text { Seminários, } \\
\text { Questionários: } \\
\text { qualitativo }\end{array}$ & $\begin{array}{l}\text { Outros, Trabalho } \\
\text { em grupo, Aula } \\
\text { expositiva }\end{array}$ & Interativo \\
\hline QN 2007, 30, 727 & $\begin{array}{l}\text { Reatividade Em } \\
\text { Reações De Diels- } \\
\text { Alder: Uma Prática } \\
\text { Computacional }\end{array}$ & $\begin{array}{c}\text { Lacerda Jr } \\
\text { V; Oliveira K } \\
\text { T; Silva R C } \\
\text { Constantino } \\
\text { M G; Silva } \\
\text { G V J } \\
\end{array}$ & Brasil & $\begin{array}{l}\text { Recurso } \\
\text { didático }\end{array}$ & $\begin{array}{l}\text { Diels-Alder reactiv- } \\
\text { ity; FMO theory; } \\
\text { NBO analysis }\end{array}$ & reações & Não citada & $\begin{array}{c}\text { Aula exposi- } \\
\text { tiva, Trabalho em } \\
\text { grupo }\end{array}$ & Interativo \\
\hline QN 2008, 31, 2184 & $\begin{array}{l}\text { Integración De } \\
\text { Visualización Científica } \\
\text { Molecular En El Salón } \\
\text { De Clases }\end{array}$ & $\begin{array}{c}\text { Gárcia-Ruiz } \\
\text { M A; Valdez- } \\
\text { Velasquez L } \\
\text { L; Gómes- } \\
\text { Sandoval Z }\end{array}$ & México & Metodologia & $\begin{array}{l}\text { molecular; visualiza- } \\
\text { tion; classroom }\end{array}$ & $\begin{array}{l}\text { estrutura } \\
\text { molecular }\end{array}$ & $\begin{array}{l}\text { Likert, Question- } \\
\text { ários: qualitativo }\end{array}$ & $\begin{array}{l}\text { Outros, Trabalho } \\
\text { em grupo }\end{array}$ & Interativo \\
\hline $\begin{array}{l}\text { QNESC 2009, } \\
31,82\end{array}$ & $\begin{array}{l}\text { Um Modelo Para O } \\
\text { Estudo Do Fenômeno } \\
\text { De Deposição Metálica } \\
\text { E Conceitos Afins }\end{array}$ & $\begin{array}{c}\text { Francisco } \\
\text { Júnior W E; } \\
\text { Ferreira L H; } \\
\text { Hartwig D R } \\
\end{array}$ & Brasil & Metodologia & $\begin{array}{l}\text { models; represen- } \\
\text { tation; metallic } \\
\text { deposition }\end{array}$ & eletroquímica & $\begin{array}{c}\text { Questionários: } \\
\text { qualitativo }\end{array}$ & $\begin{array}{l}\text { Trabalho indi- } \\
\text { vidual }\end{array}$ & $\begin{array}{l}\text { Modelos } \\
\text { físicos }\end{array}$ \\
\hline RBPEC 2003, 3, 58 & $\begin{array}{l}\text { Uso Do Software } \\
\text { Dicewin Na Química } \\
\text { Geral (The Use Of The } \\
\text { Dicewin Software In } \\
\text { General Chemistry }\end{array}$ & $\begin{array}{c}\text { Santos F M } \\
\text { T; Greca I M; } \\
\text { Serrano A }\end{array}$ & Brasil & Metodologia & $\begin{array}{c}\text { simulation programs; } \\
\text { general chemistry; } \\
\text { intermolecular } \\
\text { forces; chemistry } \\
\text { representations } \\
\end{array}$ & $\begin{array}{l}\text { interações in- } \\
\text { termoleculares }\end{array}$ & Desenho & $\begin{array}{c}\text { Aula exposi- } \\
\text { tiva, Trabalho em } \\
\text { grupo }\end{array}$ & Interativo \\
\hline REEC 2005, 4 & $\begin{array}{l}\text { Promovendo Apren- } \\
\text { dizagem De Conceitos } \\
\text { E De Representações } \\
\text { Pictóricas Em Química } \\
\text { Com Uma Ferramenta } \\
\text { De Simulação Com- } \\
\text { putacional }\end{array}$ & $\begin{array}{l}\text { Santos F M T; } \\
\text { Greca I M }\end{array}$ & Brasil & Investigação & $\begin{array}{l}\text { chemistry concepts; } \\
\text { pictorial representa- } \\
\text { tions; simulations }\end{array}$ & $\begin{array}{l}\text { interações in- } \\
\text { termoleculares }\end{array}$ & $\begin{array}{c}\text { Desenho, Vídeo/ } \\
\text { Áudio }\end{array}$ & $\begin{array}{l}\text { Trabalho } \\
\text { individual, Aula } \\
\text { expositiva }\end{array}$ & Interativo \\
\hline REEC 2008, 7, 629 & $\begin{array}{l}\text { Modelar La Naturaleza } \\
\text { Discontinua De La Ma- } \\
\text { teria: Una Propuesta } \\
\text { Para La Escuela Media }\end{array}$ & $\begin{array}{c}\text { Giudice J; } \\
\text { Galagovsky L }\end{array}$ & Argentina & Investigação & $\begin{array}{c}\text { teaching; learning; } \\
\text { model; analogy; } \\
\text { particulate nature of } \\
\text { matter }\end{array}$ & $\begin{array}{l}\text { Natureza } \\
\text { particular da } \\
\text { matéria }\end{array}$ & $\begin{array}{l}\text { Desenho, } \\
\text { Questionários: } \\
\text { quantitativo }\end{array}$ & $\begin{array}{l}\text { Aula expositiva, } \\
\text { Trabalho em lab- } \\
\text { oratório, Trabalho } \\
\text { individual, Grupo } \\
\quad \text { de discussão }\end{array}$ & $\begin{array}{l}\text { Ilustração } \\
\text { eletrônica }\end{array}$ \\
\hline
\end{tabular}


Tabela 1S. Dados a partir dos quais se realizou o estudo (continuação)

\begin{tabular}{|c|c|c|c|c|c|c|c|c|c|}
\hline Ref. & Título & Autores & $\begin{array}{l}\text { País da } \\
\text { instituição } \\
\text { do } 1^{\circ} \text { autor }\end{array}$ & Tipo de artigo & Palavras-chave & $\begin{array}{l}\text { Conceitos } \\
\text { (até 2) }\end{array}$ & $\begin{array}{l}\text { Metodologia de } \\
\text { pesquisa (até 4) }\end{array}$ & $\begin{array}{c}\text { Metodologia } \\
\text { usada no contexto } \\
\text { educacional } \\
\text { (até 5) }\end{array}$ & $\begin{array}{c}\text { Meio } \\
\text { suporte } \\
\text { didático } 1 \\
\text { (até 3) }\end{array}$ \\
\hline REEC 2009, 8, 440 & $\begin{array}{l}\text { Integración De Elemen- } \\
\text { tos Didácticos Y Del } \\
\text { Diseño Em El Software } \\
\text { Educativo Hiperme- } \\
\text { dial "Estequiometría. } \\
\text { Contando Masas, Moles } \\
\text { Y Partículas" }\end{array}$ & $\begin{array}{l}\text { Grisolia M; } \\
\text { Grisolia C V }\end{array}$ & Venezuela & $\begin{array}{l}\text { Recurso } \\
\text { didático }\end{array}$ & $\begin{array}{l}\text { educational } \\
\text { software; graphic de- } \\
\text { sign; stoichiometry; } \\
\text { chemistry teaching } \\
\text { and learninf }\end{array}$ & estequiometria & $\begin{array}{l}\text { Entrevistas, Mapa } \\
\text { conceitual }\end{array}$ & $\begin{array}{l}\text { Grupo de dis- } \\
\text { cussão, Trabalho } \\
\text { em grupo }\end{array}$ & Interativo \\
\hline REEC 2010, 9, 18 & $\begin{array}{l}\text { Uso De Um Software } \\
\text { De Construção De } \\
\text { Modelos Moleculares } \\
\text { No Ensino De Isomeria } \\
\text { Geométrica: Um Estudo } \\
\text { De Caso Baseado Na } \\
\text { Teoria De Mediação } \\
\text { Cognitiva }\end{array}$ & $\begin{array}{c}\text { Raupp D; } \\
\text { Serrano A; } \\
\text { Martins T L } \\
\text { C; Souza B C }\end{array}$ & Brasil & Metodologia & $\begin{array}{l}\text { computer simula- } \\
\text { tions; isomers; } \\
\text { theories of cognition } \\
\text { and learning; repre- } \\
\text { sentations }\end{array}$ & isomeria & $\begin{array}{l}\text { Desenho, } \\
\text { Questionários: } \\
\text { quantitativo }\end{array}$ & $\begin{array}{l}\text { Aula expositiva, } \\
\text { Trabalho indi- } \\
\text { vidual }\end{array}$ & Interativo \\
\hline $\begin{array}{l}\text { Res. Sci. Educ. } \\
\text { 2004, } 34,1\end{array}$ & $\begin{array}{l}\text { Students' Understand- } \\
\text { ing Of The Descriptive } \\
\text { And Predictive Nature } \\
\text { Of Teaching Models In } \\
\text { Organic Chemistry }\end{array}$ & $\begin{array}{c}\text { Treagust D F; } \\
\text { Chittleborough } \\
\text { G D; Mamiala } \\
\text { T L }\end{array}$ & Austrália & Metodologia & $\begin{array}{l}\text { mental models; } \\
\text { organic chemistry; } \\
\text { scientific models; } \\
\text { teaching model; } \\
\text { uppersecondary } \\
\text { science } \\
\end{array}$ & $\begin{array}{l}\text { estrutura } \\
\text { molecular }\end{array}$ & $\begin{array}{l}\text { Likert, Vídeo/Áu- } \\
\text { dio, Entrevistas, }\end{array}$ & $\begin{array}{l}\text { Aula exposi- } \\
\text { tiva, Trabalho em } \\
\text { grupo, Grupo de } \\
\text { discussão }\end{array}$ & $\begin{array}{l}\text { Interativo, } \\
\text { Modelos } \\
\text { físicos, Il- } \\
\text { ustração em } \\
\text { papel }\end{array}$ \\
\hline $\begin{array}{l}\text { Res. Sci. Educ. } \\
\text { 2008, } 38,463\end{array}$ & $\begin{array}{l}\text { Correct Interpretation } \\
\text { Of Chemical Diagrams } \\
\text { Requires Transform- } \\
\text { ing From One Level } \\
\text { Of Representation To } \\
\text { Another }\end{array}$ & $\begin{array}{l}\text { Chittleborough } \\
\text { G; Treagust D }\end{array}$ & Austrália & Metodologia & $\begin{array}{l}\text { chemical diagrams; } \\
\text { chemistry; represen- } \\
\text { tations; explana- } \\
\text { tions; non-major; } \\
\text { first-year university }\end{array}$ & vários & $\begin{array}{l}\text { Questionários: } \\
\text { quantitativo, } \\
\text { Pré/Pós-testes, } \\
\text { Entrevistas }\end{array}$ & $\begin{array}{l}\text { Trabalho indi- } \\
\text { vidual, Outros }\end{array}$ & $\begin{array}{l}\text { Ilustração } \\
\text { eletrônica, } \\
\text { Ilustração } \\
\text { eletrônica }\end{array}$ \\
\hline $\begin{array}{l}\text { Res. Sci. Educ. } \\
\text { 2009, 39, } 495\end{array}$ & $\begin{array}{l}\text { The Effect Of } \\
\text { Three-Dimensional } \\
\text { Simulations On The } \\
\text { Understanding Of } \\
\text { Chemical Structures } \\
\text { And Their Properties }\end{array}$ & $\begin{array}{l}\text { Urhahne } \\
\text { D; Nick S; } \\
\text { Schanze S }\end{array}$ & Alemanha & Investigação & $\begin{array}{l}\text { three dimensional } \\
\text { simulations; infor- } \\
\text { mation technology; } \\
\text { conceptual knowl- } \\
\text { edge; spatial ability; } \\
\text { chemistry education }\end{array}$ & $\begin{array}{l}\text { estrutura } \\
\text { molecular }\end{array}$ & $\begin{array}{l}\text { Likert, Pré/Pós- } \\
\text { testes, Desenho }\end{array}$ & $\begin{array}{l}\text { Trabalho indi- } \\
\text { vidual, Trabalho } \\
\text { em grupo }\end{array}$ & $\begin{array}{l}\text { Interativo, } \\
\text { Ilustração } \\
\text { eletrônica }\end{array}$ \\
\hline $\begin{array}{l}\text { Res. Sci. Educ. } \\
\mathbf{2 0 1 0}, 40,375\end{array}$ & $\begin{array}{l}\text { Learning Using } \\
\text { Dynamic And Static } \\
\text { Visualizations: Stu- } \\
\text { dents' Comprehension, } \\
\text { Prior Knowledge And } \\
\text { Conceptual Status Of } \\
\text { A Biotechnological } \\
\text { Method }\end{array}$ & $\begin{array}{l}\text { Yarden } \mathrm{H} \text {; } \\
\text { Yarden A }\end{array}$ & Israel & Investigação & $\begin{array}{c}\text { animations; } \\
\text { biotechnology } \\
\text { education; concep- } \\
\text { tual status; dynamic } \\
\text { visualization; prior } \\
\text { knowledge; static } \\
\text { visualization }\end{array}$ & PCR, & $\begin{array}{l}\text { Pré/Pós-testes, } \\
\text { Questionários: } \\
\text { quantitativo, } \\
\text { Vídeo/Áudio }\end{array}$ & $\begin{array}{l}\text { Aula expositiva, } \\
\text { Trabalho indi- } \\
\text { vidual, Trabalho } \\
\text { em grupo, Grupo } \\
\text { de discussão }\end{array}$ & $\begin{array}{l}\text { Interativo, } \\
\text { Ilustração } \\
\text { eletrônica }\end{array}$ \\
\hline $\begin{array}{l}\text { Sci. Edu. 2003, } \\
87,794\end{array}$ & $\begin{array}{l}\text { Linking Phenom- } \\
\text { ena With Competing } \\
\text { Underlying Models: } \\
\text { A Software Tool For } \\
\text { Introducing Students To } \\
\text { The Particulate Model } \\
\text { Of Matter }\end{array}$ & $\begin{array}{l}\text { Snir J; Smith } \\
\text { C L; Raz G }\end{array}$ & Israel & Investigação & Não citadas & $\begin{array}{l}\text { Natureza } \\
\text { particular da } \\
\text { matéria, }\end{array}$ & $\begin{array}{l}\text { Pré/Pós-testes, } \\
\text { Entrevistas }\end{array}$ & $\begin{array}{l}\text { Trabalho indi- } \\
\text { vidual }\end{array}$ & Interativo \\
\hline $\begin{array}{l}\text { Sci. Edu. 2004, } \\
88,465\end{array}$ & $\begin{array}{l}\text { Exploring Visuospatial } \\
\text { Thinking In Chemistry } \\
\text { Learning }\end{array}$ & $\begin{array}{l}\text { Hu H K; } \\
\text { Shah P }\end{array}$ & Taiwan & Revisão & Não citadas & $\begin{array}{l}\text { Não espe- } \\
\text { cificado }\end{array}$ & Outros & Outros & Outros \\
\hline $\begin{array}{l}\text { Sci. Edu. 2005, } \\
89,117\end{array}$ & $\begin{array}{l}\text { Enhancing Undergradu- } \\
\text { ate Students' Chemistry } \\
\text { Understanding Through } \\
\text { Project-Based Learning } \\
\text { In An It Environment }\end{array}$ & $\begin{array}{c}\text { Barak M; Dori } \\
\text { Y J }\end{array}$ & EUA & Investigação & Não citadas & vários & $\begin{array}{l}\text { Pré/Pós-testes, } \\
\text { Likert, Entrev- } \\
\quad \text { istas }\end{array}$ & $\begin{array}{l}\text { Outros, Trabalho } \\
\text { individual }\end{array}$ & Interativo \\
\hline $\begin{array}{l}\text { Sci. Edu. 2006, 90, } \\
1073\end{array}$ & $\begin{array}{l}\text { Visual Representations } \\
\text { In Science Educa- } \\
\text { tion: The Influence Of } \\
\text { Prior Knowledge And } \\
\text { Cognitive Load Theory } \\
\text { On Instructional Design } \\
\text { Principles }\end{array}$ & Cook M P & EUA & Revisão & Não citadas & $\begin{array}{l}\text { Não espe- } \\
\text { cificado }\end{array}$ & Outros & Outros & Outros \\
\hline $\begin{array}{l}\text { Sci. Edu. 2008, } \\
92,848\end{array}$ & $\begin{array}{l}\text { The Influence Of Prior } \\
\text { Knowledge On View- } \\
\text { ing And Interpreting } \\
\text { Graphics With Macro- } \\
\text { scopic And Molecular } \\
\text { Representations }\end{array}$ & $\begin{array}{l}\text { Cook M; } \\
\text { Wiebe E N; } \\
\text { Carter G }\end{array}$ & EUA & Investigação & Não citadas & $\begin{array}{l}\text { transporte } \\
\text { celular }\end{array}$ & $\begin{array}{l}\text { Pré/Pós-testes, } \\
\text { Entrevistas }\end{array}$ & $\begin{array}{l}\text { Trabalho indi- } \\
\text { vidual }\end{array}$ & $\begin{array}{l}\text { Ilustração } \\
\text { eletrônica }\end{array}$ \\
\hline $\begin{array}{l}\text { Sci. Edu. 2010, } \\
94,73\end{array}$ & $\begin{array}{l}\text { The Impact Of Design- } \\
\text { ing And Evaluating } \\
\text { Molecular Animations } \\
\text { On How Well Middle } \\
\text { School Students Under- } \\
\text { stand The Particulate } \\
\text { Nature Of Matter }\end{array}$ & $\begin{array}{l}\text { Chang H Y; } \\
\text { Quintana C; } \\
\text { Krajcik J S }\end{array}$ & Taiwan & Investigação & Não citadas & $\begin{array}{l}\text { Natureza } \\
\text { particular da } \\
\text { matéria }\end{array}$ & $\begin{array}{c}\text { Pré/Pós-testes, } \\
\text { Questionários: } \\
\text { quantitativo, } \\
\text { Entrevistas }\end{array}$ & $\begin{array}{l}\text { Trabalho indi- } \\
\text { vidual }\end{array}$ & Interativo \\
\hline
\end{tabular}

